\title{
Rwanda: Third Review Under the Three-Year Arrangement Under the Poverty Reduction and Growth Facility and Request for Waiver of Nonobservance of Performance Criterion-Staff Report; Staff Supplement; Press Release on the Executive Board Discussion; and Statement by the Executive Director for Rwanda
}

In the context of the third review under the three-year arrangement under the Poverty Reduction and Growth Facility and a request for a waiver of nonobservance of a performance criterion, the following documents have been released and are included in this package:

- $\quad$ The staff report for the Third Review Under the Three-Year Arrangement Under the Poverty Reduction and Growth Facility and Request for Waiver of Nonobservance of Performance Criterion, prepared by a staff team of the IMF, following discussions that ended on December 11, 2007, with the officials of Rwanda on economic developments and policies. Based on information available at the time of these discussions, the staff report was completed on February 13, 2008. The views expressed in the staff report are those of the staff team and do not necessarily reflect the views of the Executive Board of the IMF.

- $\quad$ A staff supplement on the joint IMF/World Bank debt sustainability analysis.

- $\quad$ A Press Release summarizing the views of the Executive Board as expressed during its February 29, 2008 discussion of the staff report that completed the review.

- $\quad$ A statement by the Executive Director for Rwanda.

The documents listed below have been or will be separately released.

Letter of Intent sent to the IMF by the authorities of Rwanda* Memorandum of Economic and Financial Policies by the authorities of Rwanda* Technical Memorandum of Understanding* Poverty Reduction Strategy Paper Joint Staff Advisory Note of the Poverty Reduction Strategy Paper

*Also included in Staff Report

The policy of publication of staff reports and other documents allows for the deletion of market-sensitive information.

To assist the IMF in evaluating the publication policy, reader comments are invited and may be sent by e-mail to publicationpolicy@imf.org.

Copies of this report are available to the public from

International Monetary Fund • Publication Services

$70019^{\text {th }}$ Street, N.W. • Washington, D.C. 20431

Telephone: (202) 623-7430 • Telefax: (202) 623-7201

E-mail: publications@imf.org •Internet: http://www.imf.org

Price: $\$ 18.00$ a copy

International Monetary Fund

Washington, D.C. 

INTERNATIONAL MONETARY FUND

RWANDA

Third Review Under the Three-Year Arrangement Under the Poverty Reduction and Growth Facility and Request for Waiver of Nonobservance of Performance Criterion

Prepared by the African Department

(In collaboration with other departments)

Approved by Hugh Bredenkamp and Mark Plant

February 13, 2008

\section{Program Review}

- $\quad$ This report recommends completion of the third review under the PRGF arrangement based on Rwanda's performance and on understandings reached on the macroeconomic and structural program for 2008.

- All quantitative performance criteria for end-June 2007 were met. Staff supports the authorities' request for a waiver of nonobservance of an end-July 2007 structural performance criterion.

- The authorities' updated program is based on their new PRSP, covering 200812 .

\section{Participants}

- $\quad$ The mission (November 28-December 11, 2007) comprised Ms. Murgasova (head), Mr. Mitchell, Mr. Darius, and Ms. Kaendera (all AFR) and was assisted by Mr. Engström, the resident representative.

- $\quad$ The mission met with Minister of Finance and Economic Planning Musoni, Governor Kanimba of the National Bank of Rwanda, other government officials, and representatives of the private sector and the international community. 


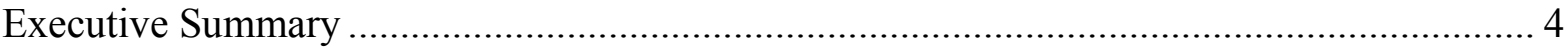

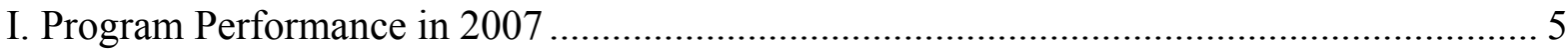

II. 2008 Program-Making Headway on the Medium-Term Agenda .................................. 9

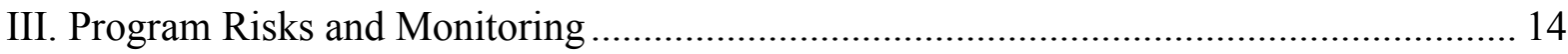

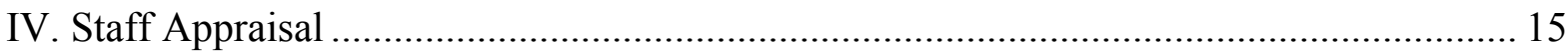

\section{Boxes}

1. Revised National Accounts ................................................................................... . 6

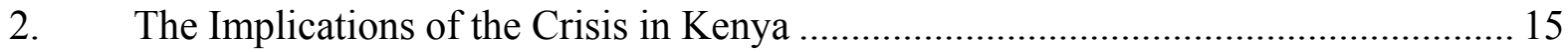

Figures

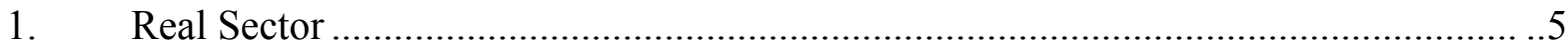

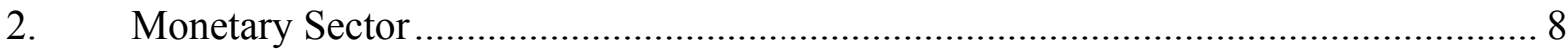

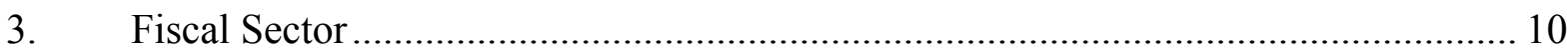

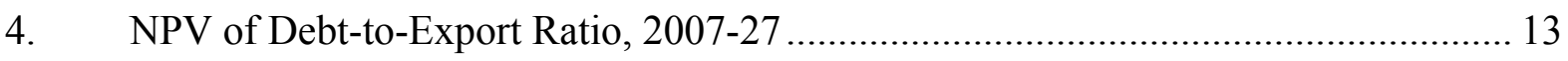

Tables

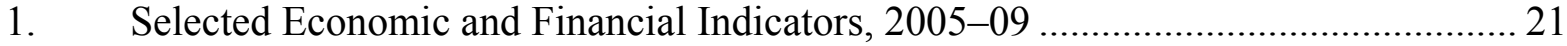

2. Operations of the Central Government, 2005-09 ..................................................... 22

3. Monetary Survey, 2005-08 …......................................................................... 24

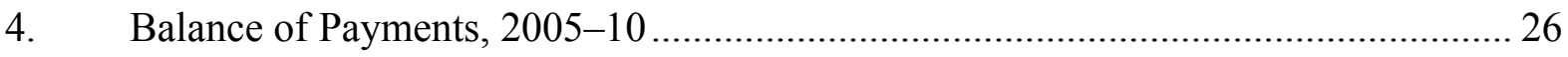

5. Key Economic Variables as a Percentage of Revised and Old GDP ........................ 27

6. National Accounts-Sector Composition, 2001-2007 …......................................... 28

7. Proposed Schedule of Disbursements under the PRGF Arrangement, 2008-09 ....... 29 
Appendices

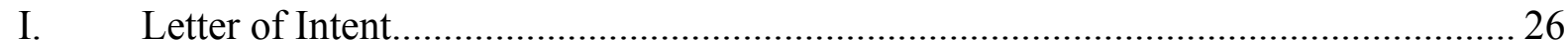

Attachment I. Memorandum of Economic and Financial Policies of the Government of Rwanda (2008) ............................................................ 28

Attachment II. Technical Memorandum of Understanding .............................. 46

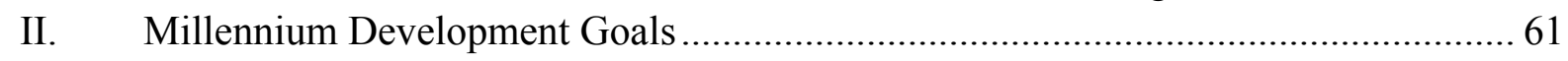




\section{EXECUTIVE SUMMARY}

Program performance has been satisfactory. Growth in 2007 accelerated to 6 percent, and inflationary pressures that emerged in the beginning of the year subsided. All end-June 2007 quantitative performance criteria and indicative targets were met, although delays in disbursements of donor funds until the fourth quarter caused the end-September fiscal indicative targets to be breached. Structural reforms advanced, albeit with some delays. The authorities are requesting a waiver for one delayed structural performance criterion.

The new PRSP, launched in late 2007, sets out the medium-term policy agenda. The focus will be on reducing poverty by preserving macroeconomic stability and removing impediments to growth, including through efforts to sustain the momentum in the social sectors, ease infrastructure bottlenecks, and modernize agriculture.

The 2008 program aims to sustain rapid growth and single digit inflation, while accommodating further scaling up of aid. Spending increases will focus on public infrastructure investment in priority sectors. Revenues are projected to increase as a share of GDP to reduce aid-dependence over the long term. Monetary policy will need to respond promptly should inflationary pressures reemerge.

The authorities are launching a few large projects in energy, agriculture, and information and telecommunication sectors aimed at easing binding infrastructure bottlenecks. Substantial external borrowing would be required for financing of these projects, despite scaling up of aid. To prevent the reaccumulation of unsustainable debt, the authorities will develop a debt management strategy to guide future borrowing.

The structural agenda focuses on maintaining the momentum in the previously initiated areas, particularly in the financial sector, tax administration and public financial management.

The main risk to the program is that inflationary pressures reemerge due to improper management of the scaling up of aid and fiscal spending, or a protracted crisis in Kenya. 


\section{Program Performance in 2007}

1. Economic activity has been robust, and initial inflationary pressures have abated. Real GDP growth is projected to reach 6 percent in 2007, exceeding expectations, reflecting healthy activity in construction and services (Figure 1 and Table 1). Inflation declined to 8.7 percent by November from a peak of 12 percent at end-2006, largely due to the moderation of food price inflation. Core inflation (excluding food and energy) increased in early 2007 because of administrative price adjustments, but has subsided since mid-year. Inflation is expected to exceed the original target of 5 percent, but remain in single digits by end-year.

Figure 1. Rwanda: Real Sector

Growth is strong...

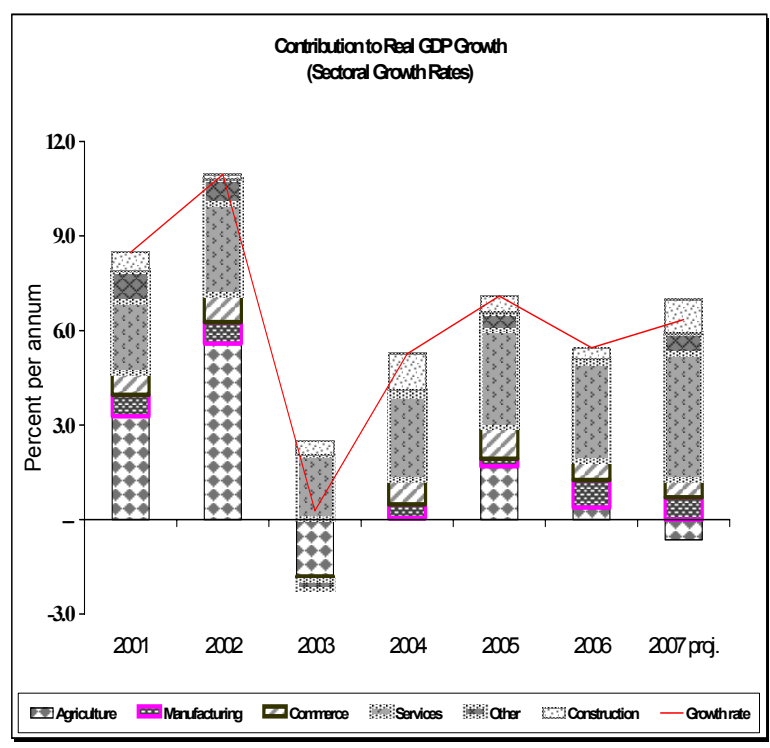

... and inflation has decelerated.

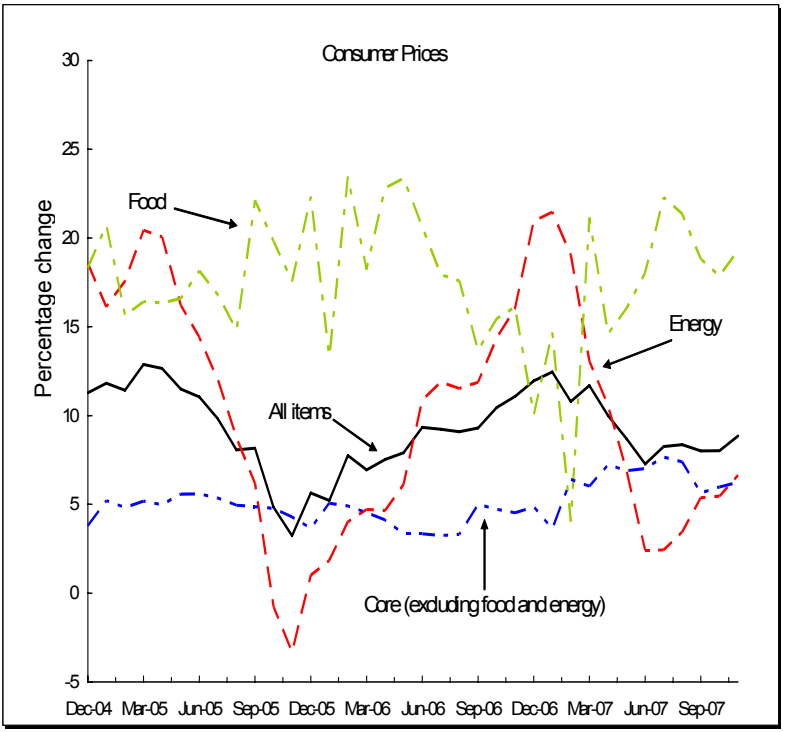

Source: Rwandan authorities and IMF staff estimates and projections. 


\section{Box 1. Revised National Accounts}

Rwanda's GDP series were reestimated from 1990 based on (i) more recent survey data and (ii) improved compilation methods, which are more closely in line with the United Nations 1993 systems of national accounts. The key changes include greater coverage of informal sector activities and the emergence of the services sector as the leading contributor to output, replacing the agricultural sector. The underlying methodology and statistical tables were reviewed and approved by the IMF's Statistics Department. The new level and growth rate of nominal GDP are higher from 2003 onwards and ratios of economic variables are lower compared to those reported in the previous Staff Reports (see Tables 5 and 6).

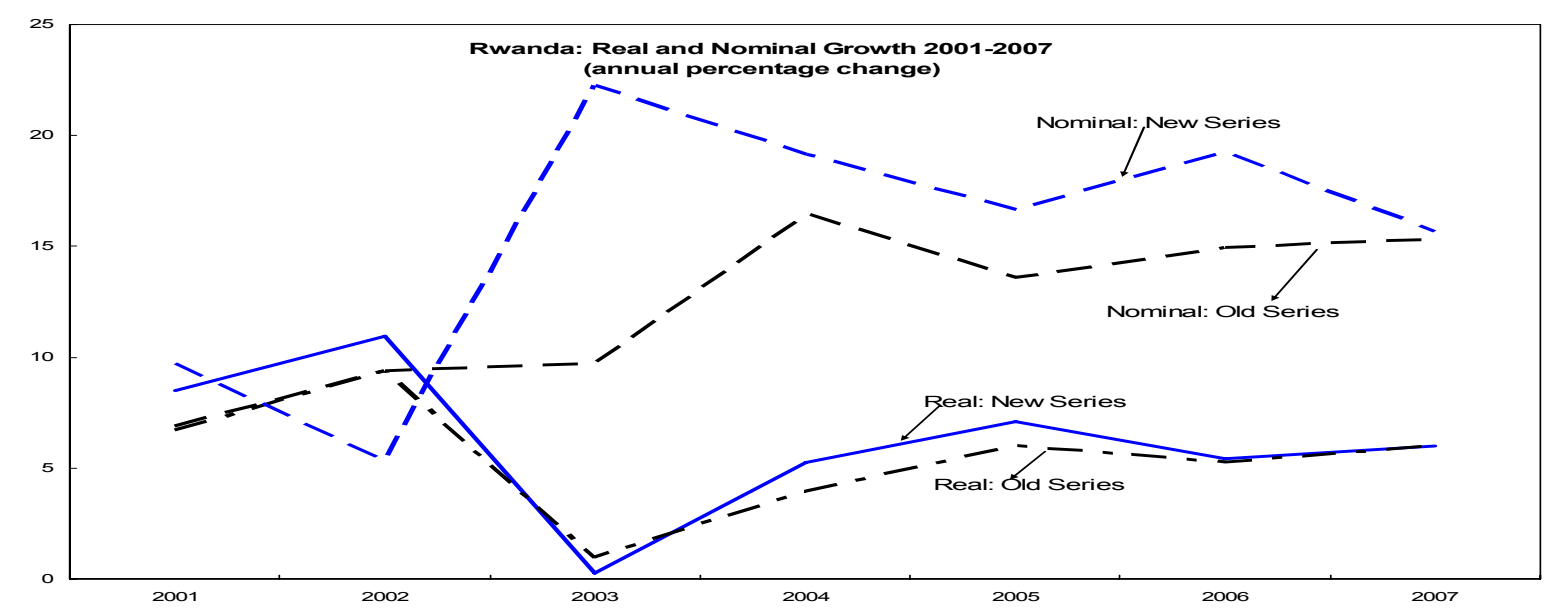

Sources: Rwandan authorities' and IMF staff estimates.

\section{The fiscal program remained broadly on track through end-September. ${ }^{1}$ Despite} higher outlays on some initially-underbudgeted social sectors, all fiscal targets for the first half of 2007 were met, reflecting buoyant revenues (owing to faster growth, higher inflation and improvements in tax collection) and expenditure restraint in non-priority areas. The cumulative overperformance of domestic revenue through end-September offset the acceleration of spending in the third quarter. However, the indicative targets on net credit to the government, domestic fiscal balance, and net accumulation of domestic arrears for endSeptember were missed due to delays in external disbursements from the AfDB and the Fast Track Education Initiative, which were received in the fourth quarter.

\footnotetext{
${ }^{1}$ Quarterly performance criteria and indicative targets for 2007 are presented in the MEFP, Table 1.
} 
Text Table 1. Rwanda: Operations of the Central Government, 2006-07

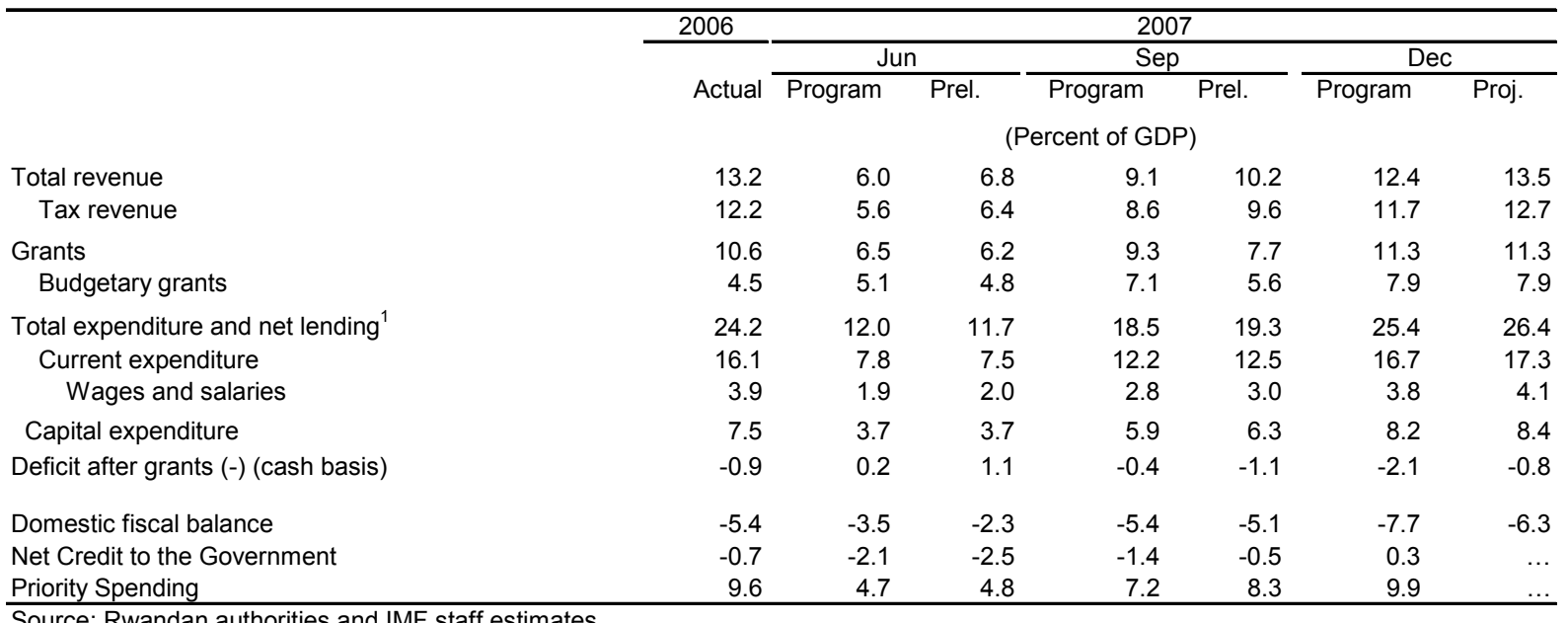

Source: Rwandan authorities and IMF staff estimates

${ }^{1}$ For 2007 , total expenditure and net lending excludes Rwandatel privatization receipts

3. The quarterly reserve money targets were met through end-September, but monetary management in the third quarter was difficult. A delay in the coffee harvest and the backloading of fiscal spending to the second half of the year injected extra liquidity into the economy during a short period. To achieve end-period reserve money targets, the National Bank of Rwanda (NBR) kept sales of foreign exchange in line with the program, and increasingly relied on sales of domestic assets for liquidity withdrawals. However, average reserve money and broad money exceeded program targets.

4. The Rwandan franc appreciated moderately against the U.S. dollar. In June, the NBR abolished the foreign exchange auctions, which had been hampered by a lack of effective competition, and began selling foreign exchange directly to banks at a daily fixed price (MEFP, ๆ5). Sales of foreign exchange increased during the second half of the year. 
Figure 2. Rwanda: Monetary Sector

The reserve money targets for the second and third quarters were met...

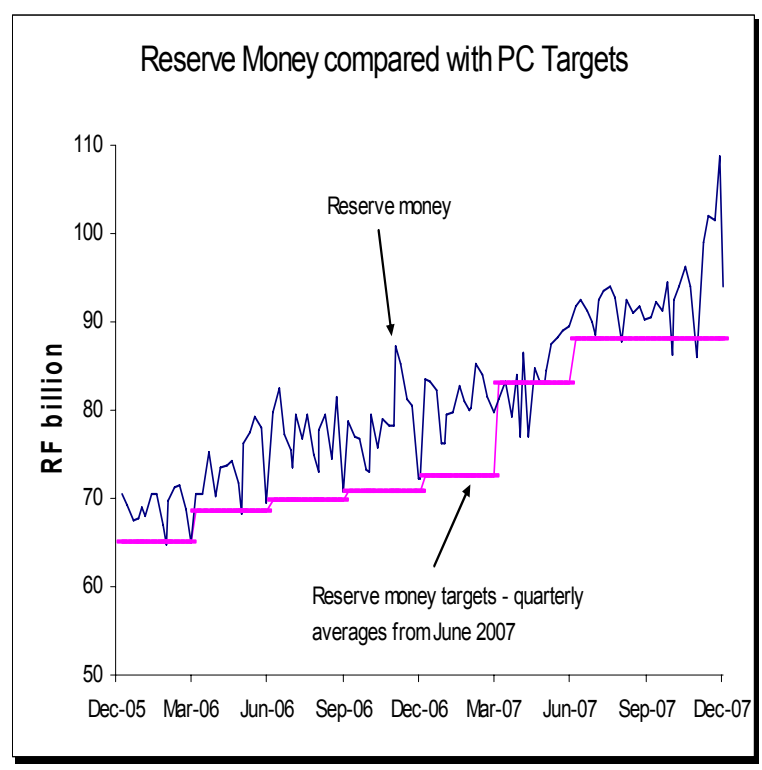

Foreign currency sales increased in the second half of the year.

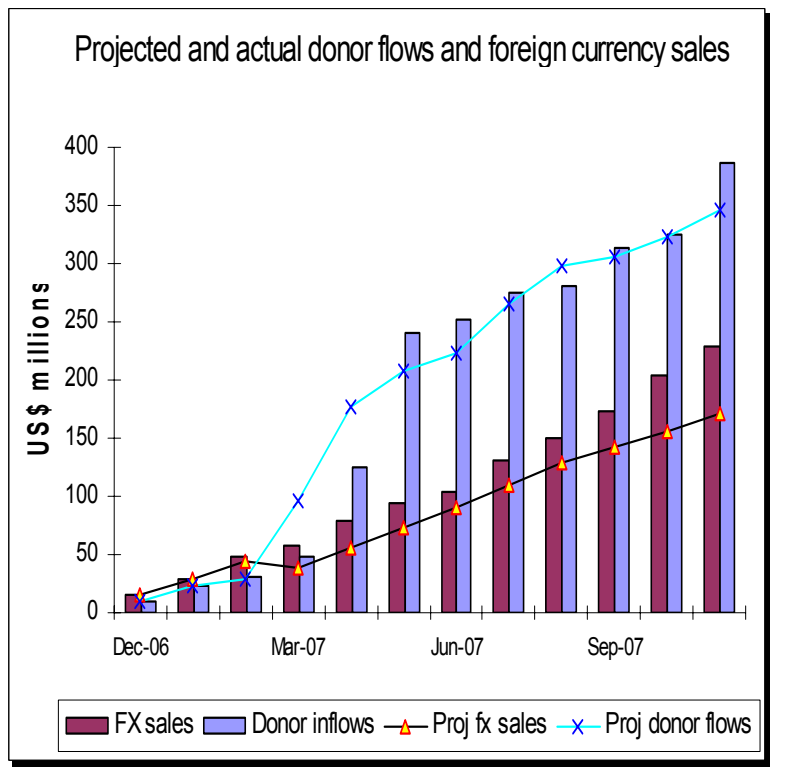

...but broad money was higher than anticipated.

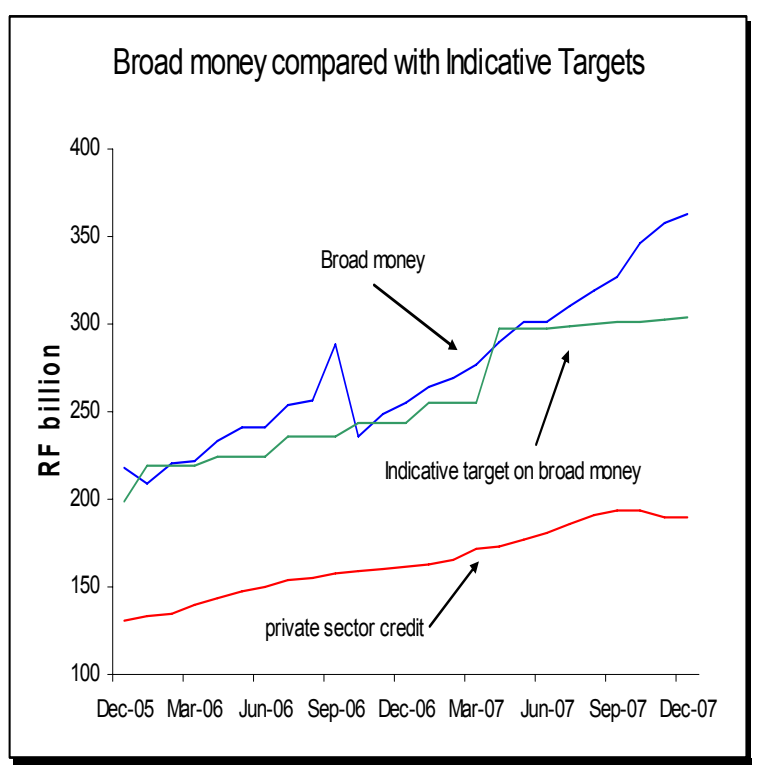

The Rwandan franc appreciated slightly.

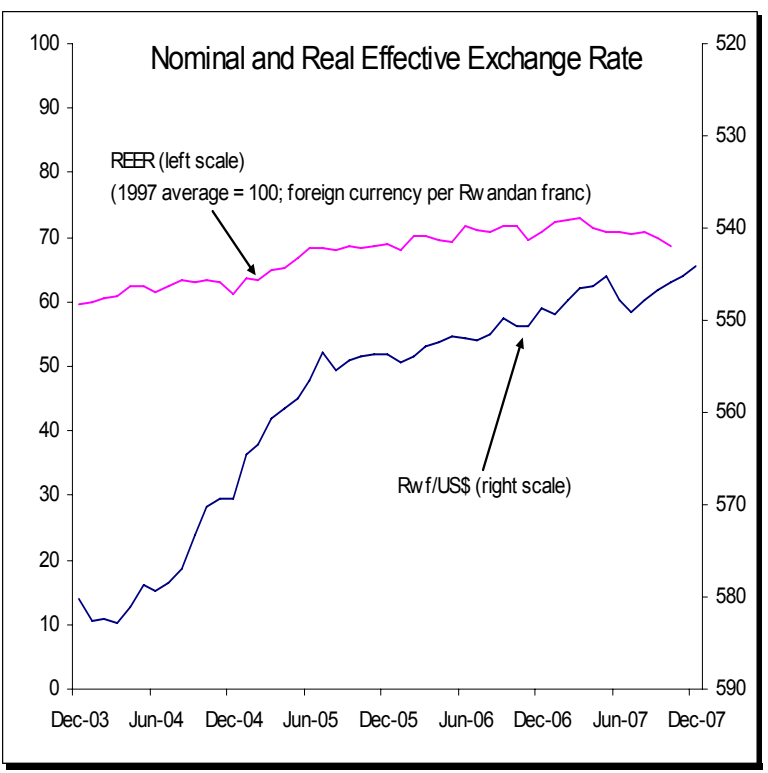

Sources: Rwandan authorities and IMF staff estimates and projections

5. The authorities have made progress on structural reforms, though some measures were finalized with a delay (MEFP Table 3). A progress report on financial reporting by budgetary agencies (June 15 benchmark) was published in September. The publication of the consolidated execution report of local governments for January to April, 
covering districts and provinces (July 31 performance criterion) was delayed until October, for which the authorities have requested a waiver (MEFP, ๆ7). Two structural benchmarks - a comprehensive review of the wage structure of the public sector, and the poverty profile of provinces, districts and communities - were not completed on time. The former was finalized in October, while the poverty profile was produced only for the province level, as expected external financing did not fully materialize.

6. Privatization proceeds exceeded expectations. RwandaTel was sold to Lap Green Networks, a Libyan firm, for a total of US\$100 million. In line with the program, the proceeds are to be saved through end-2007 and part of them will be used for future infrastructure investment (see below). The sale of Bank of Kigali has been delayed and is expected to take place during the first half of 2008.

\section{2008 Program-Making Headway On the Medium-Term Agenda}

\section{The medium-term policy agenda, formulated in the authorities' new PRSP} (Economic Development and Poverty Reduction Strategy_EDPRS), will focus on reducing poverty by preserving macroeconomic stability and removing impediments to growth (MEFP $9, \mathbf{8}){ }^{2}$ Consistent with these policy objectives, the 2008 macroeconomic framework allows for further scaling up of grants and fiscal spending. Real growth, currently projected between $5 \frac{1}{2}-6 \frac{1}{2}$ percent, could increase if a supply response to domestic spending were to materialize. ${ }^{3}$ Inflation is targeted to remain in single digits and international reserves at about $4 \frac{1}{2}$ months of imports. The current account is projected to widen: export increase will be more-than-offset by higher imports associated with the fiscal expansion and private sector investments in the tourism sector (MEFP, $1 \uparrow 6$ and 23).

\section{8 budget accommodates further scaling up of aid flows}

\section{The 2008 fiscal program allows for higher spending financed by further scaling} up of aid flows (Table 2). ${ }^{4}$ Spending increases, amounting to 2 percent of GDP compared to 2007, will focus on public infrastructure investment mainly in agriculture, education, health, electricity, and water. ${ }^{5}$ Should grants exceed program projections, the fourth PRGF review will assess whether additional contingent spending (of up to 0.5 percent of GDP) could be executed without jeopardizing macroeconomic objectives (MEFP, $\mid 14$ ), or should be saved. The revenue-to-GDP ratio is projected to increase by 0.2 percentage points of GDP to 13.7 percent of GDP - in line with the long-term objective of gradually widening the tax base. In the event of an unanticipated revenue shortfall, the authorities have committed to implement offsetting measures.

\footnotetext{
${ }^{2}$ The EDPRS was launched in late November 2007 and is presented to the Board together with the JSAN.

${ }^{3}$ The revised national accounts have been incorporated in the macroeconomic framework.

${ }^{4}$ The budget was approved by Parliament on December 17, 2007.

5 Spending measured as total expenditure and net lending excluding RwandaTel privatization proceeds.
} 
Figure 3. Rwanda: Fiscal Sector

A scaling up in foreign aid...

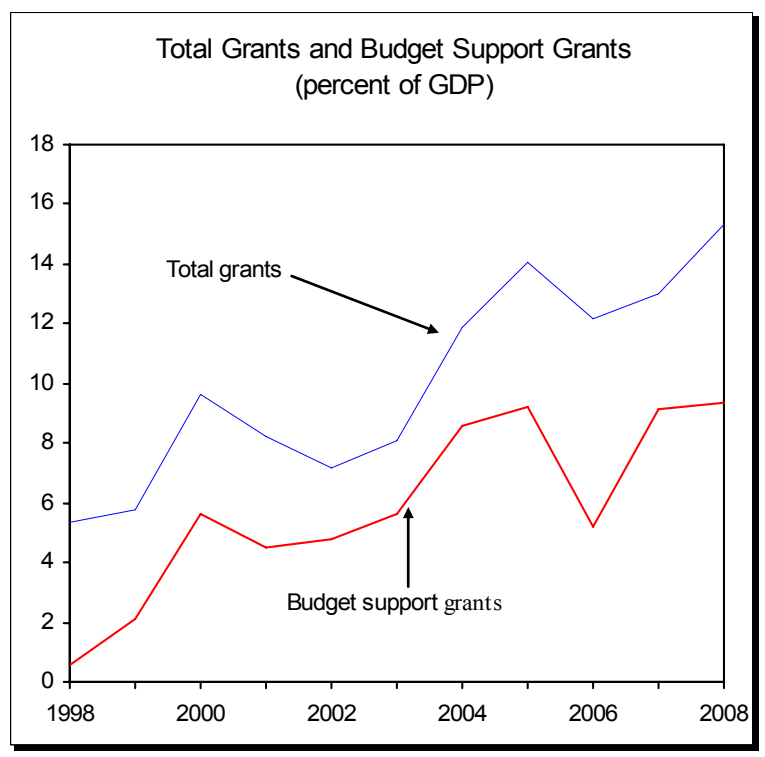

... has financed higher spending.

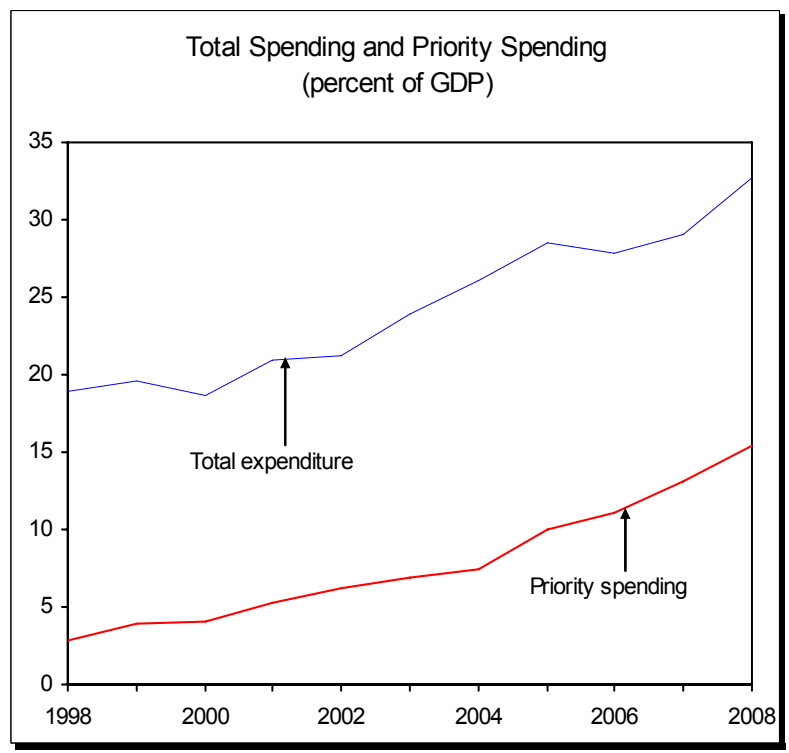

9. The staff emphasized the importance of vigilant monitoring of inflationary pressures in light of the unprecedented scaling up of spending. To prevent rekindling of inflation, the authorities are committed to adjust domestic spending to ease pressures on domestic demand (MEFP, $\mid 12)$.

\section{Infrastructure gap versus debt sustainability}

10. While Rwanda's development spending should be financed mostly through scaling up of aid, the authorities are considering borrowing on less concessional terms for a few projects that would alleviate binding infrastructure bottlenecks. The multiyear projects are in priority sectors identified in the PRSP, and are at different stages of preparation (MEFP, ๆ15). The authorities indicated that their attempts at accessing grants and highly concessional loan financing for infrastructure projects have not been successful.

- $\quad$ Energy. When compared with neighboring countries, Rwanda's energy is expensive and limited, thus hampering private sector activity (Text Table 2). Among other projects, the authorities are considering the construction of a hydro power plant at Nyaborongo (US\$120 million) to address their energy concerns. They have explored financing options and have received a loan commitment for US\$80 million from the Exim Bank of India on terms that are less concessional - 41 percent — than the 
50 percent required under the program. ${ }^{6}$ The authorities intend to request a modification of the program at the time of the fourth review once the full financing of the project has been identified, provided that an ongoing evaluation by the World Bank confirms the project's economic and financial viability, as described in the authorities' own assessment.

\begin{tabular}{|c|c|c|c|c|c|}
\hline \multicolumn{6}{|c|}{ Text Table 2. Rwanda: Electricity Usage and Cost } \\
\hline & Rwanda & Uganda & Tanzania & LDCs & Kenya \\
\hline $\begin{array}{l}\text { Electricity consumption } \\
\text { per capita (Kwh) }\end{array}$ & 14.0 & 51.7 & 54.4 & 112.4 & 124.9 \\
\hline $\begin{array}{l}\text { Electricity cost } \\
\text { (business use, US\$/Kwh) }\end{array}$ & 0.20 & 0.08 & 0.06 & $\ldots$ & 0.08 \\
\hline \multicolumn{6}{|c|}{$\begin{array}{l}\text { Source: World Development Indicators, United Nations, and World Fact Book. } \\
\text { Note: The data in the table reflect the latest information available between } \\
\text { 2002-2004. }\end{array}$} \\
\hline
\end{tabular}

- $\quad$ Agriculture. The authorities are preparing an investment project in agriculture aimed at easing pressures on arable land and improving agricultural productivity (Text Table 3). The staff encouraged the authorities to explore all possible sources of concessional financing as well as privatization receipts, and will continue discussions with the authorities at the time of the fourth review. The World Bank will assess the economic and financial feasibility of the project.

\footnotetext{
${ }^{6}$ The mission confirmed with individual donors (World Bank, the AfDB, and KFW) that lending by their commercial arms would not yield more concessional financing for such a large project.
} 


\begin{tabular}{|c|c|c|c|c|c|}
\hline \multicolumn{6}{|c|}{ Text Table 3. Rwanda: Agricultural land and productivity } \\
\hline & Rwanda & Uganda & Tanzania & Kenya & SSA \\
\hline Arable land (hectares per person) & 0.14 & 0.19 & 0.11 & 0.14 & $\ldots$ \\
\hline Arable land (\% of land area) & 48.6 & 26.4 & 4.5 & 8.2 & $\ldots$ \\
\hline Irrigated land (\% of cropland) & 0.12 & 0.12 & 3.6 & 2.0 & $\ldots$ \\
\hline Agricultural land (\% of land area) & 78.44 & $\cdots$ & 54.44 & $\ldots$ & $\ldots$ \\
\hline Cereal yield (kg per hectare) & $1,015.6$ & $1,694.6$ & $1,472.0$ & $1,322.3$ & $1,076.4$ \\
\hline \multicolumn{6}{|l|}{ Source: World Development Indicators. } \\
\hline \multicolumn{6}{|c|}{ Note: The data in the table reflect the latest information available between $2002-2004$. } \\
\hline
\end{tabular}

- Information and communication technologies (ICT). The fiscal program includes an investment of US\$15 million in the ICT sector in 2008, financed from RwandaTel privatization proceeds. The objective of the project (which complements other World Bank projects) is to provide a robust nationwide broadband network.

\section{The debt sustainability analysis (DSA) concludes that Rwanda remains at a high} risk of debt distress because of its small export base, with or without borrowing for the large infrastructure projects. ${ }^{7}$ Reflecting Rwanda's historically low export base, the NPV of external debt-to-exports ratio would breach the policy-dependent threshold of 150 percent by 2018 or five years earlier if the borrowing for the above-mentioned large infrastructure projects were included in the DSA. Even with such borrowing, however, external public debt service remains manageable, at below 10 percent of exports and 3-5 percent of revenue. Moreover, the authorities believe that there is an upside to the country's export potential if the projects are implemented, which would improve the related debt indicators.

\footnotetext{
${ }^{7}$ The full DSA analysis is elaborated in the accompanying Board document. The marginal growth impact of these projects is unknown and is assumed to be zero in the DSA.
} 
Figure 4. NPV of Debt-to-Export Ratio 2007-27

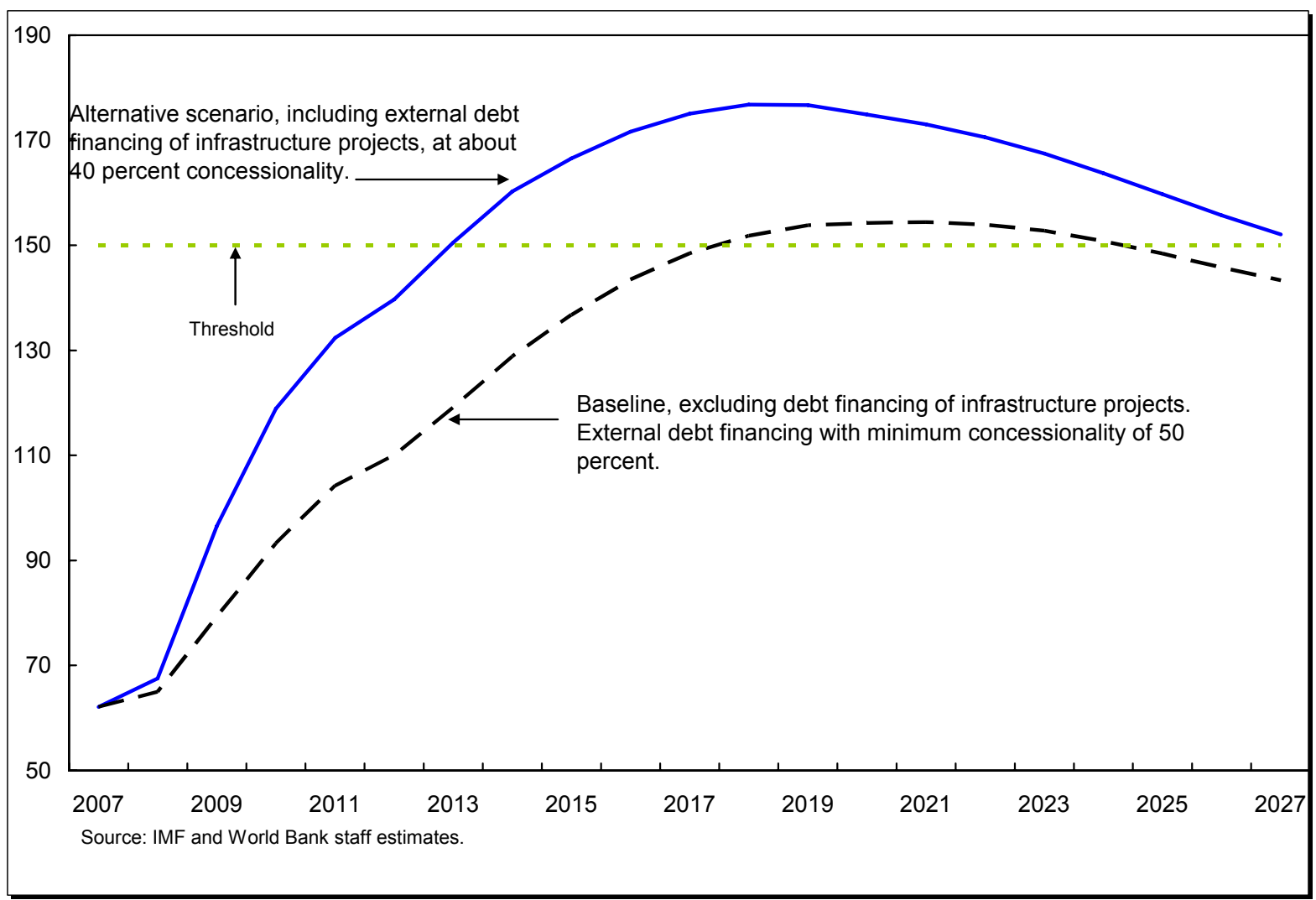

12. To prevent the reemergence of unsustainable debt, the authorities will prepare a debt management strategy that will guide future borrowing (MEFP, $\mid 17$ ). The staff stands ready to provide assistance as needed. Furthermore, the program for 2008 sets indicative limits on domestic debt and the net present value of external debt.

\section{Monetary and exchange rate policy}

13. The monetary program will aim to maintain single-digit inflation (MEFP, $₫ 18-22)$. The broad money target aims to minimize inflation risks and reduce the likely monetary overhang from the last quarter of 2007. At the same time, it will accommodate private sector credit growth of about 20 percent. Reserve money will remain the program anchor. To achieve the monetary targets, the staff emphasized the need for sufficient foreign exchange sales and flexibility in the exchange rate to ensure that sterilization with domestic assets does not lead to crowding out of the private sector and rapid accumulation of public debt. The staff also welcomed the authorities' plans to improve liquidity management and recommended lengthening the maturity profile of domestic debt. 


\section{Structural issues-maintaining reform momentum in macrocritical areas}

14. The authorities' structural agenda focuses on maintaining the momentum in the macrocritical areas. Accordingly, conditionality under the 2008 program - which has been streamlined relative to 2007 - covers the financial sector, tax administration and public financial management reforms (the rationale for each measure is provided in MEFP Table 4).

- $\quad$ Financial sector reforms are based on the authorities' Financial Sector Development Plan and include modernizing the national payments system, improving access to credit and financial services, upgrading accounting and auditing standards, and promoting contractual savings and nonbank financial institutions in order to mobilize long-term savings (MEFP, $\mid 28$ ).

- Tax administration reforms will aim to widen the tax base and raise the tax-to-GDP ratio over the medium term and improve trade facilitation. The revenue authority is developing a comprehensive compliance program designed to identify risks of noncompliance, in line with the recommendations made by the recent technical assistance mission on tax administration from the IMF's Fiscal Affairs Department (MEFP, \16).

- $\quad$ Public financial management (PFM). The government recognizes that further progress in enhancing fiscal discipline and budget credibility is a key priority, and is in the process of designing a new PFM medium-term action plan for 2008-2010 in cooperation with donors (MEFP, \17). Efforts in 2008 will support human and institutional capacity building, the implementation of an integrated financial management information system, the reinforcement of the medium-term expenditure framework, and the completion of a debt management strategy.

\section{Program Risks ANd Monitoring}

15. The aid-financed fiscal expansion increases program risks. If not managed properly, inflationary pressures could reemerge. In addition, a protracted crisis in Kenya could reduce economic growth and raise inflation, as most traded goods are transported through Kenya (Box 2).

16. Program monitoring for 2008 is described in the MEFP ( $\ 30$ and 31) and the technical memorandum of understanding. The program design remains the same, but adjusters were included for the performance criterion on reserve money and the indicative target on broad money to accommodate the transformation of the Union Banques Populaires du Rwanda (UBPR) into a commercial bank. The adjusters for minor aid shortfalls were also redesigned, to better insulate the budget against such shocks. 


\section{Box 2. The Implications of the Crisis in Kenya}

The Kenyan crisis is affecting Rwanda through disruptions in the supply of imported goods (fuel in particular), as Rwanda's main access to the sea is the port of Mombasa. In January, the authorities introduced fuel rationing to prevent hoarding, released fuel from the strategic fuel reserve to cover supply shortages, and signed an agreement with Tanzania to open up an alternative supply route. A prolonged crisis in Kenya may fuel inflation and reduce economic growth due to aggravated shortages of imported goods and/or higher transport costs for traded goods.

\section{StafF APPRAisAl}

17. Rwanda's performance has been encouraging. The continuation of rapid economic growth together with moderate inflation points to a positive supply response. The fiscal expansion was managed without rekindling excessive inflationary pressures but reserve money management has been difficult. The steady progress in structural areas reflects the authorities' ownership of the reform program.

\section{The staff believes that further fiscal expansion can be managed without} jeopardizing macroeconomic stability, but vigilance will be crucial. The NBR must carefully monitor inflationary developments and stand ready to step up foreign exchange sales, if necessary by allowing an appreciation of the exchange rate to avoid acceleration in inflation or crowding out of the private sector. If needed, the authorities should make adjustments to the planned release of the domestic component of spending. The staff also urges the authorities to improve liquidity forecasting and resist any new spending pressures.

\section{Rwanda remains at a high risk of debt distress; borrowing for large} infrastructure projects needs to be carefully considered, and in general, highly concessional borrowing continues to be appropriate. The infrastructure gap and the large financing needs pose a significant challenge. While investments are clearly needed, the projects should go forward only if assessed as economically viable. The staff encourages the authorities to use some of the privatization proceeds for financing of these projects, seek the most favorable borrowing terms for the remainder, and cooperate closely with development partners.

\section{PFM reforms must be stepped up, in order to improve the efficiency of fiscal} spending. The staff welcomes the authorities' intention to develop a new medium-term PFM action plan that would update the framework in which to carry out specific reform activities, 
guide the mobilization of resources, and improve coordination and sustainability of the reforms.

21. Prospects for financial sector reform are promising. The staff encourages the authorities to go ahead with the implementation of its Financial Sector Development Plan as agreements on the financing of the plan are reached.

22. The completion and publication of Rwanda's second PRSP is an important achievement. The staff congratulates the authorities for this document, which has been elaborated through a truly participatory process. The priorities identified during this process must now become the guiding tool for the elaboration of fiscal policy and provision of donor support to Rwanda.

23. The staff recommends that the requested waiver for a structural PC be granted - the nonobservance was temporary - and that the third review of the PRGF arrangement be completed. 
Table 1: Rwanda: Selected Economic and Financial Indicators, 2005-09

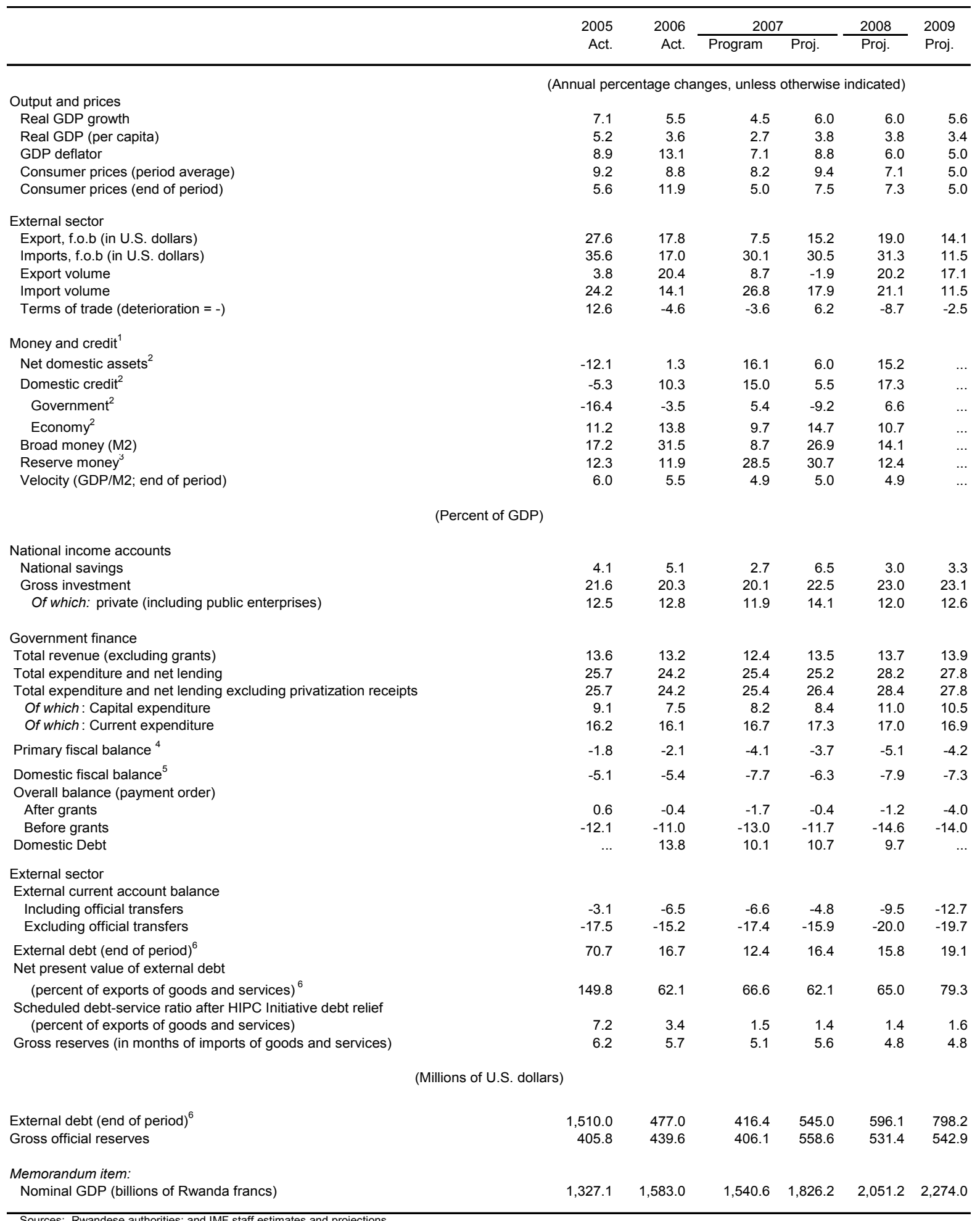

Sources: Rwandese authorities; and IMF staff estimates and projections.

${ }^{1}$ Data up to 2005 based on current exchange rates; for 2006, based on program exchange rate of RF 553.7/US\$, RF 549.9/US $\$$ for 2007, and RF 545/US $\$$ for 2008 .

${ }^{2}$ As a percent of the beginning-of-period stock of broad money

${ }^{3}$ Increase in 2007 reflects rebasing of the monetary program; reserve money growth will be limited to 13 percent after correcting for the rebasing at end-2006.

${ }^{4}$ Revenue excluding grants minus current expenditure except interest due and exceptional expenditure (AU peacekeeping expenditures and spending on demobilizing and intergrating militia groups) minus domestically financed capital expenditure.

${ }^{5}$ Revenue excluding grants minus current expenditure (excluding external interest) minus domestically financed capital expenditure and net lending. 


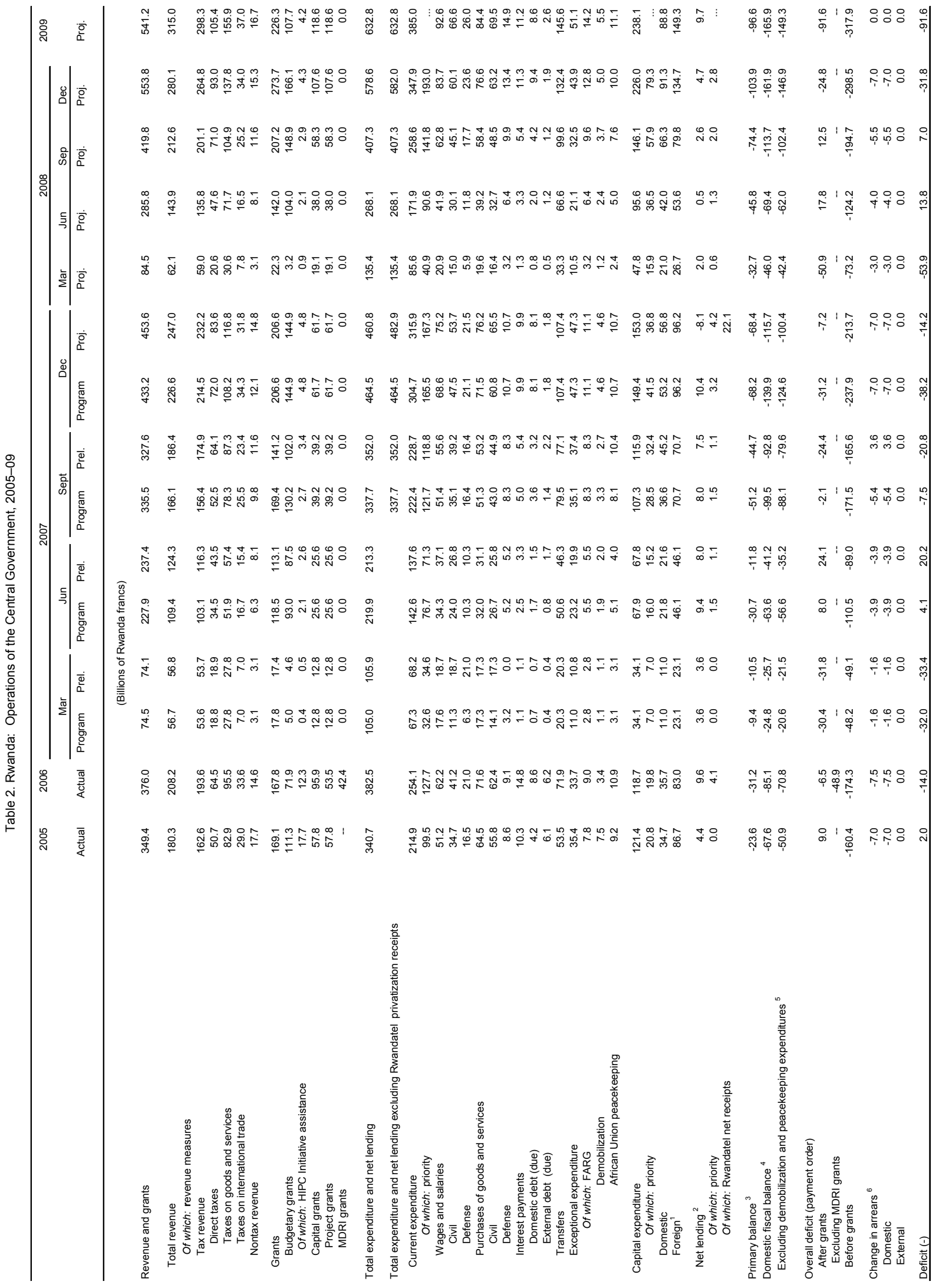




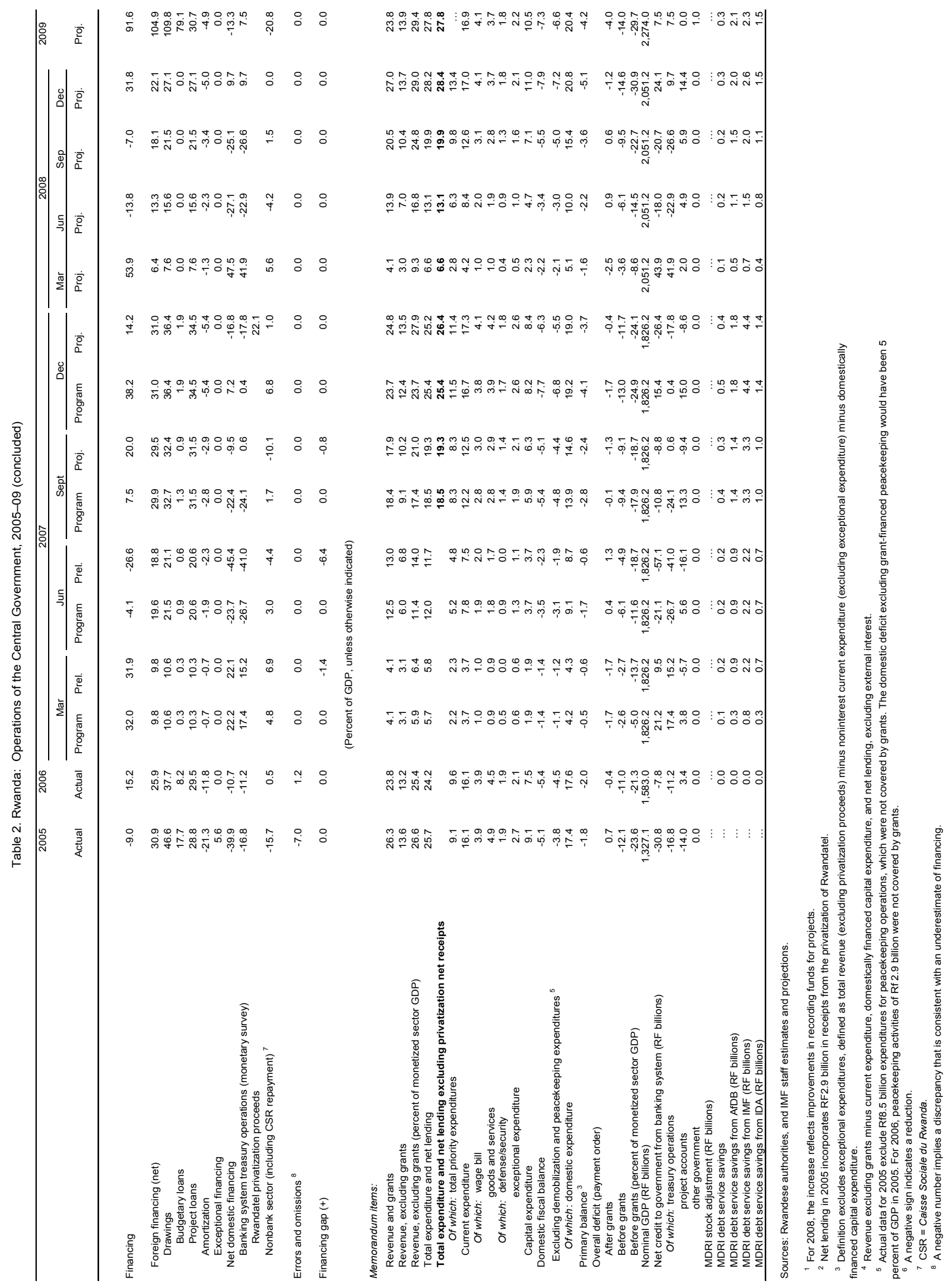




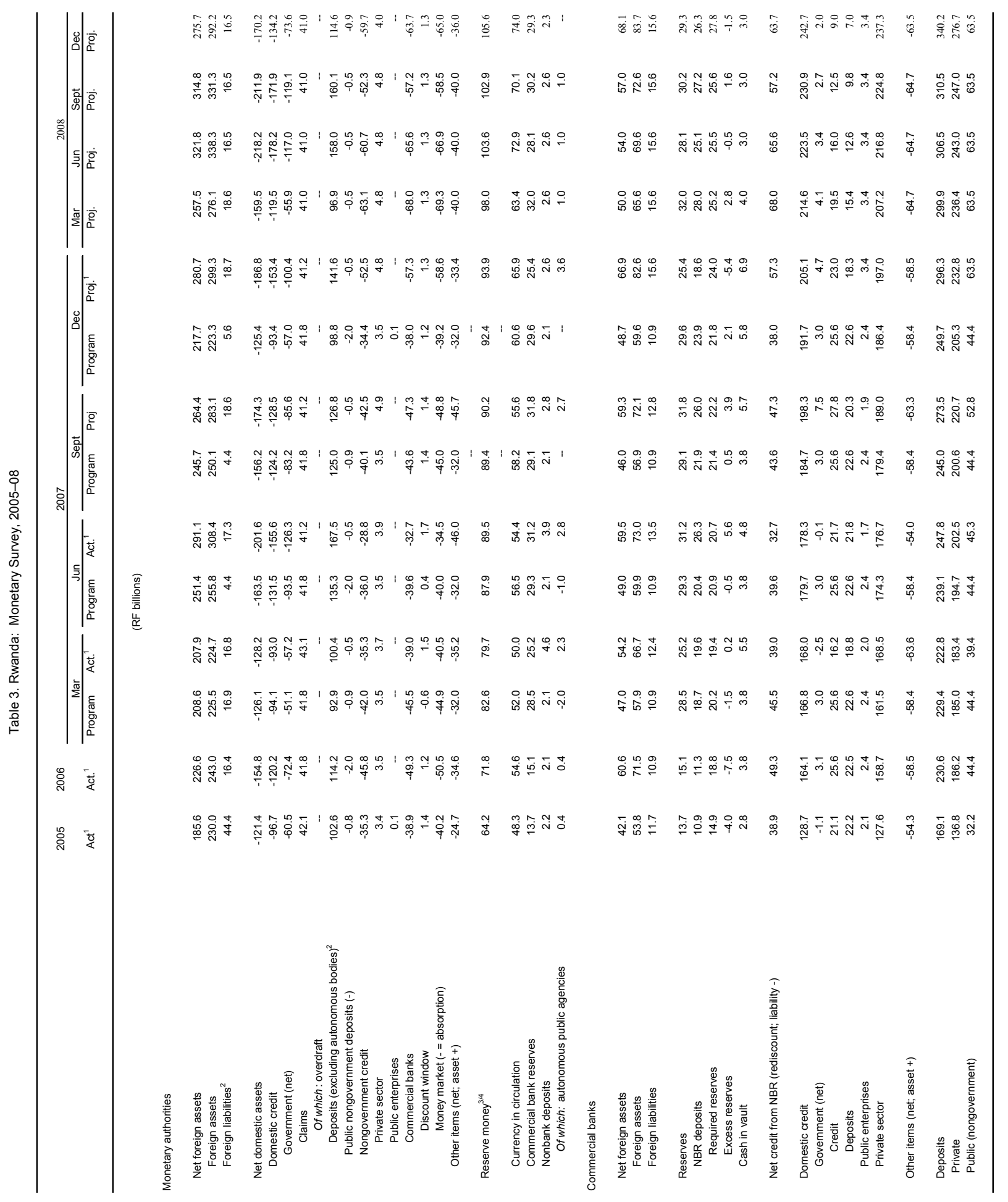




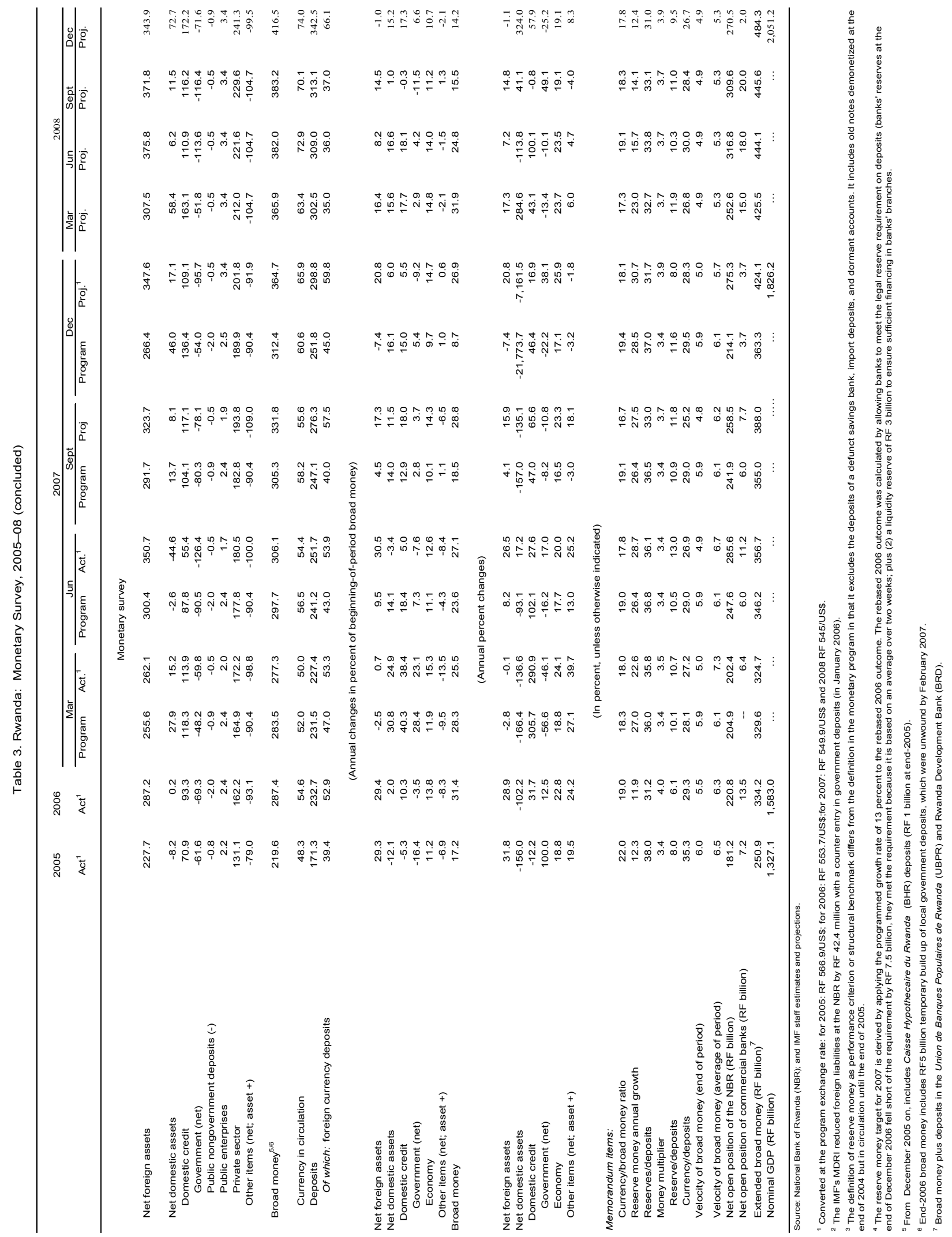




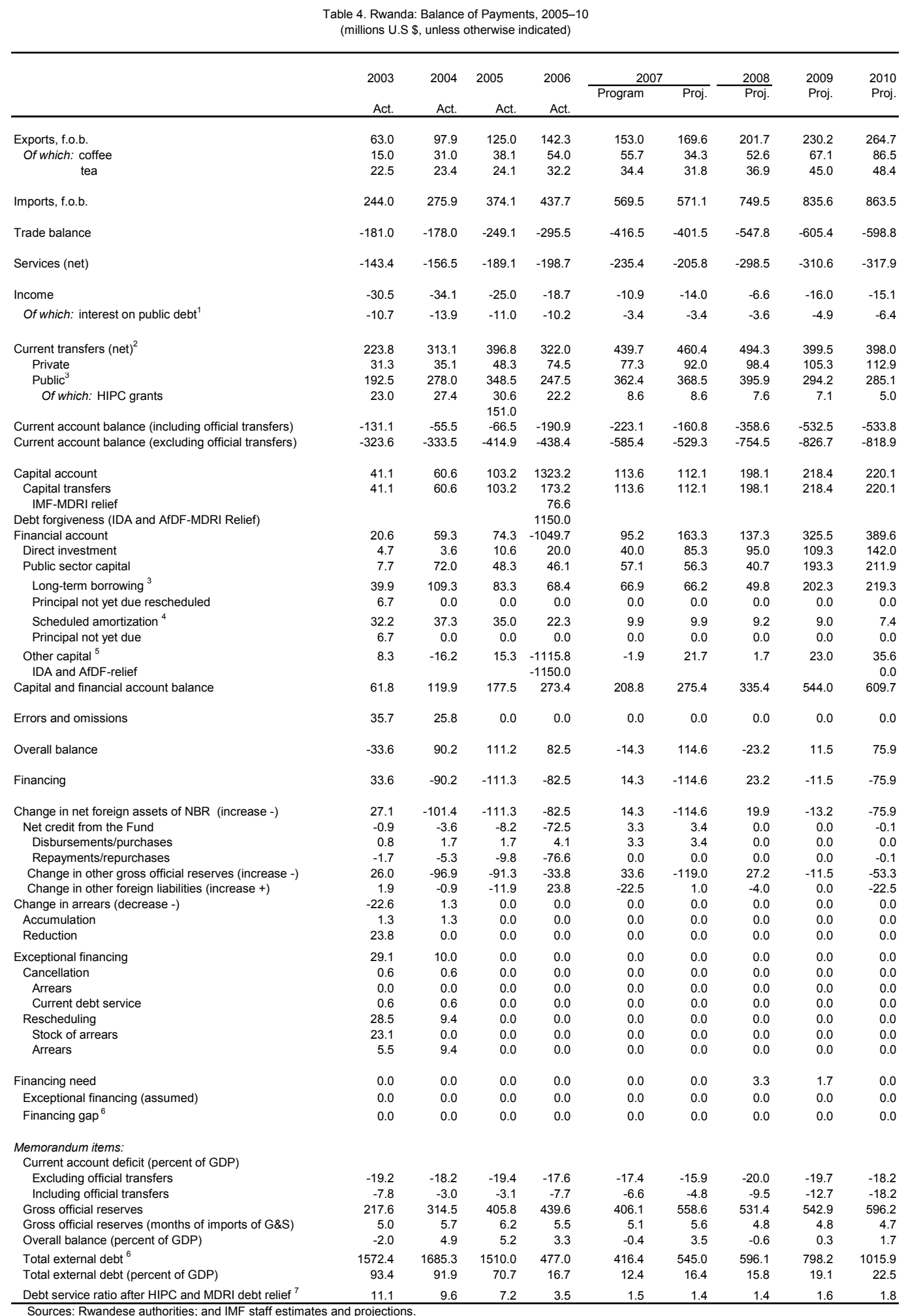

Sources: Rwandese authorities; and IMF staff estimates and projections.

${ }^{1}$ Including interest due to the Fund.

${ }^{2}$ Current transfers include disbursed budgetary and HIPC grants and humanitarian and technical assistance.

${ }^{3}$ Includes project loans and budgetary loans.

${ }^{4}$ Excluding Fund.

${ }^{5}$ Other capital includes long-term private capital, commercial credit, change in the net foreign assets of commercial banks, and unrecorded imports.

${ }^{6}$ After rescheduling, including arrears and new debt (the latter includes assumed project and budgetary disbursements for 2008).

${ }^{7}$ Reflects traditional debt relief from bilateral creditors and MDRI and enhanced HIPC Initiative assistance from both multilateral and bilateral creditors. Also includes additional bilateral debt relief delivered at the completion point. 
Table 5. Rwanda: Key Economic Variables as a Percentage of Revised and Old GDP

\begin{tabular}{|c|c|c|c|c|c|c|c|}
\hline & 2001 & 2002 & 2003 & 2004 & 2005 & 2006 & 2007 \\
\hline & \multicolumn{7}{|c|}{ Revised GDP } \\
\hline Nominal GDP (billions of Rwf) & 741.9 & 781.5 & 955.2 & $1,137.9$ & $1,327.1$ & $1,583.0$ & $1,826.2$ \\
\hline Per capita GDP (US\$) & 199.9 & 190.5 & 202.9 & 222.9 & 264.1 & 311.6 & 353.4 \\
\hline \multirow[t]{2}{*}{ Real GDP growth rate } & 8.5 & 11.0 & 0.3 & 5.3 & 7.1 & 5.5 & 6.0 \\
\hline & \multicolumn{7}{|c|}{ (Percent of GDP) } \\
\hline Revenue & 11.4 & 12.9 & 12.8 & 12.9 & 13.6 & 13.2 & 13.5 \\
\hline Total expenditure and net lending & 21.0 & 22.3 & 22.6 & 24.1 & 25.7 & 24.2 & 25.2 \\
\hline Capital expenditure & 6.6 & 5.2 & 5.4 & 7.9 & 9.1 & 7.5 & 8.4 \\
\hline Current expenditure & 14.2 & 15.7 & 16.8 & 14.8 & 16.2 & 16.1 & 17.3 \\
\hline Domestic fiscal balance & -2.3 & -4.0 & -4.5 & -4.8 & -3.8 & -4.5 & -5.5 \\
\hline \multicolumn{8}{|l|}{ External current account } \\
\hline Including transfers & -5.9 & -10.7 & 7.8 & -2.8 & -3.1 & -6.5 & -4.8 \\
\hline Excluding transfers & -15.9 & -17.8 & -18.2 & -16.8 & -17.5 & -15.2 & -15.9 \\
\hline \multirow[t]{2}{*}{ External debt } & 83.5 & 85.3 & 93.4 & 91.9 & 70.7 & 16.7 & 16.4 \\
\hline & \multicolumn{7}{|c|}{ Old GDP Series } \\
\hline Nominal GDP (billions of Rwf) & 754.3 & 825.0 & 905.3 & $1,054.3$ & $1,197.2$ & $1,375.7$ & $1,540.6$ \\
\hline Per capita GDP (US\$) & 203.2 & 201.1 & 192.3 & 206.6 & 238.3 & 270.8 & 302.8 \\
\hline \multirow[t]{2}{*}{ Real GDP growth rate } & 6.7 & 9.4 & 0.9 & 4.0 & 6.0 & 5.3 & 4.5 \\
\hline & \multicolumn{7}{|c|}{ (Percent of GDP) } \\
\hline Revenue & 11.4 & 12.2 & 13.4 & 13.6 & 14.6 & 14.1 & 15.6 \\
\hline Total expenditure and net lending & 21.0 & 21.2 & 24.7 & 21.9 & 27.0 & 28.1 & 30.9 \\
\hline Capital expenditure & 6.6 & 4.9 & 7.7 & 7.7 & 9.0 & 8.6 & 10.6 \\
\hline Current expenditure & 14.2 & 14.8 & 16.7 & 14.1 & 17.5 & 18.8 & 19.7 \\
\hline Domestic fiscal balance & -2.2 & -3.8 & -4.7 & -5.2 & -4.3 & -5.1 & -6.3 \\
\hline \multicolumn{8}{|l|}{ External current account } \\
\hline Including transfers & -5.9 & -10.1 & -11.3 & -12.3 & -9.0 & -10.8 & -8.1 \\
\hline Excluding transfers & -15.9 & -16.9 & -18.7 & -17.4 & -22.0 & -21.4 & -20.8 \\
\hline External debt & 83.5 & 85.3 & 86.1 & 82.2 & 73.7 & 15.0 & 14.6 \\
\hline
\end{tabular}


Table 6. Rwanda: National Accounts-Sector Composition, 2001-2007

\begin{tabular}{|c|c|c|c|c|c|c|c|}
\hline & 2001 & 2002 & 2003 & 2004 & 2005 & 2006 & 2007 proj. \\
\hline \multicolumn{8}{|c|}{ (RF Billions) } \\
\hline Nominal GDP & 741.9 & 781.5 & 955.2 & $1,137.9$ & $1,327.1$ & $1,583.0$ & $1,826.2$ \\
\hline Agriculture & 277.0 & 277.4 & 367.3 & 441.7 & 515.7 & 654.6 & 649.9 \\
\hline Manufacturing & 51.3 & 57.0 & 61.4 & 71.7 & 82.0 & 94.3 & 116.2 \\
\hline Construction and public works & 44.8 & 45.4 & 55.2 & 73.7 & 86.7 & 95.9 & 127.0 \\
\hline Services & 317.4 & 342.8 & 401.5 & 464.3 & 539.0 & 621.1 & 813.7 \\
\hline Commerce and tourism & 80.5 & 85.5 & 99.6 & 119.1 & 142.5 & 156.9 & 178.5 \\
\hline Transport and communications & 43.1 & 49.6 & 52.5 & 61.2 & 71.1 & 84.5 & 113.8 \\
\hline Public administration & 55.0 & 56.5 & 65.2 & 71.6 & 79.2 & 93.3 & 128.1 \\
\hline \multicolumn{8}{|c|}{ (In percent) } \\
\hline Real GDP growth rates & 8.5 & 11.0 & 0.3 & 5.3 & 7.1 & 5.5 & 6.0 \\
\hline Agriculture & 8.8 & 15.0 & -4.7 & 0.1 & 4.8 & 1.1 & -3.0 \\
\hline Manufacturing & 10.0 & 5.0 & -5.0 & -4.0 & 11.0 & 13.5 & 8.0 \\
\hline Construction and public works & 10.1 & 12.1 & 15.0 & 7.0 & 4.0 & 10.7 & 8.0 \\
\hline Services & 6.8 & 8.8 & 4.5 & 7.9 & 9.1 & 8.1 & 9.8 \\
\hline Commerce and tourism & 6.2 & 5.0 & 7.0 & 2.6 & 5.9 & 7.0 & 7.0 \\
\hline Transport and communications & 14.2 & 6.0 & -4.5 & 16.6 & 6.5 & 5.0 & 5.0 \\
\hline Public administration & 3.9 & 1.0 & 10.0 & 8.6 & 5.4 & 5.4 & 7.0 \\
\hline
\end{tabular}

Source: Rwandan authorities and IMF staff estimates 
Table 7. Rwanda: Proposed Schedule of Disbursements Under the PRGF Arrangement, 2008-09

\begin{tabular}{|c|c|c|c|}
\hline \multirow[t]{2}{*}{ Date } & \multirow[t]{2}{*}{ Conditions necessary for disbursement } & \multicolumn{2}{|c|}{ Amount } \\
\hline & & $\begin{array}{c}\text { (In millions of } \\
\text { SDRs) }\end{array}$ & $\begin{array}{l}\text { (In percent } \\
\text { of quota) }\end{array}$ \\
\hline February 29, 2008 & $\begin{array}{l}\text { Observance of performance criteria for June } \\
30,2007 \text {, and structural performance criteria } \\
\text { for July } 31 \text { and September } 30,2007 . \\
\text { Completion of the third review under the } \\
\text { arrangement. }\end{array}$ & 1.14 & 1.42 \\
\hline June 15, 2008 & $\begin{array}{l}\text { Observance of quantitative performance } \\
\text { criteria for December } 31,2007 \text {, completion of } \\
\text { the fourth review under the arrangement. }\end{array}$ & 1.14 & 1.42 \\
\hline October 15, 2008 & $\begin{array}{l}\text { Observance of quantitative and structural } \\
\text { performance criteria for June } 30,2008 \text {, } \\
\text { completion of the fifth review under the } \\
\text { arrangement. }\end{array}$ & 1.14 & 1.42 \\
\hline April 15, 2009 & $\begin{array}{l}\text { Observance of quantitative performance } \\
\text { criteria for December } 31,2008 \text {, completion of } \\
\text { the sixth review under the arrangement. }\end{array}$ & 1.17 & 1.46 \\
\hline & Total & 4.59 & 5.73 \\
\hline
\end{tabular}




\section{APPENDIX I-RWANDA: LETTER OF INTENT}

Kigali, February 12, 2008

Mr. Dominique Strauss-Kahn

Managing Director

International Monetary Fund

Washington, D.C. 20431

U.S.A.

Dear Mr. Strauss-Kahn:

1. The second review of our financial and economic program supported under the Fund's Poverty Reduction and Growth Facility (PRGF) was completed on June 25, 2007. In the attached Memorandum of Economic and Financial Policies (MEFP), we review recent economic developments and progress in the implementation of our program through the third quarter of 2007; and set out policies the Government intends to pursue in 2008.

2. Program implementation under the PRGF arrangement has been broadly on track. All quantitative and structural performance criteria for the completion of the third review were met with the exception of the performance criterion (PC) on the issuance of the first consolidated report of local governments showing transfers and budget execution per major line items per district and per province for the period January to April, 2007. The delay was due to misinterpretation of the PC by the Government of Rwanda. ${ }^{1}$ As the nonobservance was temporary, we are requesting a waiver for the nonobservance of the structural $\mathrm{PC}$ on the issuance of the consolidated report of local governments.

3. In support of our policies described in the MEFP, the Government of Rwanda requests the completion of the third review under the PRGF arrangement and the disbursement of the fourth loan of SDR 1.14 million.

4. The Government of Rwanda believes that the policies set forth in the attached MEFP are adequate to achieve the objectives of its program, but it will take any further measures that may become appropriate for this purpose. The Government of Rwanda will consult with

\footnotetext{
${ }^{1}$ Provinces are considered by the Government of Rwanda as part of the Central Government whereas the PC referred to them as Local Government. Consequently, while information on both provinces and districts was available, the latter alone was published by the target date.
} 
the Fund on the adoption of these measures and in advance of revisions to the policies contained in the MEFP, in accordance with the Fund's policies on such consultations.

5. The Government of Rwanda authorizes the publication and distribution of this letter, MEFP and TMU together with the related staff report.

\author{
Sincerely yours,$$
\text { / s / }
$$ \\ François Kanimba \\ Governor \\ National Bank of Rwanda

$$
\text { / s / }
$$ \\ James Musoni \\ Minister of Finance \\ Ministry of Finance and Economic Planning
}

Attachments: Memorandum of Economic and Financial Policies

Technical Memorandum of Understanding 


\section{APPENDIX I-ATTACHMENT I \\ Memorandum of Economic And Financial Policies (MEFP) of the Government of Rwanda}

February 12, 2008

1. Rwanda's medium-term economic program is supported by an arrangement under the Poverty Reduction and Growth Facility over 2006-2009. We are committed to reducing poverty through preserving macroeconomic stability, boosting economic growth, and implementing policies targeted at improving the livelihood of the poor. This memorandum is consistent with the goals established in the new Economic Development and Poverty Reduction Strategy (EDPRS), which was launched in November 2007. The memorandum reviews the recent performance under the program through the third quarter of 2007 and describes the policies for 2008 .

\section{RECENT ECONOMIC DEVELOPMENTS}

2. Growth remains strong and inflation has abated. GDP growth is expected to reach about 6 percent in 2007, owing to buoyant activity in the construction and services sectors, despite a fall in agricultural production. The stabilization in food prices has reduced inflation, which declined to 8 percent in October from a peak of 12 percent at end-2006.

\section{The fiscal program has remained broadly on track through September 2007.}

- $\quad$ Fiscal policy in the first half of 2007 was tighter than programmed because of higher revenues and spending shortfalls. Revenues overperformed reflecting mostly an increase in collections from income and consumption taxes. With the exception of wages and salaries, spending on all programs was restrained because of delays in finalizing contract documents and procurement processes. Nevertheless, the target on priority spending was achieved. The tighter fiscal stance allowed domestic debt to remain within targeted levels.

- $\quad$ Spending accelerated in the third quarter of the year and the revenue overperformance continued. Spending through September was higher than programmed reflecting additional outlays for wages of health and education workers, purchase of seed and fertilizer, and maintenance of the road network. As a result, the target on priority spending was met by a wide margin. However, the end-September indicative targets on domestic fiscal balance, net credit to the government and net accumulation of domestic arrears were missed because of delays in disbursements from the AfDB and the Fast Track Education Initiative. These disbursements were received in the fourth quarter.

- $\quad$ Domestic petroleum prices were adjusted periodically in response to world oil market developments. We remain committed to generating positive revenues from petroleum taxes. 
4. The reserve money targets for end-June and end-September 2007 were met. However, monetary management during the third quarter of 2007 was rendered difficult because of the delayed coffee harvest and the back loading of fiscal spending to the second half of the year. The National Bank of Rwanda (NBR) kept sales of foreign exchange in line with program targets and resorted to sterilization using domestic instruments to keep reserve money within the program limits. Broad money accelerated beyond the target.

5. The Rwandan franc moderately appreciated against the U.S. dollar. The central bank abolished the foreign exchange (forex) auctions in June and began selling foreign exchange directly to banks at a predetermined reference price (based on price data from the forex interbank market, foreign exchange retail prices, and the previous day's reference price). This triggered an unintended depreciation in July and the central bank subsequently added an adjustment to the pricing formula in August, aiming to gradually appreciate the franc. The move to on-tap sale has enabled NBR to sell more foreign exchange in the second half of the year.

\section{The external current account is expected to improve relative to the program in}

2007. During January-September, exports grew at a faster rate than anticipated, and the overall increase in receipts of mineral exports is projected to more than offset the decline in volumes of coffee exports for the whole year. Imports are projected to remain in line with the program; strong growth was recorded during January-September, particularly in the importation of capital and consumer goods.

\section{Progress was made on the structural front.}

- $\quad$ Our efforts in public financial management reforms are beginning to show results, and we will continue to accelerate the pace of reforms as we address capacity constraints. The progress report on financial reporting by budgetary agencies (June 15 benchmark) was published in September. Part of the consolidated execution report of local governments showing transfers and budget execution for districts over the period January to April 2007, was published in July (July 31 performance criterion). The remaining part of the report covering provinces was published in October after the Government of Rwanda received clarification on the PC requirements from the IMF staff. The study on project accounts (end-September performance criterion) and the progress report on the implementation of the Organic Budget Law (end-September benchmark) were published on time in September. The 2008 Financial Bill (annual budget) was prepared in line with the new chart of accounts and revised sector and economic classifications.

- $\quad$ To develop and strengthen the nonbank financial sector, the microfinance bill providing the legal and regulatory framework for microfinance institutions was submitted to the Parliament in June (end-June benchmark). An insurance bill was submitted to the Cabinet and we have established a unit in the NBR to supervise nonbank financial institutions. The targeted microfinancial institutions and most banks have complied with the new capital requirements, which are geared at increasing the safety of the financial system, ahead of the January 2008 implementation date. The amendments to the Banking Law were approved by the Parliament in October and we are preparing the related regulations. The lower chamber of Parliament approved the 
Anti Money Laundering/Combating the Financing of Terrorism Bill and submitted it to the upper chamber for review.

- The restructuring and reorganization process for the transformation of the Union Banques Populaires du Rwanda (UBPR) - a large microfinance network —into a commercial bank has commenced. We anticipate that the process will be completed in the first quarter of 2008. With the conversion of UBPR into a commercial bank, it will be included in the program definition of reserve money. We are therefore including an adjuster on reserve money in the TMU.

- $\quad$ RwandaTel was sold to Lap Green Networks, a Libyan firm, for a total of US\$100 million (\$50 million down payment was received in November). In line with the program, the proceeds are saved through end-2007 and will be used in the future for investment in information and communications technology, and other priority sectors.

- A number of measures to reduce the cost of doing business were introduced, including through the implementation of the Commercial Justice, Business, and Land Registration Program. The investment climate project, which will assist in implementing the Rwanda Commercial Registration Services Agency, was established in July 2007. Eight business development centers were set up at the district level. The legislation establishing specialized procedures for the commercial courts was approved by the Parliament. This will enable fair and speedy resolution of commercial disputes. A draft Ministerial Decree on land use that provides for procedures regarding land application, allocation and registration will be submitted to Cabinet. The number of procedures required from land application to issuance of a building permit was reduced from 17 to 7 . Additionally, we have reduced the number of documents required for exports from 14 to 9 and imports from 19 to 9 in 2007.

- Two structural benchmarks - a comprehensive review of the wage structure of the public sector, and the poverty profile of provinces, districts and communities-were not completed on time. A draft of the former was prepared by October and finalized by year-end. The poverty profile was only produced for the province level because expected external financing to support the other levels did not fully materialize.

\section{MEDIUM-TERM STRATEGY}

8. Our medium-term policy agenda will focus on reducing poverty by improving food security and creating social protection schemes, removing impediments to growth, and preserving macroeconomic stability. The policies are based on the Vision 2020 development plan and are further formulated in the new EDPRS. The main elements include:

- $\quad$ Enhancing agricultural development and trade as vehicles to empower the poor by having them participate in economic activity. 
- $\quad$ Removing obstacles to private sector development to make it the engine of growth. To this end, we will continue building human capital through better health and education, and address skill shortages.

- $\quad$ Addressing severe infrastructure bottlenecks, including the insufficient and expensive energy supply, poor road network, our shallow financial system, and the high costs of doing business.

- $\quad$ Improving the delivery of public services through better expenditure management, and better analyses and monitoring of the links between policies, growth and poverty reduction. Through better monitoring we will identify worthy programs and projects that can be scaled up.

- $\quad$ Relying on sustainable financing sources with an emphasis on grant financing and raising the revenue ratio in the long run.

- Developing on a pilot basis the grassroots "Umurenge" scheme. For small villages, Umurenge will consolidate existing social protection schemes toward income generation for food security and build savings for village investments.

While our medium-term macroeconomic framework is based on prudent projections for growth and external assistance, we believe that steadfast implementation of our reform agenda is likely to lead to substantially higher-than-projected growth and we hope that it could facilitate higher levels of external assistance. Moreover, to further improve the policy dialogue with stakeholders and development partners, we will maintain a rolling mediumterm expenditure and macroeconomic framework. 


\section{Box 1. Alleviating Poverty over the Medium Term}

Recent socioeconomic surveys have found that high growth rates have not substantially reduced poverty and that poverty varies noticeably by location.

To address this shortcoming, the EDPRS promotes three main pillars which will serve to (a) prioritize actions, (b) mobilize resources for development, and (c) improve policy implementation through more co-ordinated interventions across sectors:

- $\quad$ Sustainable growth for employment and exports; reducing the operational costs of business (including through infrastructure investment), increasing the skills of the labor force, and developing the financial sector.

- $\quad$ Pro-poor components of the national growth agenda; improving the productive capacity of the poor in rural areas through a combination of public investment and works, credit packages and direct support.

- $\quad$ Governance; empowering citizens through legal and public sector reforms, which will enhance human rights and transparency and accountability in fiscal and regulatory matters.

We are developing a Common Performance Assessment Framework (CPAF) in cooperation with donors to monitor the implementation of the poverty reduction strategy. There will be two types of indicators:

(a) indirect process/action indicators, monitoring the progress of reform implementation, and

(b) output/performance indicators that are directly linked to the final output. Donors are expected to begin using a subset of these indicators as triggers for their disbursements in 2009.

III. The Program for 2008

9. Our policies in $\mathbf{2 0 0 8}$ will focus on poverty reduction initiatives, lay the base for stronger medium-term growth and continue to safeguard macroeconomic stability. We expect real growth of $5.5-6.5$ percent, and possibly 7 percent. ${ }^{1}$ We intend to maintain inflation within single digits, and a level of international reserves of about $4 \frac{1}{2}$ months of imports. Macroeconomic and structural policies will focus on improving public financial management, developing the financial sector, and growth-enhancing investments and reforms.

\section{The macroeconomic framework for the 2008 program was designed before the} recent political crisis in Kenya. The recent crisis, if prolonged, could have adverse macroeconomic implications for the region, including Rwanda. We will assess the economic implications at the time of the fourth review.

\footnotetext{
${ }^{1}$ The macroeconomic program is rebased using the new national accounts data prepared by the National Institute of Statistics (NIS). The national accounts have been rebased from 1995 to 2001 and reflect information from the 2005 household survey and an improved statistical methodology that is consistent with international standards.
} 


\section{A. Macroeconomic Program}

11. Managing the domestic demand impact of fiscal policies will lie at the heart of our macroeconomic policies. Financed by higher aid flows, the domestic deficit (excluding spending on demobilization and peacekeeping) is projected to increase by about 1.7 percent of GDP compared with 2007. Thus, pressures for a real exchange rate appreciation are expected to continue and could be exacerbated by off budget project spending. If grants exceed program projections, we will release the so-called contingent spending (see paragraph 14) only after a careful assessment of macroeconomic conditions in the context of the fourth review under the PRGF.

\section{Fiscal Policy}

12. The objective of our fiscal program is to further improve the living standards of our population and boost productivity. The 2008 budget allows for an increase in investment spending financed by a scaling up of aid flows. Prudent management of aid must be consistent with the single-digit inflation objective, and must focus on preventing a crowding out of the private sector and building up costly domestic debt. Should the domestic debt target be exceeded, this would signal that the spending increase was too rapid, forcing the NBR to resort to sterilization of the liquidity impact from the additional spending through domestic asset sales. In this case, the Ministry of Finance would adopt a more gradual approach in releasing the domestic component of the budget in the following month. The fiscal program will be reviewed at the time of the fourth review under the PRGF, in light of developments in key macroeconomic indicators in 2007.

\section{On the revenue front, we will increase the revenue-to-GDP ratio by} 0.2 percentage points to 13.7 percent of GDP. Should unanticipated revenue losses arise, we will implement offsetting measures - including increasing fees and charges - so that the 2008 revenue target can be attained. Our measures aimed at widening the tax base are described in paragraph 16 . To support the revenue target, no further tax exemptions will be granted and the existing ones will be carefully managed.

14. Spending will increase by about 2 percent of GDP, with a larger share targeted at priority spending. ${ }^{2}$ We will dedicate more resources to public infrastructure-to strengthen private sector led growth, especially in the rural areas-and to agriculture, education, health, electricity, and water. We have ensured that expenditures are not underbudgeted in the 2008 budget, and we will execute the fiscal spending in line with the budget. Should additional grants materialize, we will assess, in the context of the fourth PRGF review, whether it is possible to release contingent spending of about 0.5 percent of GDP for priorities and nonpriorities. Below we outline the main issues regarding key spending areas:

\footnotetext{
${ }^{2}$ Spending measured as total expenditure and net lending excluding Rwandatel privatization proceeds.
} 
- $\quad$ Food security. Given uncertainties related to weather conditions, the program continues to include an adjuster allowing an increase in the deficit and a commensurate reduction in net foreign assets for food imports related to a food emergency.

- $\quad$ Priority spending. Priority spending, excluding the contingency, will increase by about 2 percent of GDP. Priority spending will focus in particular on agriculture, health, education, export promotion, infrastructure and energy.

- $\quad$ Spending in education will increase by about 0.6 percent of GDP. Most of this will go toward improving delivery of primary education through the capitation grant and purchase of education materials. Special emphasis is also placed on training and skills development; allocations have been made to establish three vocational training centers.

- $\quad$ To address the issue of limited and insufficient energy, we are in the process of constructing eight micro hydro dams, have begun the construction of the Rukarara hydro dam and are considering another at Nyaborongo. We are also rehabilitating the infrastructure to improve efficiency in the transmission and distribution of electricity, and are expanding the electricity grid system. Due to unforeseen circumstances, the heavy fuel generator will become operational during the first quarter of 2009 and not at end-2007 as envisaged earlier. Consequently, we will continue to subsidize Electrogaz ( 0.5 percent of GDP) for costs related to the rental of generators and fuel costs.

- With the help of donors, we are focusing on providing adequate health services. To avoid a repeat of the underbudgeting that occurred in 2007, the budget accommodates an increase of 0.6 percent of GDP in health spending. This will finance programs to improve primary health care by hiring qualified staff, financing of the 'mutuelle scheme' and purchase of drugs. In the first quarter of 2008 we will undertake a comprehensive review of the health sector to identify priorities and to better understand the financing requirements of the sector.

- $\quad$ The budget includes an allocation of about 0.3 percent of GDP to finance parliamentary elections in 2008. 
Text table 2. Priority spending

(In percent of GDP)

\begin{tabular}{lcc}
\hline & $\begin{array}{c}\text { 2007 } \\
\text { w/o cont. }\end{array}$ & w/o cont. \\
\hline Priority & $\mathbf{1 1 . 4}$ & $\mathbf{1 3 . 4}$ \\
Of which: & & \\
Agriculture, land, and water & 1.3 & 1.3 \\
Health & 1.4 & 2.0 \\
Education & 4.1 & 4.6 \\
Infrastructure and energy & 2.0 & 2.4 \\
Export and investment promotion & 0.3 & 0.3 \\
Internal security & 0.5 & 0.7 \\
Decentralization & 1.0 & 0.8 \\
Other & 0.9 & 1.2 \\
\hline
\end{tabular}

Sources: Rwandese authorities and IMF staff

\section{Other Spending}

- $\quad A U$ peace keeping in Darfur. We will continue to monitor the costs associated with our peace keeping activities. The Auditor General will publish by end-May 2008 an audit of the spending in 2007.

- $\quad$ Military spending will remain at about 2 percent of GDP.

15. We are placing special emphasis on infrastructure investment that should help alleviate bottlenecks to private sector growth. We are focusing on the priority sectors outlined in the EDPRS. We will explore different sources of financing, including donor support, our own privatization receipts, and external borrowing. We will develop these plans in the context of sector development strategies in close consultation with our development partners. To avoid reaccumulating unsustainable levels of debt, we will prepare and implement a debt management strategy (see paragraph 17).

- Energy. We are considering the Nyaborongo hydro dam, which would increase our current electricity production by over 50 percent from the current level of $50 \mathrm{MWh}$. The construction and transportation cost of this 4-year project is expected to be $\$ 106$ million. ${ }^{3}$ The World Bank is conducting an assessment of the economic and financial viability of the project. The project could begin in 2008 , once total financing has been identified, provided that the viability assessment is favorable. We will institute measures to ensure that construction conforms with our laws governing social and environmental impact issues. We have identified US\$80 million in financing from

\footnotetext{
${ }^{3}$ There is an additional US\$14 million in costs associated with project supervision and environmental protection.
} 
the Exim Bank of India on terms that are less concessional (41 percent) than the 50 percent required under the program. We have explored various financing options, but have been unable to secure more concessional financing. If we decide to proceed with the project, taking into account its importance for reducing energy shortagesone of the main bottlenecks to private sector growth - we intend to request a modification of the program to accommodate this borrowing at the time of the fourth review.

- Information and communication technologies (ICT). We envisage investing a portion of the proceeds from privatization of RwandaTel in the ICT sector. The objective of the project is to provide a robust nationwide broadband backbone using fiber optics to (i) strengthen the delivery of social services in rural areas, especially in health and education, (ii) improve efficiency in the way local government operates, including through strengthening information sharing and coordination between local and central governments, particularly in public financial management and M\&E; and (iii) provide infrastructure for the Electrogaz modern network management system. Over time it is expected that the availability of this ICT backbone will also provide a platform to induce new economic activity, especially in previously underserviced rural areas. The 2008 budget includes US $\$ 15$ million for extension of the network of fiber optic cables to districts. The project will be completed in 2009 .

- $\quad$ Agriculture. We are in the process of preparing a 3-year investment project in agriculture that focuses on land-husbandry, water harvesting and hillside-irrigation. The World Bank will assess the economic and financial feasibility of the project, and we will consider proceeding with the project only if this assessment is favorable. The preliminary cost estimate of the project is US\$100 million. We will explore all possible sources of financing, including grants and concessional borrowing from our development partners. To mitigate the future debt burden, we also intend to use some of the receipts from the privatization of RwandaTel for the partial financing of this project.

\section{Fiscal structural reforms}

16. We plan to improve the efficiency of tax administration to widen the tax base and raise the tax-to-GDP ratio over the medium term. The measures that we will introduce are in line with the recommendations made by the technical assistance mission on tax administration from the IMF's Fiscal Affairs Department, and the study by Deloitte \& Touche. These efforts will focus on two broad areas:

- $\quad$ Widening the domestic tax base. The revenue authority is developing a comprehensive compliance program designed to identify risks of noncompliance. Execution of the program includes enhancing the SIGTAS computer system to strengthen information analysis and, undertaking risk based audits. We will develop by June 30, 2008, a comprehensive program for the medium-sized taxpayers (benchmark), expanding the segment to include all taxpayers above the RF20 million VAT threshold. This is expected to increase the number of taxpayers in this segment from 200 to 900 . We will 
also improve service delivery to our taxpayers, for example, by refunding VAT claims promptly and enforcing tax regulations consistently.

- $\quad$ Facilitating trade. Our objective is to provide an efficient service to the private sector. As an important step, we will implement by June 30, 2008 an expedited clearance scheme (super green/gold card) for compliant importers contributing between 40 and 60 percent of import value (benchmark).

17. The government is in the process of designing a new medium-term action plan for public financial management (PFM) reform for 2008-2010. We expect the action plan to be finalized and approved by June, 30, 2008 (performance criterion), and it will be based on assessments in the public expenditure and financial accountability (PEFA) review that was completed recently. The PFM Action Plan should include the following elements:

(a) identification of the weaknesses of the current system, (b) a medium-term strategy to address these weaknesses, (c) the details of each specific component (description of activities, outputs, indicators, and responsibilities), (d) the expected outcomes at the end of the reform period, (e) the perceived risks and obstacles and how these will be addressed, (f) institutional implications, (g) interaction with other reforms (decentralization, civil service reform), (h) program management, funding, oversight, reporting, auditing, and review. Recognizing that a strong PFM system is important for the monitoring of financial resources provided through budget support, we will elaborate the plan in close consultation with development partners. Actions in 2008 will support human and institutional capacity building, the implementation of an integrated financial management information system, the reinforcement of the medium-term expenditure framework, and the completion of a debt management strategy. The action plan for 2008 will include measures in the following areas:

- Public accounts and budget execution. We will produce the execution reports of central government's transfers to local governments per program per district for July-December 2007 by March 31, 2008 and for the period January-June 2008 by September 30, 2008. We will prepare the consolidated fiscal report for 2007, including the central government, local governments, autonomous agencies, and extra-budgetary funds by June 2008.

- Budget Preparation. We will produce an operational manual for the medium-term expenditure framework by June 30, 2008 (performance criterion). The MTEF operational manual should explain the principles of priority setting and describe the main agents and the key steps in the budget preparation process, including the links connecting the macroeconomic framework, the macro-budgetary framework, and sectoral strategies.

- Debt Management. We will develop and publish a debt management strategy with clear limits for loans and guarantees that are consistent with the provisions in the Organic Budget Law by November 30, 2008 (benchmark). We will produce a draft to be submitted to the IMF for joint quality review.

- Internal audit. We will publish internal audit manuals by June 30, 2008. 
- Information and Communication Technology. To facilitate the implementation of an integrated financial management information system (IFMIS), we will complete an IFMIS strategy by November 2008.

- Public Procurement. We will complete a strategic plan for procurement, capacity building, and retention by October 2008.

\section{Monetary and Exchange Rate Policy}

18. To prevent the scaling up of spending from fueling inflation, the NBR will maintain a tight monetary policy. It will continue to monitor inflation, government spending and private sector credit and will stand ready to tighten the monetary stance, if needed.

19. The NBR will continue to use reserve money as the operational target to control inflation. To reduce average inflation to about 7 percent, it will limit year-end reserve money growth to 14 percent, which would create sufficient room for an expansion of credit to the private sector. The NBR will continue to follow closely inflationary developments and mop up excess liquidity, in particular through sales of foreign exchange.

20. We will allow more flexibility in the exchange rate. Acknowledging that an increase in spending from higher aid flows in 2008 is likely to result in further pressures for a real exchange rate appreciation, we will forcefully implement our intervention strategy. We will allow nominal appreciation by raising foreign exchange sales while smoothing short-term market fluctuations. This will ensure that the execution of the 2008 budget does not rekindle inflation or crowd out private investment. We will be guided by the recommendations of a forthcoming technical assistance mission from the IMF's Monetary and Capital Markets Department in our efforts to revitalize the foreign exchange market. This should enable us to step up foreign exchange sales.

21. The NBR will improve liquidity management. We recognize the limitations of overnight and 7-day instruments for money market operations. In this regard, we will reintroduce 4-week instruments and establish repurchase agreement operations ranging from 1 to 90 days in 2008. We will aim to restore interest rates for these instruments to positive levels in real terms. These changes will be done gradually and will be communicated to the financial sector in a timely manner so as to avoid disruptions in the financial markets arising from asymmetric information.

\section{We commit to formalizing the existing Treasury Management Committee}

(TMC). The TMC has been holding informal weekly meetings between the MoF and NBR to coordinate fiscal and monetary policy. It has provided an analytical platform to both institutions to refine policy implementation and forecasts.

\section{External Sector}

23. Owing to the increase in fiscal spending, we expect the external current account deficit (excluding official transfers) to widen to about 20 percent of GDP (about 
4 percent of GDP greater than 2007). Export receipts are projected to grow by at least 12 percent, driven mainly by increased volumes of traditional exports (particularly coffee) and continued growth in the tourism industry. The expected increase in imports by about 30 percent stems from an expansion in the fiscal deficit, the withdrawal of projects accounts, the commencement of the new energy project, and buoyant private sector activity.

24. The implementation of debt relief under the enhanced HIPC Initiative is at an advanced stage. In addition to IMF, IDA and AfDB, completion point and topping up assistance has been provided by BADEA and the OPEC Fund. IFAD, the Kuwait Fund, Fund, the Saudi Fund and the EU have already provided completion point assistance. Bilateral agreements have been signed with all Paris Club creditors. Regarding non-Paris Club creditors, China has cancelled all outstanding loans totaling about US\$32m, while Saudi Arabia and Kuwait indicated the possibility of future debt relief. Debt owned to Libya and the Abu Dhabi Fund continues to be in technical arrears.

25. Preparations for joining the EAC Customs Union intensified. Rwanda became a member of the East African Community on July 1, 2007. The necessary provisions for entrance into the custom union will be completed by June 2009. Laws requiring amendments have been identified. The list of sensitive products and raw materials as exemptions to the common external tariff has been compiled, while a study to determine the anticipated revenue loss is being undertaken. Rwanda has signed an interim agreement with the European Union to continue negotiations on an EPA. This interim agreement is in line with the EAC common position.

\section{B. Structural Policies}

26. The focus on the structural side will remain on enhancing the productivity of the agricultural and export sectors and improving the conditions for the private sector.

\section{Export promotion}

27. Our export promotion strategy will continue to focus on enhancing the productivity in the traditional sectors and diversifying our export base.

- Coffee. To improve yields, use will be made of industrial fertilizers and pesticides, for which training will be provided to farmers. To increase value added, the number of washing stations will be further increased, while existing stations are being made more efficient through increased training, improved water supply and upgrade of feeder roads. A Coffee Marketing Alliance will be established to improve marketing.

- $\quad$ Tea. To increase export volume and quality, efforts aimed at improving harvesting methods and expanding nursery beds and tea plantations will be intensified. To increase value added, a blending industry will be established, while efforts at direct marketing will be intensified to improve market prices.

- Tourism. A tourism master plan will be developed with the assistance of the World Tourism organization. Commencing in 2008, substantial inflows of FDI are expected in tourism related activities. This includes construction of a convention centre 
financed mainly by LAP Libya, and a golf hotel and executive suites financed by Dubai World.

- $\quad$ Export Processing Zone (EPZ). Rwanda's Free Zone Company Ltd. was established to fast track implementation of the EPZ. Expropriation of the land is now complete and technical studies are expected to be completed in early 2008.

\section{Financial sector}

28. The agenda for medium-term financial sector reform is based on our Financial Sector Development Plan, which was discussed with donors in early 2007. Our plans for 2008 include the following:

- Modernizing the national payments system. The draft decree for the establishment of the National Payments Council has been submitted to Cabinet for approval and will be constituted by June 30, 2008. It will be tasked with the responsibility for developing and implementing a National Payment Systems strategy to develop basic payments services targeted at the community at large, based primarily on electronic transfers. The NBR, in consultation with the East AFRITAC, has initiated the exercise and expects completion of the strategy by September 30, 2008 (benchmark).

- Developing long-term finance and capital markets. The Capital Market Advisory Council will operate as a self-regulatory organization and oversee an over-the-counter debt and equities market. We will pursue a number of initiatives to establish a robust legal, regulatory, and market infrastructure for securities over the medium term. We plan to inaugurate a government bond market by the first quarter of 2008 to establish a yield curve using one, two, three, five and seven year treasury bonds. Other operations for 2008 include the establishment of a corporate bond market.

- Contractual savings and investments. We plan to enact a Private Pension and Mutual Fund law to further strengthen the legal and regulatory framework to support the development of a market for (a) the contractual savings industry and (b) long-term saving and investment instruments.

\section{Cost of doing business}

29. We will make further efforts toward improving the business climate and removing obstacles to business development. The Rwanda Commercial and Registry Services will be made operational. The agency will provide a comprehensive registration system aimed at improving business registration, securitization of assets, and registration of intellectual property rights. The office of the Registrar of Land Titles will become operational in 2008 , thereby simplifying the land registration process.

\section{Program Monitoring}

30. Conditionality and program reviews. The fourth review under the PRGF arrangement, scheduled for completion by June 2008, will review quantitative performance as of end-December 2007, and structural conditionality through end-December 2007. The third 
year of the PRGF-supported program will be monitored through quantitative performance criteria for end-June and end-December 2008 and indicative targets for end-March and endSeptember 2008, as well as quarterly quantitative indicators. We have also set structural conditionality in tax administration, public expenditure management, and financial sector reforms (Table 4). The fifth and sixth program reviews will be completed no later than endNovember 2008 and end-May 2009 respectively.

31. Technical memorandum of understanding (TMU). The attached TMU lays out the details of the program design and terminology. We have maintained the broad design of the program for 2007, but have added an adjustor to reserve money with respect to inclusion of UBPR as a commercial bank and have simplified the adjusters relating to aid shortfalls, to help insulate the budget in the event of minor deviations in aid flows. 
Table 1. Rwanda: Quantitative Performance Criteria and Benchmarks for 2007 (RF billions, unless otherwise indicated)

(Quantitative benchmarks* and performance criteria on test dates**)

\begin{tabular}{|c|c|c|c|c|}
\hline & Mar.* & Jun. ${ }^{\star *}$ & Sep.* & ${\text { Dec. }{ }^{* *}}^{*}$ \\
\hline \multicolumn{5}{|l|}{ Benchmarks and performance criteria } \\
\hline $\begin{array}{l}\text { Net foreign assets of the NBR (floor on stock) } \\
\text { Actual (program exchange rate) } \\
\text { Adjusted program } \\
\text { Program }\end{array}$ & $\begin{array}{l}289.3 \\
238.2 \\
208.1\end{array}$ & $\begin{array}{l}268.2 \\
234.7 \\
244.3\end{array}$ & $\begin{array}{l}294.7 \\
196.5 \\
206.8\end{array}$ & $\begin{aligned} \cdots \\
179.3\end{aligned}$ \\
\hline $\begin{array}{l}\text { Reserve money (ceiling on stock) }{ }^{2} \\
\text { Actual } \\
\text { Program }\end{array}$ & $\begin{array}{l}78.4 \\
72.4\end{array}$ & $\begin{array}{l}81.8 \\
83.0\end{array}$ & $\begin{array}{l}87.4 \\
88.1\end{array}$ & 87.9 \\
\hline $\begin{array}{l}\text { Net credit to the government (ceiling on flow) } \\
\text { Actual } \\
\text { Adjusted program } \\
\text { Program }\end{array}$ & $\begin{array}{r}22.1 \\
-11.5 \\
-11.5\end{array}$ & $\begin{array}{l}-45.4 \\
-28.1 \\
-37.7\end{array}$ & $\begin{array}{r}-9.5 \\
-19.4 \\
-25.7\end{array}$ & $\begin{array}{r}\cdots \\
\cdots \\
4.7\end{array}$ \\
\hline $\begin{array}{l}\text { Domestic fiscal balance (floor on flow) })^{3,4} \\
\text { Actual } \\
\text { Adjusted program } \\
\text { Program }\end{array}$ & $\begin{array}{l}-21.5 \\
-21.1 \\
-21.1\end{array}$ & $\begin{array}{l}-35.2 \\
-53.9 \\
-64.9\end{array}$ & $\begin{array}{l}-79.6 \\
-65.7 \\
-70.6\end{array}$ & $\begin{array}{r}\cdots \\
-98.7\end{array}$ \\
\hline $\begin{array}{l}\text { Total priority spending (floor on flow) } \\
\text { Actual } \\
\text { Adjusted program } \\
\text { Program }\end{array}$ & $\begin{array}{l}41.6 \\
33.1 \\
38.6\end{array}$ & $\begin{array}{l}87.7 \\
81.2 \\
86.7\end{array}$ & $\begin{array}{l}152.3 \\
123.6 \\
132.4\end{array}$ & $\begin{array}{r}\cdots \\
181.1\end{array}$ \\
\hline $\begin{array}{l}\text { New nonconcessional external debt } \\
\text { Actual } \\
\text { Program }\end{array}$ & $\begin{array}{l}0.0 \\
0.0\end{array}$ & $\begin{array}{l}0.0 \\
0.0\end{array}$ & $\begin{array}{l}0.0 \\
0.0\end{array}$ & 0.0 \\
\hline $\begin{array}{l}\text { New external payment arrears (ceiling on stock) } 5,6 \\
\text { Actual } \\
\text { Program }\end{array}$ & $\begin{array}{l}0.0 \\
0.0\end{array}$ & $\begin{array}{l}0.0 \\
0.0\end{array}$ & $\begin{array}{l}0.0 \\
0.0\end{array}$ & 0.0 \\
\hline $\begin{array}{l}\text { Short-term external debt (ceiling on stock) } \\
\text { Actual } \\
\text { Program }\end{array}$ & $\begin{array}{l}0.0 \\
0.0\end{array}$ & $\begin{array}{l}0.0 \\
0.0\end{array}$ & $\begin{array}{l}0.0 \\
0.0\end{array}$ & 0.0 \\
\hline $\begin{array}{l}\text { Net accumulation of domestic arrears (ceiling on flow) }{ }^{3} \\
\text { Actual } \\
\text { Program }\end{array}$ & $\begin{array}{l}-1.6 \\
-1.6\end{array}$ & $\begin{array}{l}-3.9 \\
-3.9\end{array}$ & $\begin{array}{r}3.6 \\
-5.4\end{array}$ & $-7 . \overline{-}$ \\
\hline Indicative targets & & & & \\
\hline $\begin{array}{l}\text { Broad money (ceiling on stock) } \\
\text { Actual } \\
\text { Program }\end{array}$ & $\begin{array}{l}277.3 \\
254.5\end{array}$ & $\begin{array}{l}306.1 \\
297.7\end{array}$ & $\begin{array}{l}331.8 \\
305.3\end{array}$ & 312.4 \\
\hline $\begin{array}{l}\text { Extended broad money (ceiling on stock) }{ }^{1} \\
\text { Actual } \\
\text { Program }\end{array}$ & $\begin{array}{l}324.7 \\
290.9\end{array}$ & $\begin{array}{l}356.7 \\
346.2\end{array}$ & $\begin{array}{l}388.7 \\
355.0\end{array}$ & 363.3 \\
\hline $\begin{array}{l}\text { Net Present Value of the Stock of Outstanding Debt (Millions of US } \$ \\
\text { End-December } 2007-- \text { Actual } \\
\text { End-December } 2008-- \text { Actual } \\
\text { End-December 2009--Actual } \\
\text { End-December 2007--Program } \\
\text { End-December 2008--Program } \\
\text { End-December 2009--Program }\end{array}$ & & $\begin{array}{l}200.4 \\
239.8 \\
279.0\end{array}$ & & $\begin{array}{l}200.4 \\
239.8 \\
279.0\end{array}$ \\
\hline $\begin{array}{l}\text { Ceiling on stock of domestic debt } \\
\text { Actual } \\
\text { Adjusted program } \\
\text { Program }\end{array}$ & & $\begin{array}{l}165.3 \\
184.8 \\
175.2\end{array}$ & $\begin{array}{l}180.0 \\
188.5 \\
187.1\end{array}$ & $\begin{array}{r}-- \\
185.1\end{array}$ \\
\hline $\begin{array}{l}\text { Memorandum items: } \\
\text { General budget support (Millions of US } \$)^{4,10}\end{array}$ & & & & \\
\hline $\begin{array}{l}\text { Received } \\
\text { Expected } \\
\text { Of which: budget support grants (received) } \\
\text { Of which: budget support grants (expected) } \\
\text { Budgetary "baseline grants" (TMU, para. } 9)^{10} \\
\text { Revised domestic fiscal balance (excluding } A U \text {, demob and food) }{ }^{1}\end{array}$ & $\begin{array}{r}5.8 \\
65.2 \\
5.8 \\
65.2 \\
60.2\end{array}$ & $\begin{array}{l}159.5 \\
186.5 \\
159.0 \\
186.5 \\
176.5 \\
-43.3 \\
\end{array}$ & $\begin{array}{l}177.7 \\
193.0 \\
175.4 \\
193.0 \\
178.0 \\
-65.1 \\
\end{array}$ & $\begin{array}{r}196.6 \\
-- \\
196.6 \\
176.6 \\
-93.2 \\
\end{array}$ \\
\hline $\begin{array}{l}\text { Sources: Rwandese authorities and IMF staff estimates and proje } \\
{ }^{1} \text { At the program exchange rate of RF } 549.9 / \text { US } \$ \text { for } 2007 \text {. } \\
2 \text { Targets are calculated as an arithmetic average of the stock of reserve } \\
\text { quarter. Program projections are done quarterly. To derive the monthly figu } \\
\text { quarterly projections. The seasonality factors are derived by applying the } X \\
\text { factors were robust with respect to different time periods). The seasonality } \\
1.0 \text { for July, } 0.98 \text { for August, } 0.96 \text { for September, } 0.94 \text { for October, } 0.94 \text { for } \\
{ }^{3} \text { Numbers are cumulative from December } 31,2006 \text {. }\end{array}$ & $\begin{array}{l}\text { ey on the } \\
\text { seasona } \\
\text { ter to cu } \\
\text { rs were } \\
\text { ember a }\end{array}$ & $\begin{array}{l}\text { day of ea } \\
\text { tors and } \\
\text { in circul } \\
\text { for April, } \\
\text { for Dece }\end{array}$ & $\begin{array}{l}\text { endar mo } \\
\text { d are ap } \\
\text { ver } 2002 \\
\text { May, } 1 .\end{array}$ & $\begin{array}{l}\text { the } \\
\text { o the } \\
\text { he } \\
\text { June, }\end{array}$ \\
\hline $\begin{array}{l}{ }^{4} \text { The domestic fiscal balance targets will be adjusted by the amount of gr } \\
\text { adjusters as specified in the TMU of January } 10,2007, \text { and paragraph } 3 \text { of } \\
\text { targets will be adjusted by the amount of grants exceeding or below prograt } \\
5 \text { This is a continuous performance criterion. } \\
{ }^{6} \text { Excludes arrears on obligations that are subject to rescheduling. }\end{array}$ & $\begin{array}{l}\text { exceedir } \\
\text { d gu of } \\
\text { d grants }\end{array}$ & 2007. & priority & the \\
\hline $\begin{array}{l}{ }^{7} \text { Ceiling on the stock of external debt (excluding normal imported-related } \\
\text { governments, local government, or the NBR with original maturity of up to, } \\
8 \text { Figures indicate the NPV projections based on debt contracted at the te } \\
9 \text { Numbers show end of period stocks, at the end of } 2006 \text { the stock stood } \\
{ }^{10} \text { Excluding external donor financing for demobilization and peacekeeping }\end{array}$ & $\begin{array}{l}\text { lits) owe } \\
\text { ncluding } \\
\text { te. } \\
\text { F } 189.6\end{array}$ & $\begin{array}{l}\text { uarantee } \\
\text { year. }\end{array}$ & e centra & \\
\hline
\end{tabular}


Table 2. Rwanda: Quantitative Performance Criteria and Benchmarks for 2008 (RF billions, unless otherwise indicated)

(Quantitative benchmarks* and performance criteria on test dates ${ }^{\star *}$ )

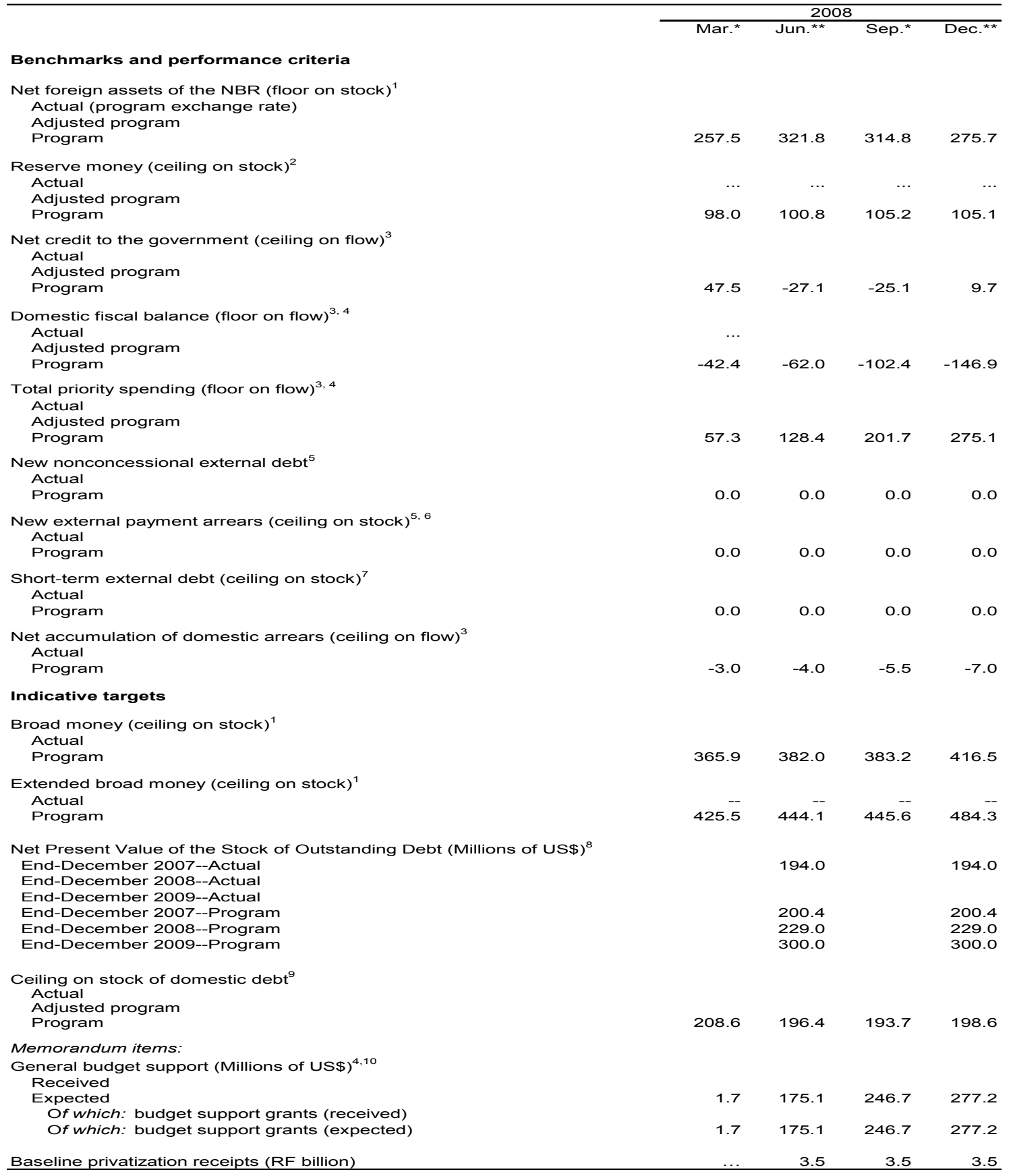

Sources: Rwandese authorities and IMF staff estimates and projections.

1 At the program exchange rate of RF545/US\$ for 2008.

${ }^{2}$ Targets are calculated as an arithmetic average of the stock of reserve money on the last day of each calendar month in the quarter. Program projections are done quarterly.

${ }^{3}$ Numbers are cumulative from December 31, 2006.

${ }^{4}$ The domestic fiscal balance targets will be adjusted by the amount of grants exceeding or below programmed grants with the adjusters as specified in the TMU of January 10, 2007, and paragraph 3 of the TMU of June 7, 2007. Also the priority spending targets will be adjusted by the amount of grants exceeding or below programmed grants.

${ }^{5}$ This is a continuous performance criterion.

${ }^{6}$ Excludes arrears on obligations that are subject to rescheduling.

${ }^{7}$ Ceiling on the stock of external debt (excluding normal imported-related credits) owed or guaranteed by the central

governments, local government, or the NBR with original maturity of up to, and including one year.

${ }^{8}$ Figures indicate the NPV projections based on debt contracted at the test date.

${ }^{9}$ Numbers show end of period stocks, at the end of 2006 the stock stood at RF 189.6 billion.

${ }^{10}$ Excluding external donor financing for demobilization and peacekeeping. 
Table 3. Rwanda: Structural Conditionality, 2007

\begin{abstract}
Public expenditure management
Issue draft accounting instructions, forms, and procedures for budget users.

Complete progress report on financial reporting by budgetary agencies (line ministries, provinces, autonomous agencies). Agencies are expected to produce the following monthly financial reports: (i) bank reconciliation statement; (ii) budget execution reports, and (iii) statements of revenue and expenditure.

Publish on the Ministry of Finance's website the first consolidated execution report of local governments showing transfers and budget execution per major line items per district and per province for the period January-April.

Complete and publish on the Ministry of Finance's website a study on project accounts (for projects listed in paragraph 46 of the TMU) at the NBR (1) showing annual budgets with donor disbursements and spending for 2004-2006 as well as quarterly projections (including a breakdown into imports and the domestic component) for July 2007June 2008; and (2) providing an analysis of the causes for the large accumulation of the specific project accounts since January 1, 2004.

Publish on the Ministry of Finance's website the progress report on the implementation of the Organic Budget Law.
\end{abstract}

\section{Civil service reform}

Undertake a comprehensive review of the wage structure of the public sector, including fringe benefits and wages included in transfers to local governments.

\section{Private sector development}

Make operational the Office of the Registrar of Land Titles.

\section{Poverty reduction}

Produce a poverty profile of provinces, districts, and communities of Rwanda using the results of the census and the household living conditions survey.

\section{Financial sector}

Submit to Parliament a micro finance law to bring the legal framework for microfinance broadly in line with the Guiding Principles on

Regulation and Supervision of Microfinance Institutions as published by the Consultative Group to Assist the Poorest.

\section{Agricultural sector}

Adopt and publish a national fertilizer distribution strategy.

$\begin{array}{lll}\begin{array}{l}\text { December } \\ \text { 31, } 2006\end{array} & \text { Benchmark } & \begin{array}{l}\text { Not met. Implemented in } \\ \text { May } 2007 .\end{array} \\ \begin{array}{l}\text { June 15, } \\ 2007\end{array} & \text { Benchmark } & \begin{array}{l}\text { Not met. Completed in } \\ \text { September 2007. }\end{array}\end{array}$

\section{July 31 , 2007}

September 30,2007

September 30,2007

September 30,2007

October 31, 2007

September 30, 2007

June 30, 2007
Benchmark Performance Criterion- for the completion of the third review

Performance Criterion- for the completion of the third review

Benchmark

Met.

Not met. Completed in October 2007
Not met. Report covering districts only published on July 31, 2007. Report on provinces published in October 2007.

Met.
Benchmark

Met.

Benchmark

Not met. Report was produced for provinces only.

Benchmark Met.
February 28, Benchmark 2007
Not met. Implemented in April 2007. 
Table 4. Rwanda: Structural Conditionality, 2008

Public Expenditure Management

Complete and publish on MINECOFIN website a revised PFM reform action plan for 2008-2010, as specified in paragraph 17 of the MEFP.

Produce and publish on the MINECOFIN website the MTEF operational manual, as specified in paragraph 17 of the MEFP.

Develop and publish on the MINECOFIN website a debt management strategy (DMF) with clear limits for loans and guarantees that are consistent with the provisions in the Organic Budget Law.

\section{Tax Administration}

Develop and publish on the RRA website a comprehensive compliance program which identifies key compliance risks associated with the large, medium, and small taxpayer segments, together with a description of the planned RRA initiatives to address the identified risks based on risk analysis.

Implement an expedited clearance scheme (super green/gold card) for compliant importers contributing a cumulative 60 percent of import taxes.

\section{Financial Sector}

Publish on the NBR's website a national payments strategy to improve the payments infrastructure and address the development of basic payment services in Rwanda.
Target date

June 30, 2008

June 30, 2008

November 30 ,

2008

June 30, 2008

Benchmark

June 30, 2008

Benchmark

September 30, Benchmark 2008
Benchmark

Macro Rationale

condition

Performance criterion

Performance criterion

To reinforce the MTEF process and facilitate and harmonize the preparation of the MTEF by sectoral ministries, thereby improving the coordination and management of the budget over the medium term.

To provide guidance for future borrowing decisions and prevent the reaccumulation of unsustainable debt.
To raise efficiency of tax collection, improve overall tax compliance, and widen the tax base, thereby reinforcing fiscal sustainability over the medium term.
To reduce customs clearance time, improve the level of trade facilitation, and reduce inventory costs, thereby facilitating private sector development.
To promote the development of a stable financial system by reducing high transaction costs for businesses, and financial risks in payment clearance and settlements. 


\section{APPEndix I-ATtachment II}

\section{RWANDA-TECHNICAL MEMORANDUM OF UNDERSTANDING}

February 12, 2008

1. This technical memorandum sets out the definitions for quantitative targets under which Rwanda's performance will be assessed and provides specifics on areas of structural conditionality. Monitoring procedures and reporting requirements as well as other program definitions are also specified.

\section{Quantitative Program Targets}

2. Performance criteria for June 30, 2008 and December 31, 2008 as well as indicative targets for March 31, 2008, and September 30, 2008 are proposed to be established with respect to:

- $\quad$ floors on the domestic fiscal balance of the central government (DFB);

- $\quad$ ceilings on the net credit to the central government (NCG);

- $\quad$ floors on priority spending;

- $\quad$ ceilings on the net accumulation of domestic arrears of the central government;

- $\quad$ floors on the Net Foreign Assets (NFA) of the National Bank of Rwanda (NBR);

- $\quad$ ceilings on reserve money; and

- ceilings on the outstanding stock of external debt with original maturities of one year or less owed or guaranteed by the public sector.

3. Performance criteria that are applicable on a continuous basis are proposed to be established with respect to the ceilings on new external payment arrears of the public sector and new nonconcessional debt of the public sector.

4. Indicative targets are proposed to be established

- $\quad$ for end-March 2008, end-June 2008 end-September 2008, and end-December 2008, for ceilings on broad money and extended broad money;

- for end-June 2008, and end-December 2008, for ceilings on the contracting or guaranteeing of concessional external debt. 
- $\quad$ for end-March 2008, end-June 2008 end-September 2008, and end-December 2008 for ceilings on the consolidated domestic debt of the public sector.

\section{A. Institutional Definitions}

5. The central government comprises the treasury and line ministries.

6. The public sector comprises the central government, local governments, public enterprises (including Electrogaz, Ocircafé, Ocirthé, Prime Holdings, and ONP), and the NBR.

\section{B. Targets related to the Execution of the Fiscal Program}

\section{Domestic Fiscal Balance of the Central Government (DFB)}

7. A floor applies to the DFB, which is measured cumulatively from December 31, 2007 for the end-March 2008, end-June, 2008, end-September 2008 and end-December 2008 targets.

8. Definition. The domestic fiscal balance (Table 2 of the MEFP) is defined as domestic revenue (excluding grants) minus domestic spending. Domestic spending is defined as current expenditure (excluding external interest due, spending related to Rwandese troops involved in the UN peace-keeping efforts, and spending related to the World Bank-led demobilization and reintegration program) plus domestically-financed capital expenditure on a payment order basis, plus net lending.

\section{Adjusters.}

- $\quad$ The floor on the DFB will be adjusted downward (i.e., the deficit target will be increased) in the context of a review with Fund staff, by the amount of the cumulative positive difference between actual and programmed budgetary grants (defined in Table 2 of the MEFP), up to a maximum of RF 11 billion, IF this review establishes that a further fiscal expansion would not lead to a rekindling of inflation or an undue increase in domestic debt. The increase in the deficit would be used for contingent spending, a list of which is provided in Table 1. Budgetary grants include HIPC Initiative-related grants, ${ }^{1}$ but exclude grants related to AU peace keeping activities and for the demobilization program as well as capital grants related to the development budget. Quarterly programmed budgetary grants are also provided in Table 2 of the MEFP.

\footnotetext{
${ }^{1}$ HIPC grants exclude debt relief from IDA and the AfDB.
} 
- $\quad$ The floor on the DFB will be adjusted upward (that is, the deficit target will be reduced) by the amount of any shortfall between actual and programmed budgetary grants (defined in Table 2 of the MEFP) which exceeds the equivalent of US\$24 million, evaluated in Rwanda francs at the program exchange rate.

- $\quad$ The floor on the DFB will be adjusted downward (i.e., the deficit target will be increased) by the amount of expenditure deemed integral to a specific privatization operation (to be recorded under net lending) IF the difference between privatization revenue and this expenditure is positive (see also paragraph 13).

- The floor on the DFB will be adjusted downward (i.e., the deficit target will be increased) by the amount of expenditure for food imports in the case of a food emergency (see also paragraphs 13 and 24).

10. Reporting requirement. Data on the DFB and its adjusters will be transmitted, with detailed explanations, on a monthly basis within four weeks of the end of each month.

\section{Net Credit to the Central Government (NCG)}

11. A ceiling applies to the NCG, which is measured cumulatively from December 31 , 2007 for the end-March 2008, end-June 2008, end-September 2008, and end-December 2008 targets.

12. Definition. For program monitoring purposes, the NCG will be calculated as the change from end-December 2007 of net credit from the banking system and the change of holdings of treasury bills and other government securities by the nonbank sector. Net credit from the banking system is defined as the difference between:

- $\quad$ credit to government from the banking system, including credit to central government, provinces and districts, outstanding consolidated central government debt instruments; including government debt to the NBR incurred as a result of the 1995 devaluation (Rf 9 billion) and the overdraft to the prewar government ( Rf 2 billion); and

- $\quad$ total government deposits with the banking system of the central government, including the main treasury account, line ministries, the fund for assistance to genocide survivors, Rwanda Revenue Authority, the electoral commission, the demobilization commission, fonds routier, the privatization account, and any other of the 15 autonomous agencies. Thus, this definition excludes any government deposits, over which the central government does not have any direct control (i.e., for project accounts, counterpart funds and fonds publics affectés). ${ }^{2}$ In particular, NCG is not

\footnotetext{
${ }^{2}$ The target excludes any transfers from the deposits over which the government has limited control into other government deposits.
} 
affected by credit to or deposits of public enterprises and autonomous public agencies.

\section{Adjusters.}

- $\quad$ The ceiling on NCG will be adjusted upward by the amount of any shortfall between actual and programmed budgetary grants (defined in Table 2 of the MEFP). This adjustment will be capped at the equivalent of US\$24 million, evaluated in Rwanda francs at the program exchange rate.

- $\quad$ The ceiling on the NCG will be adjusted downward by the amount of privatization revenue in excess of programmed amounts, as defined in Table 2 of the MEFP, less any expenditure deemed integral to the privatization operation, provided that the excess revenue is positive net of such expenditure.

- $\quad$ The ceiling on the NCG will be adjusted upward by the amount of expenditure for food imports in case of a food emergency (see also paragraph 9 and 24).

14. Reporting requirement. Data on the NCG (showing separately treasury bills and government bonds outstanding, other government debt, and central government deposits) and its adjusters will be transmitted on a monthly basis within three weeks of the end of each month. Deposits of the government with the NBR and with the commercial banks will be separated from the deposits of the public enterprises and autonomous public agencies.

\section{Priority Expenditure}

15. A floor applies to priority spending of the central government, which is measured cumulatively from December 31, 2007 for the end-March 2008, end-June 2008, endSeptember 2008, and end-December 2008 targets.

16. Definition. Central government priority spending is defined as the sum of those recurrent expenditures, domestically-financed capital expenditures, and net lending that the government has identified as priority in line with the PRSP process. The definition of priority expenditures is based on the program classification of the annual budget. Table 2 provides a summary of the SIBET output ${ }^{3}$ and a list of the main programs.

17. Adjuster. The floor will be adjusted (upward or downward) by an amount equal to half of any adjustment in the DFB floor as specified in paragraph 9.

18. Reporting requirement. Data on priority expenditure, at the same level of detail as in Table 2, will be transmitted on a monthly basis within three weeks of the end of each month.

\footnotetext{
${ }^{3}$ The computerized SIBET expenditure management system tracks priority spending at the program level.
} 


\section{Net Accumulation of Domestic Arrears of the Central Government}

19. A ceiling applies to the net accumulation of domestic arrears of the central government, which is measured cumulatively from December 31, 2007 for the end-March 2008, end-June 2008, end-September 2008, and end-December 2008 targets. $^{4}$

20. Definition. The net accumulation of arrears is defined as the difference between the gross accumulation of new domestic arrears (measured as the difference between payment orders and actual payments related to payment orders issued) and gross repayment of any arrears outstanding on December 31, 2007 (including repayment of float in 2007 and the repayment of older arrears).

21. Reporting requirement. Data on repayment of domestic arrears and the remaining previous-year stock of arrears will be transmitted on a monthly basis within three weeks of the end of each month.

\section{Domestic debt of the central government and the National Bank of Rwanda (DD)}

22. A ceiling applies to the DD for the end-June 2008, end-September 2008, and endDecember 2008 targets.

23. Definition. Domestic debt of the central government and the National Bank of Rwanda includes the stock of treasury bills for government financing at coupon value, plus government borrowing from public enterprises (FinaBank formerly Bank Continental Africaine du Rwanda, Bank Commerciale du Rwanda, Bons de Developpement, Credit Savings Scheme, Caisse Social du Rwanda, OCIR-Thé; and rescheduling of old arrears) plus the stock of treasury bills issued for monetary policy, plus any one-day or one-week deposits of commercial banks at the central bank excluding excess and required reserves. ${ }^{5}$

\section{Adjusters}

- To allow for sterilization of a grant-financed reduction in the domestic fiscal balance (increase in the deficit), the ceiling on domestic debt will be adjusted upward by onethird of any reduction in the floor on DFB provided for in paragraph 9.

- In the case of a shortfall in grants, for which an automatic adjuster would increase the limit on net credit to government, the ceiling on domestic debt will be adjusted upward by the same amount as the increase in the ceiling on net credit to government.

\footnotetext{
${ }^{4}$ A negative target thus represents a floor on net repayment.

${ }^{5}$ T-bill holdings of the NBR are excluded because this is the consolidated debt of the central government and the NBR.
} 
25. Reporting requirement. Data on domestic debt will be transmitted on a monthly basis within four weeks of the end of each month.

\section{Targets for Monetary Aggregates}

\section{Net Foreign Assets of the National Bank of Rwanda (NFA)}

26. A floor applies to the NFA of the NBR for the end-March 2008, end-June 2008, endSeptember 2008, and end-December 2008 targets.

27. Definition. NFA of the NBR in Rwanda francs are defined, consistent with the definition of the Special Data Dissemination Standards (SDDS) template, as external assets readily available to, or controlled by, the NBR net of its external liabilities. Pledged or otherwise encumbered reserve assets are to be excluded; such assets include, but are not limited to, reserve assets used as collateral or guarantee for third party external liabilities. Foreign assets and foreign liabilities in U.S. dollars are converted to Rwanda francs by using the U.S. dollar/Rwanda franc program exchange rate. ${ }^{6}$ Foreign assets and liabilities in other currencies are converted to U.S. dollars by using the actual end-of-period U.S. dollar/currency exchange rate. Foreign liabilities include, inter alia, use of IMF resources (CCFF and post-conflict emergency assistance purchases and SAF/ESAF/PRGF disbursements).

\section{Adjusters}

- $\quad$ The floor on NFA will be adjusted downward by the amount of any shortfall between actual and programmed budgetary grants. This adjustment will be capped at the equivalent of US\$24 million, evaluated in Rwanda francs at the program exchange rate.

- $\quad$ The floor on NFA will be adjusted downward by the amount of expenditure for food imports in the case of a food emergency (see also paragraphs 9 and 13).

29. Reporting requirement. Data on foreign assets and foreign liabilities of the NBR will be transmitted on a weekly basis within seven days of the end of each week. Data on the NBR's foreign exchange liabilities to commercial banks (held as required reserves with the NBR) and the exchange rate used for their conversion into Rwanda francs will be shown separately.

\footnotetext{
${ }^{6}$ The program exchange rate for the 2008 program is set at Rf545 $=$ US $\$ 1$.
} 


\section{Reserve Money}

30. A ceiling applies to the stock of reserve money for the end-March 2008, end-June 2008, end-September 2008, and end-December 2008 targets. The stock of reserve money for the quarter will be calculated as the arithmetic average (mean) of the stock of reserve money at the last day of each calendar month comprising the quarter.

31. Definition. Reserve money for the monetary program is defined as currency in circulation, reserves of deposit money banks (excluding NBR borrowing from deposit money banks on the money market ${ }^{7}$ but including cash in vault held by commercial banks), and deposits of public enterprises (including Caisse Sociale du Rwanda (CSR) and other autonomous public agencies (dépôts des établissements publics assimilés à l'état), deposits of nonbank financial institutions, and deposits of the private sector (autres sommes dues à la clientele are included in reserve money). Reserve money excludes the deposits of the Caisse d'Épargne du Rwanda (C.E.R.) with the NBR up to Rf 1 billion, the dormant accounts up to Rf 1.4 billion, and import deposits placed at the NBR (cautions à l'importation) up to a maximum amount of Rf 150 million.

\section{Adjuster}

- $\quad$ The ceiling on the stock of reserve money will be adjusted symmetrically for a change in the required reserve ratio of commercial banks by the amount of (new reserve ratio - program baseline reserve ratio) multiplied by the reservable deposit liabilities in commercial banks.

- $\quad$ The ceiling on the stock of reserve money will be adjusted upwards to include the incorporation of the Union de Bank Populaires du Rwanda (UBPR) as a commercial bank. The magnitude of the upward adjustments will include the sum of (a) the stock of the arithmetic average (mean) of the stock of required reserves of the UBPR at the last day of each calendar month comprising the quarter and (b) the amount of Rf 0.4 billion required for prudential clearings. The adjustment will be made effective from the day of the UBPR incorporation.

33. Reporting requirement. Data on reserve money will be transmitted on a weekly basis within seven days of the end of each week. This transmission will include a weekly balance sheet of the NBR which will show all items listed above in the definitions of reserve money.

\footnotetext{
${ }^{7}$ Borrowing by the NBR from the commercial banks on the money market is included under the net domestic assets of the NBR (netted out from commercial bank borrowing from the NBR).
} 


\section{Broad Money}

34. A ceiling applies to the stock of broad money and extended broad money for the endMarch 2008, end-June 2008, end-September 2008, and end-December 2008 targets.

35. Definition. Broad money is defined as the sum of currency in circulation, deposits in commercial banks, and nonbank deposits in the NBR. Extended broad money is defined as broad money plus deposits in credit unions and credit cooperatives (mainly UBPR).

36. Reporting requirement. The balance sheets of the commercial banks and other banking institutions, both for the individual institutions and for the respective sector in aggregate, and the monetary survey, will be transmitted monthly within five weeks of the end of each month. The monthly transmission will also include a monthly balance sheet for the NBR, showing all items as in NBR's weekly balance sheet.

\section{Limits on External Debt}

\section{Limit on short-term external debt of the public sector}

37. A zero ceiling applies to the outstanding stock of external debt with original maturities of one year or less owned or guaranteed by the public sector or other agencies on behalf of the central government. The ceiling is measured cumulatively from December 31, 2007 for the end-March 2008, end-June 2008, end-September 2008, and end-December 2008 targets.

38. Definition. The definition of "debt", for the purpose of the limit, is set out in point No. 9 of the Guidelines on Performance Criteria with Respect to Foreign Debt (Decision No. 12274-(00/85) of August 24, 2000) and also commitments for which value has not been received. Excluded from this performance criterion are normal import-related credits, defined as liabilities that arise from the direct extension, during the normal course of trading, of credit from a supplier to a purchaser - that is, when payment of goods and services is made at a time that differs from the time when ownership of the underlying goods or services changes. Normal import credit arrangements covered by this exclusion are self-liquidating; they contain pre-specified limits on the amounts involved and the times at which payments must be made; they do not involve the issuance of securities.

39. Valuation. The amount of debt will be evaluated at the corresponding quarterly exchange rates published in the IMF's International Financial Statistics.

40. Reporting requirement: Data on debt and guarantees will be transmitted, with detailed explanations, on a monthly basis within five weeks of the end of each month. 


\section{Contracting or Guaranteeing of new nonconcessional external debt of the public sector}

41. The public sector or other agencies on behalf of the central government will not contract or guarantee new nonconcessional external debt ${ }^{8}$ (as specified in paragraphs 39 and 40) with original maturity of more than one year. This is a continuous performance criterion.

42. Valuation. The amount of debt will be evaluated at the corresponding quarterly exchange rates published in the IMF's International Financial Statistics.

43. Definition. This performance criterion applies to debt as defined in point No. 9 of the Guidelines on Performance Criteria with Respect to Foreign Debt (Decision No. 12274$(00 / 85)$ of August 24,2000$)$ and also to commitments contracted or guaranteed for which value has not been received. The use of Fund resources are excluded from the criterion. Included are leases and other instruments giving rise to external liabilities, contingent or otherwise.

44. For program purposes, a debt is concessional if it includes a grant element of at least 50 percent, calculated as follows: the grant element of a debt is the difference between the net present value (NPV) of debt and its nominal value, expressed as a percentage of the nominal value of the debt (i.e., the grant element is equal to the nominal value minus NPV divided by the nominal value). The NPV of debt at the time of its disbursement is calculated by discounting the future stream of payments of debt service due on this debt. The discount rates used for this purpose are the currency-specific commercial interest reference rates (CIRRs), as published by the OECD. For debt with a maturity of at least 15 years, the tenyear average CIRR will be used to calculate the NPV of debt and, hence, its grant element. For debt with maturity of less than 15 years, the six-month average CIRR will be used. To both the 10-year and the 6-month averages, the following margins for differing repayment periods should be added: 0.75 percent for repayment periods of less than 15 years; 1 percent for 15-19 years; 1.15 percent for 20-29 years; and 1.25 percent for 30 years or more.

45. Reporting requirement. Data on all new external debt, including government guarantees, will be provided on a monthly basis within five weeks of the end of each month.

\section{Contracting or guaranteeing of concessional external debt}

46. A ceiling applies to the contracting or guaranteeing of concessional (see paragraph 40) external debt of the public sector or other agencies on behalf of the central government for the end-June 2008, and end-December 2008 targets. The ceiling on the contracted debt becomes binding through a disbursement profile over 2007-09.

\footnotetext{
${ }^{8}$ As the performance criterion refers to "new" debt, rescheduling or restructuring of existing debt is excluded.
} 
47. Definition and valuation. The ceiling on the contracting or guaranteeing of new concessional external debt will be measured by the U.S. dollar nominal sum of all loan agreements that have been contracted. Disbursed debt will be converted to U.S dollars, based on prevailing WEO test date exchange rates; for loans contracted but not yet disbursed, the profile disbursement will be measured at the actual exchange rate at the test date, based on the projected drawdown consistent with the medium-term fiscal framework as discussed with IMF staff. The Net Present Value of debt is calculated by discounting the future stream of payments of debt service due, based on a uniform discount rate of 5 percent.

48. Reporting requirement. Data on the NPV of the stock of outstanding debt will be provided on a semi-annual basis within five weeks of the end of each month.

\section{Limit on new external payment arrears}

49. A continuous performance criterion applies to the nonaccumulation of new external payment arrears on external debt contracted or guaranteed by the public sector. External payment arrears consist of external debt service obligations (principal and interest) that have not been paid at the time they are due, as specified in the contractual agreements, but shall exclude arrears on obligations that are subject to rescheduling.

\section{Other Data requirements for Program Monitoring}

50. Other data will be reported on a regular basis for surveillance purposes (see Table 3). 
Table 1. Contingent spending, 2008 (in billion of Rwandese franc)

$\begin{array}{lr}\text { Priority spending } & \mathbf{5 . 2 0} \\ \text { Common development fund } & 1.00 \\ \text { Export Free Zone } & 0.20 \\ \text { Road Fund HER } & 3.00 \\ \text { Export promotion } & 1.00\end{array}$

$\begin{array}{lr}\text { Nonpriority spending } & 5.80\end{array}$

$\begin{array}{ll}\text { Construction of various offices } & 0.40\end{array}$

$\begin{array}{ll}\text { Youth and Culture } & 0.90\end{array}$

$\begin{array}{ll}\text { Feasibility studies } & 1.00\end{array}$

$\begin{array}{ll}\text { Across the board cuts in goods and services } & 2.00\end{array}$

$\begin{array}{ll}\text { Across the board cuts in transfers } & 1.50\end{array}$

$\begin{array}{lr}\text { Total } & 11.00\end{array}$

Source: Rwandese authourities 
Table 2. Priority Spending Excluding Contingency, 2008 (In million of Rwanda Francs)

BUDGET 2008

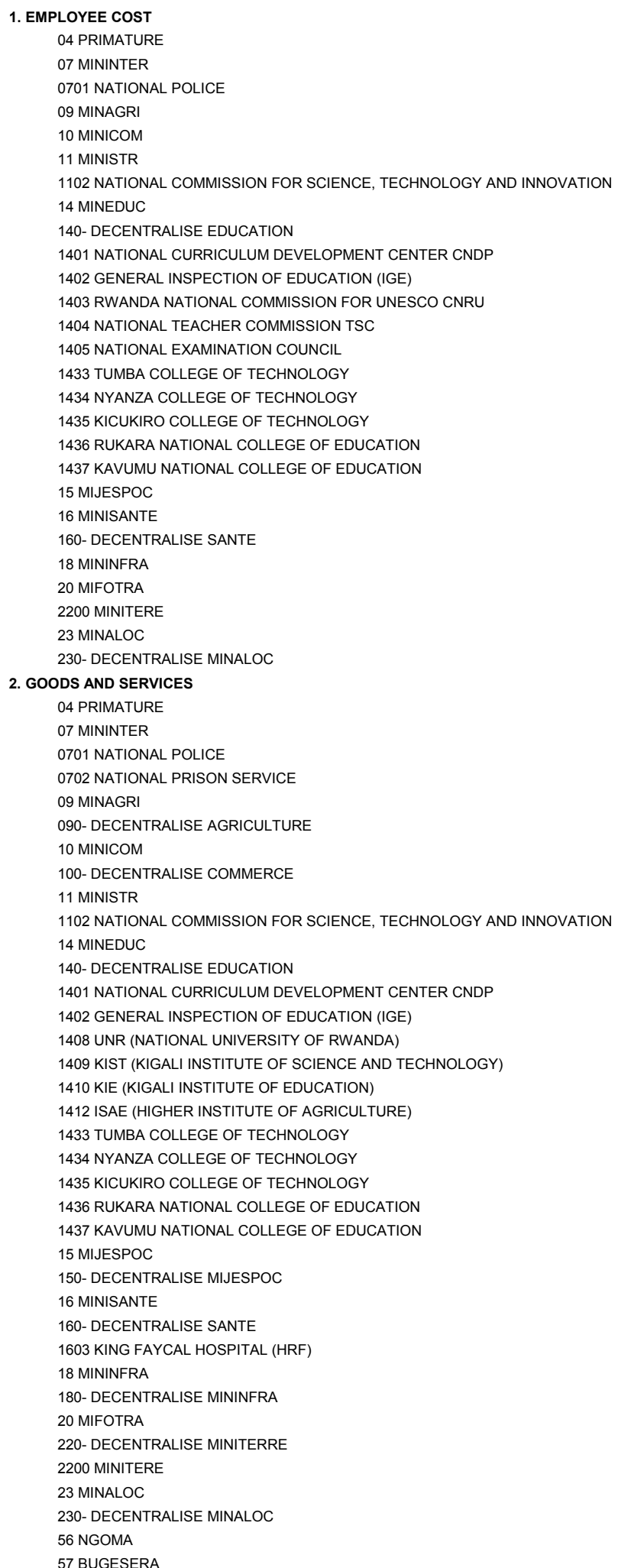

45526.23

105.34

132.44

6801.93

165.37

269.98

150.60

63.20

579.47

22559.75

205.16

163.16

52.31

94.39

378.29

222.00

120.00

222.00

218.84

218.84

84.81

637.59

10621.00

63.45

579.50

203.84

253.82

359.15

42913.78

267.84

211.15

3245.33

139.30

384.19

57.50

1201.61

112.00

627.70

50.40

9497.71

136.31

5795.00

77.70

47.04

19.92

88.40

39.84

331.00

330.00

518.00

553.00

452.00

266.70

78.00

3882.75

1801.73

350.00

6543.45

99.90

510.25

1455.30

1179.59

1916.99

439.87

13.02

11.17 
Priority Spending, 2008 (continued)

(In million of Rwanda Francs)

2. GOODS AND SERVICES (continued)

58 GATSIBO

59 KAYONZA

60 KIREHE

61 NYAGATARE

62 RWAMAGANA

63 HUYE

64 NYAMAGABE

65 GISAGARA

66 MUHANGA

67 KAMONYI

68 NYANZA

69 NYARUGURU

70 RUSIZI

71 NYABIHU

72 RUBAVU

73 KARONGI

74 NGORORERO

75 NYAMASHEKE

76 RUTSIRO

77 BURERA

78 GICUMBI

79 MUSANZE

80 RULINDO

81 GAKENKE

82 RUHANGO

83 NYARUGENGE

84 KICUKIRO

85 GASABO

3. TRANSFER AND SUBSIDIES

O4 PRIMATURE

070- DECENTRALISE PRISON

0701 NATIONAL POLICE

0702 NATIONAL PRISON SERVICE

090- DECENTRALISE AGRICULTURE

0901 OFFICE RWANDAIS DE DEVELOPPEMENT DES RESSOURCES ANIMALES ( RARDA )

0902 INSTITUT DES SCIENCES AGRONOMIQUES DU RWANDA (ISAR)

0903 OFFICE RWANDAIS DE DEVELOPPEMENT DE L AGRICULTURE (RADA)

0904 OFFICE RWANDAIS DE DEVELOPPEMENT DE L'HORTICULTURE (RHODA)

10 MINICOM

100- DECENTRALISE COMMERCE

1002 RWANDA BUREAU OF STANDARDS

1003 RWANDA INVESTMENT AND EXPORT PROMOTION AGENCY

11 MINISTR

1101 RWANDA INFORMATION TECHNOLOGY AUTHORITY (RITA)

1103 IRST (INSTITUTE OF SCIENTIFIC AND TECHNOLOGICAL RESEARCH)

14 MINEDUC

140- DECENTRALISE EDUCATION

1403 RWANDA NATIONAL COMMISSION FOR UNESCO CNRU

1404 NATIONAL TEACHER COMMISSION TSC

1405 NATIONAL EXAMINATION COUNCIL

1406 NATIONAL COUNCIL FOR HIGHER EDUCATION (NCHE)

1407 SFAR (STUDENT FINANCING AGENCYOF RWANDA)

1408 UNR (NATIONAL UNIVERSITY OF RWANDA)

1409 KIST (KIGALI INSTITUTE OF SCIENCE AND TECHNOLOGY)

$1410 \mathrm{KIE}$ (KIGALI INSTITUTE OF EDUCATION)

1411 KHI (KIGALI HEALTH INSTITUTE)

1412 ISAE (HIGHER INSTITUTE OF AGRICULTURE)

1413 SFB (SCHOOL OF FINANCE AND BANKING)

1433 TUMBA COLLEGE OF TECHNOLOGY

15 MIJESPOC

1501 NATIONAL COMMISSION FOR THE FIGHT AGAINST GENOCIDE

1503 RWANDA NATIONAL MUSEUM

1504 PAN AFRICAN ORGANISATION OF YOUTH AGAINST AIDS

6.75

3.10

4.25

4.25

4.25

6.40

6.56

4.25

10.89

5.60

7.50

4.25

14.25

3.10

16.96

8.80

5.41

3.10

3.10

6.56

11.17

5.41

5.05

3.10

3.10

12.56

9.30

3.10

99744.20

17.31

1318.76

70.00

2116.02

955.50

905.21

1693.72

937.32

477.99

1044.42

168.00

1062.24

2142.00

10.00

2497.90

1136.19

934.57

18436.39

96.01

253.61

15.27

199.50

13310.06

1749.49

960.08

594.96

476.75

464.91

354.62

40.00

4.70

322.58

594.11

24.40 
Priority Spending, 2008 (continued)

(In million of Rwanda Francs)

3. TRANSFER AND SUBSIDIES (continued)

2008

16 MINISANTE

160- DECENTRALISE SANTE

1601 CENTRAL UNIVERSITY HOSPITAL OF KIGALI (CHUK)

5129.67

12200.00

790.78

1602 CENTRAL UNIVERSITY HOSPITAL OF BUTARE (CHUB)

649.55

1603 KING FAYCAL HOSPITAL (HRF)

1737.37

1604 NEURO PSYCHIATRIC HOSPITAL OF NDERA (HNN)

330.14

1605 PSYCHOSOCIAL CONSULTATION SERVICE (SCPS)

125.58

1606 RESEARCH CENTER FOR AIDS, MALARIA AND TUBERCULOSIS TREATMENT (TRAC)

371.52

1607 NATIONAL REFERAL LABORATORY(LNR)

227.92

1611 NATIONAL BLOOD TRANSFUSION PROGRAMME (PNTS)

203.72

1612 NATIONAL COMMISSION FOR THE FIGHT AGAINST AIDS (CNLS)

278.63

1613 RWANDA PHARMACEUTICAL LABORATORY (LABOPHAR)

182.70

18 MININFRA

180- DECENTRALISE MININFRA

13813.50

20 MIFOTRA

3500.00

2001 RWANDA INSTITUTE OF ADMINISTRATION AND MANAGEMENT (RIAM)

95.71

70.00

2009 CIVIL SERVICE COMMISSION

80.00

2012 PROFESSIONAL TRAINING CENTER OF KAVUMU

97.00

2200 MINITERE

244.91

2217 NATIONAL LAND OFFICE

632.99

2218 NATIONAL FOREST OFFICE

415.76

2219 NATIONAL MINING AND GEOLOGY OFFICE

448.88

2232 NATIONAL WATER AGENCY

256.28

23 MINALOC

898.16

230- DECENTRALISE MINALOC

1015.52

2302 POLITICAL CONSULTATIVE FORUM

563.32

7.1 DEVELOPMENT BUDGET

79289.67

04 PRIMATURE

07 MININTER

100.00

09 MINAGRI

1212.00

10 MINICOM

5635.09

11 MINISTR

1834.00

12 MINECOFIN

9848.50

14 MINEDUC

1570.00

15 MIJESPOC

14325.00

16 MINISANTE

370.00

18 MININFRA

1267.28

20 MIFOTRA

21622.00

496.30

22 MINITERE

11617.70

23 MINALOC

9391.80

2800.00

2800.00

12 GAZ METHANE

4816.29

4816.29

2301 ELECTORAL COMMISSION 


\section{Table 3. Reporting Requirements for Surveillance}

\begin{tabular}{|c|c|c|c|}
\hline & $\begin{array}{c}\text { Frequency } \\
\text { of } \\
\text { Data }^{6}\end{array}$ & $\begin{array}{l}\text { Frequency } \\
\text { of } \\
\text { Reporting }^{6}\end{array}$ & $\begin{array}{l}\text { Frequency } \\
\text { of } \\
\text { publication }^{6}\end{array}$ \\
\hline Exchange Rates & $\mathrm{D}$ & $\mathrm{W}$ & M \\
\hline International Reserve Assets and Reserve Liabilities of the Monetary Authorities ${ }^{1}$ & W & W & M \\
\hline Reserve/Base Money & W & W & M \\
\hline Broad Money & M & M & M \\
\hline Central Bank Balance Sheet & W & W & M \\
\hline Consolidated Balance Sheet of the Banking System & M & M & M \\
\hline Interest Rates ${ }^{2}$ & M & M & M \\
\hline Consumer Price Index & M & M & M \\
\hline Revenue, Expenditure, Balance and Composition of Financing ${ }^{3}-$ General Government $^{4}$ & M & M & M \\
\hline Revenue, Expenditure, Balance and Composition of Financing ${ }^{3}-$ Central Government & M & M & M \\
\hline Stocks of Central Government and Central Government-Guaranteed Debt ${ }^{5}$ & A & A & A \\
\hline External Current Account Balance & A & SA & A \\
\hline Exports and Imports of Goods and Services & A & A & A \\
\hline GDP/GNP & A & SA & A \\
\hline Gross External Debt & & & \\
\hline
\end{tabular}

${ }^{1}$ Includes reserve assets pledged or otherwise encumbered as well as net derivative positions.

${ }^{2}$ Both market-based and officially-determined, including discount rates, money market rates, rates on treasury bills, notes and bonds.

${ }^{3}$ Foreign, domestic bank, and domestic nonbank financing.

${ }^{4}$ The general government consists of the central government (budgetary funds, extra budgetary funds, and social security funds) and state and local governments.

${ }^{5}$ Including currency and maturity composition.

${ }^{6}$ Daily (D); Weekly (W); Monthly (M); Quarterly (Q); Annually (A); Semi-annually (SA); Irregular (I); Not Available 
Appendix II—Rwanda: Millennium Development Goals

\begin{tabular}{|c|c|c|c|c|c|c|c|c|}
\hline & 1990 & 1995 & 2000 & 2002 & 2003 & 2004 & 2005 & $\begin{array}{l}\text { Likelihood of reaching } \\
\text { the target by } 2015^{\star *}\end{array}$ \\
\hline \multicolumn{9}{|l|}{ Goal 1: Eradicate extreme poverty and hunger } \\
\hline Percentage share of income or consumption held by poorest $20 \%$ & .. &.. & .. &.. &.. &.. & .. & \\
\hline Population below $\$ 1$ a day (\%) & .. &.. & 51.7 & .. &.. & 60 & & Challenging \\
\hline Population below minimum level of dietary energy consumption (\%) & .. & .. & .. & 37 & 37 &.. &.. & \\
\hline Poverty gap ratio at $\$ 1$ a day (incidence $x$ depth of poverty) & .. & .. & 20 & .. & .. &.. & .. & \\
\hline Poverty headcount, national (\% of population) & .. & .. & 60.3 & .. & .. &.. & 56.9 & \\
\hline Prevalence of underweight in children (under five years of age) & .. & .. & 24.3 & .. & .. & .. & .. & Achievable \\
\hline \multicolumn{9}{|l|}{ Goal 2: Achieve universal primary education } \\
\hline Net primary enrollment ratio (\% of relevant age group) & 67.4 &.. & 84 & 86.7 & 86.7 & .. & .. & Likely \\
\hline Primary completion rate, total ( $\%$ of relevant age group) & 44 & .. & 22.4 & 37 & 37.3 & 37.4 & & Achievable \\
\hline Proportion of pupils starting grade 1 who reach grade 5 & 59.9 & .. & 40 & .. & .. & .. &.. & \\
\hline Youth literacy rate (\% ages $15-24)$ & 72.7 & 78.6 & 83.4 & 84.9 & & & .. & \\
\hline Goal 3: Promote gender equality and empower women & & & & & & & & Likely \\
\hline Proportion of seats held by women in national parliament (\%) & 17 & .. & 17 & 26 & 26 & 49 & 49 & \\
\hline Ratio of girls to boys in primary and secondary education (\%) & 96.4 & .. & 96 & 94.8 & 98.7 & 100.1 & 100.1 & Achievable \\
\hline Ratio of young literate females to males (\% ages $15-24)$ & 86.4 & 91.8 & 95.8 & 96.9 & & .. & 97.9 & Likely \\
\hline Share of women employed in the nonagricultural sector $(\%)$ & 16.7 & .. & .. & .. & .. &.. & .. & \\
\hline \multicolumn{9}{|l|}{ Goal 4: Reduce child mortality } \\
\hline Immunization, measles ( $\%$ of children ages $12-23$ months) & 83 & 84 & 74 & 69 & 90 & 84 & 84 & Already Achieved \\
\hline Infant mortality rate (per 1,000 live births) & 103 & 124 & 118 & .. & 118 & 118 & 118 & Achievable \\
\hline Under 5 mortality rate (per 1,000$)$ & 173 & 209 & 203 & .. & 203 & 203 & 203 & Achievable \\
\hline \multicolumn{9}{|l|}{ Goal 5: Improve maternal health } \\
\hline Births attended by skilled health staff (\% of total) & .. & .. & 31.3 & .. & .. &.. & .. & Achievable \\
\hline Maternal mortality ratio (modeled estimate, per 100,000 live births) & .. & .. & 1400 & .. & .. &.. & .. & Unlikely \\
\hline Goal 6: Combat HIVIAIDS, malaria, and other diseases & & & & & & &.. & \\
\hline Contraceptive prevalence rate (\% of women ages $15-49)$ & .. & .. & 13.2 & .. & .. & .. & .. & Challenging \\
\hline Incidence of tuberculosis (per 100,000 people) & 129.7 & 234.6 & 324.1 & 357.3 & 373.8 & 373.8 & 370.9 & \\
\hline Number of children orphaned by HIVIAIDS & .. & .. & 160000 & .. & 160000 & 160000 & 210000 & \\
\hline Prevalence of HIV, total (\% of population aged $15-49$ ) & .. & .. & & .. & 5.1 & & 3 & \\
\hline Tuberculosis cases detected under DOTS $(\%)$ & .. & 35.5 & 34.2 & 31.1 & 27.5 & 27.5 & 29.4 & Already Achieved \\
\hline \multicolumn{9}{|l|}{ Goal 7: Ensure environmental sustainability } \\
\hline Access to an improved water source (\% of population) & 58 & .. & .. & 73 & 73 & .. & 74 & Achievable \\
\hline Access to improved sanitation ( $\%$ of population) & 37 & .. & .. & 41 & & .. & 42 & \\
\hline Access to secure tenure (\% of population) & .. & .. & .. & .. & .. &.. & .. & \\
\hline $\mathrm{CO} 2$ emissions (metric tons per capita) & 0.1 & 0.1 & 0.1 & .. & .. &.. &.. & \\
\hline Forest area ( $\%$ of total land area) & 18.5 & .. & 12.4 & .. & .. & .. & .. & Unlikely \\
\hline GDP per unit of energy use (2000 PPP \$ per kg oil equivalent) & .. & .. & .. & .. & .. & .. & .. & \\
\hline Nationally protected areas (\% of total land area) & .. & .. & .. & .. & 6.2 & 6.2 & 6.2 & \\
\hline \multicolumn{9}{|l|}{ Goal 8: Develop a global partnership for development } \\
\hline Aid per capita (current US\$) & 41.9 & 123.3 & 41.8 & 43.5 & 39.5 & 39.5 & 52.6 & NA \\
\hline Debt service (\% of exports) & .. &.. & .. & .. & 32 & 29.8 & 10 & \\
\hline Fixed line and mobile phone subscribers (per 1,000 people) & 1.7 & 1.3 & 7.3 & 16.4 & 16.4 & .. & 18.2 & \\
\hline Internet users (per 1,000 people) & .. & .. & 0.6 & 3.1 & 3.5 & 4.3 & 4.3 & \\
\hline Personal computers (per 1,000 people) & .. & .. & .. & .. & .. &.. & .. & \\
\hline Unemployment, youth female (\% of female labor force ages $15-24$ ) & .. & .. &.. &.. & .. &.. &.. & \\
\hline Unemployment, youth male (\% of male labor force ages $15-24$ ) & .. & .. &.. & .. & .. &.. &.. & \\
\hline Unemployment, youth total (\% of total labor force ages $15-24$ ) & .. & .. & .. & .. & .. &.. &.. & \\
\hline \multicolumn{9}{|l|}{ Other } \\
\hline Fertility rate, total (births per woman) & 7.1 & .. & 5.9 & .. & 5.6 & 5.5 & 5.5 & \\
\hline GNI per capita, Atlas method (current US\$) & 370 & 220 & 250 & 230 & 200 & 210 & 230 & \\
\hline GNI, Atlas method (current US\$) (billions) & 2.5 & 1.3 & 2.0 & 1.9 & 1.8 & 1.9 & 2.1 & \\
\hline Gross capital formation (\% of GDP) & 14.6 & 13.4 & 17.5 & 19.0 & 18.4 & 20.8 & 21 & \\
\hline Life expectancy at birth, total (years) & 40.2 & .. & 40.9 & 39.8 & 43.7 & 43.9 & 43.9 & \\
\hline Literacy rate, adult total (\% of people ages 15 and above) & 53.3 & 60.2 & 66.8 & 69.2 & & 69.4 & 64.9 & \\
\hline Population, total (millions) & 6.9 & 5.7 & 8.0 & 8.2 & 8.8 & 8.9 & 9 & \\
\hline Trade ( $\%$ of GDP) & 19.7 & 31.0 & 32.6 & 33.1 & 36.2 & 36.2 & 41.5 & \\
\hline
\end{tabular}

Source: World Development Indicators Database, April 2006.

Data in italics are estimates.

${ }^{* *}$ World Bank Estimates 


\section{INTERNATIONAL MONETARY FUND AND \\ INTERNATIONAL DEVELOPMENT ASSOCIATION}

RWANDA

Joint IMF/World Bank Debt Sustainability Analysis

Prepared by the Staffs of the International Monetary Fund and the International Development Association

Approved by Hugh Bredenkamp and Mark Plant (IMF)

and Obiageli K. Ezekwesili (IDA)

February 14, 2008

This debt sustainability analysis (DSA) assesses the sustainability of Rwanda's external and domestic public debt. It was conducted jointly by the staffs of the IMF and the World Bank using the Bank-Fund framework for debt sustainability analysis for low-income countries. ${ }^{1}$ On the basis of this DSA, the staffs conclude that Rwanda continues to be at high risk of debt distress. $^{2}$

\section{BACKGROUND}

The last joint DSA concluded that Rwanda is at high risk of debt distress. ${ }^{3}$ Rwanda reached the HIPC completion point in April 2005 and qualified for the MDRI in January 2006, which substantially improved its debt indicators. ${ }^{4}$ Nonetheless, given its small

\footnotetext{
${ }^{1}$ The external debt data and domestic debt data underlying this DSA are to be confirmed by the Rwandan authorities.

${ }^{2}$ A country is considered at high risk of debt distress if the baseline scenario indicates a protracted breach of debt or debt-service thresholds, but the country does currently not face any payment difficulties.

${ }^{3}$ The last DSA was undertaken in May 2006 (Appendix VI in IMF Country Report No. 06/245).

${ }^{4}$ The implementation of debt relief under the enhanced HIPC initiative is at an advanced stage. In addition to the IMF, IDA, and AfDB, completion point and topping up assistance have been provided by BADEA and the OPEC Fund. IFAD, the Kuwait Fund, the Saudi Fund and the EU have already provided completion point assistance. Bilateral agreements have been signed with all Paris creditors. Regarding non-Paris Club creditors, China has canceled all outstanding loans, while Saudi Arabia and Kuwait noted the possibility of future debt relief. Debt owned to Libya and the Abu Dhabi Fund continues to be in technical arrears.
} 
export base and vulnerability to shocks, the DSA concluded that continued high levels of grants were needed to maintain the NPV of external debt-to-exports ratio at sustainable levels.

\section{Total public sector debt declined in 2006 due to implementation of the MDRI.}

External debt outstanding amounted to 16.7 percent of GDP at end-2006, down from 70.7 percent of GDP at end-2005. Domestic debt, ${ }^{5}$ including pre-genocide debt, amounted to 12 percent of GDP at end-2006. ${ }^{6}$ In terms of the composition by creditor, about half of public debt at end-2006 was with multilaterals and 10 percent with official bilaterals, the remainder being domestic (Text Figure 1).

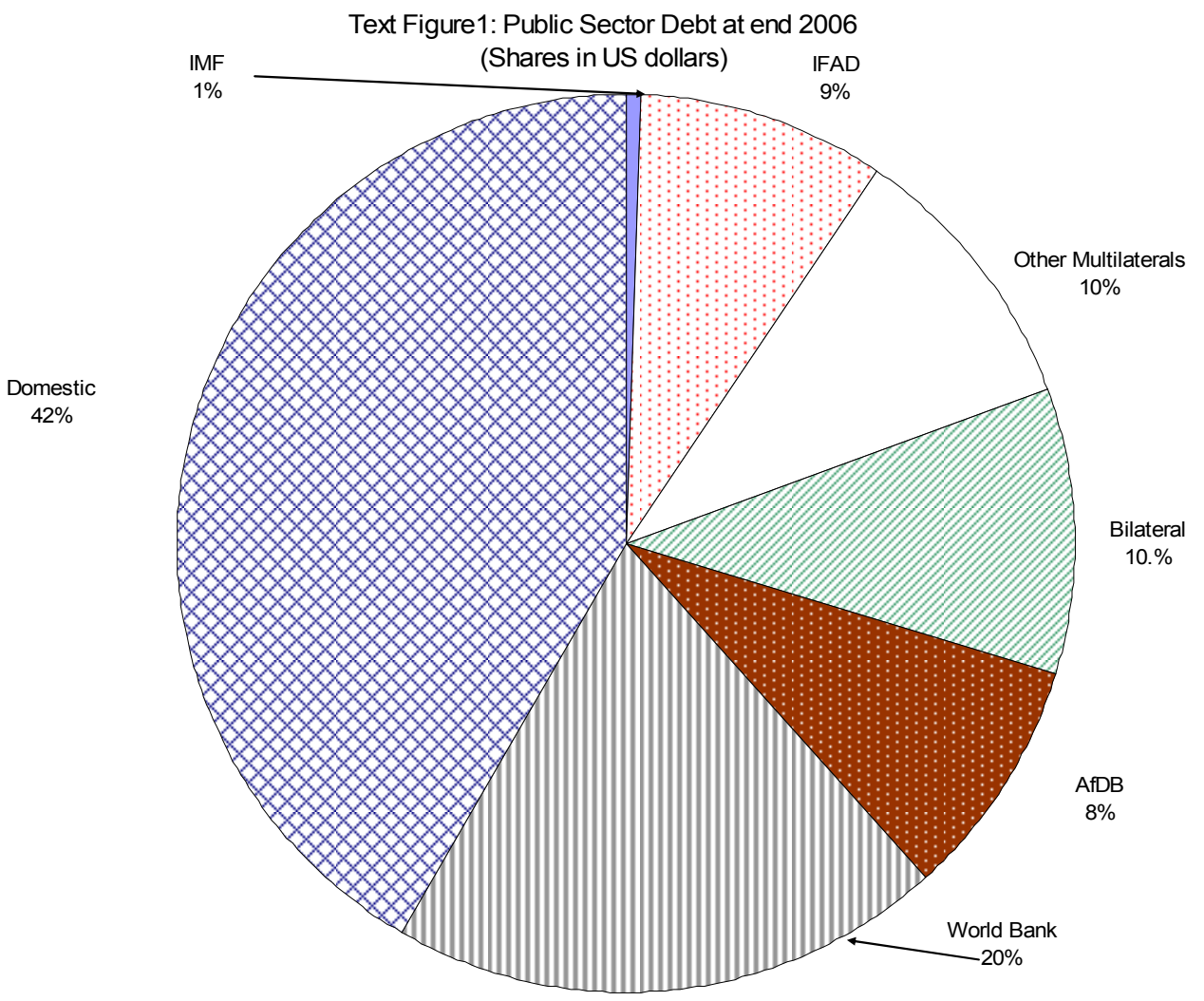

\footnotetext{
${ }^{5}$ The last DSA did not include domestic debt because data on pre-genocide debt were not available.

${ }^{6}$ Information on the stock of domestic debt at end-2005 is pending from the authorities. There is no information available on local government or public enterprise debt.
} 


\section{Rwanda's external debt situation in $\mathbf{2 0 0 6}$ was more favorable than envisaged in the last DSA, due to stronger export performance:}

- A substantial over performance in exports of tea and coffee as well as tourism services more than offset slightly higher borrowing in $2006^{7}$ (Text Table 1). As a result, the actual NPV of external debt-to-exports ratio was 55 percent at end-2006, compared with a ratio of 66 percent projected in the last DSA. ${ }^{8}$

Text Table 1. Projected Versus Actual NPV of External Debt-to-Exports Ratio at End-2006 (In percent)

\begin{tabular}{lc}
\hline NPV of debt-to -exports in 2006 as projected in previous DSA & 65.6 \\
\hline Actual NPV of debt-to exports in 2006 & 54.8 \\
Factors contributing to changes: & \\
$\quad$ New borrowing & $(1.2)$ \\
Exports (higher than anticipated) & 9.4 \\
$\quad$ Residual 1/ & 2.5 \\
\hline Source: Staff estimates. & \\
1/ Includes exchange rate changes. &
\end{tabular}

4. Despite these favorable developments, the revised DSA concludes that Rwanda remains at high risk of debt distress because of its small export base. This DSA includes higher spending deemed critical for advancing more rapidly toward the MDGs and addressing Rwanda's severe infrastructure gap. While most of the spending would be covered by higher revenue and grants, an increase in external loan financing would also be required. Given these assumptions, trends in debt indicators remain similar to those estimated in the previous DSA.

\footnotetext{
${ }^{7}$ Actual borrowing at US\$72 million in 2006 was higher than projected by US\$8 million due to higher IDA financing.

${ }^{8}$ Including debt relief provided at the decision point, topping up under the HIPC Initiative and MDRI debt relief.
} 


\section{Medium-Term Macroeconomic Framework}

\section{The macroeconomic framework is more favorable than the one presented in the} last DSA (Box 1). ${ }^{9}$ The main changes are:

- $\quad$ Public spending is higher by about 4 percent of GDP on average per year, reflecting increased investment spending in the social sectors.

- $\quad$ The revenue ratio is higher because of a higher base in 2007 (revenue in 2007 is projected at 15.5 percent of GDP compared with 14.8 percent of GDP projected in the last DSA) and the expectation of a stronger effort to finance higher spending.

- $\quad$ The proportion of loans in total financing increases from about 10 percent in 2008 to an annual average of about 32 percent in 2009-12, and returns to 33 percent thereafter. In 2008 World Bank budget support is in the form of grants and is assumed as loans from 2009-2012. External grant financing from 2009-2012, excluding World Bank budget support, is in line with the authorities' estimates of committed grants as contained in the Economic Development and Poverty Reduction Strategy (EDPRS). The remaining financing gap from 2008-2012 is assumed to be financed with loans at 56 percent concessionality.

- $\quad$ Export growth has been revised upwards by 1 percentage point to an annual average of about 10 percent. The commodity export growth projection is in line with that of the authorities from 2008-2012. Exports of services are also projected to grow at an annual average rate of about 10 percent.

\footnotetext{
9 The authorities rebased the GDP from 2001, improving the methodology, while using updated information contained in the 2005 household survey. The underlying macroeconomic framework is based on the revised GDP estimates. However the old GDP series is used in this section to compare the assumptions of the current and previous DSA.
} 


\section{Box 1. Macroeconomic Assumptions}

The macroeconomic assumptions are as follows:

Real GDP growth is projected to stabilize at about 6 percent for the projection period as growth-enhancing sectoral strategies take effect and investment in human capital (health and education sectors) starts to pay off. In the short term, growth is expected to be generated by boosting productivity in the agriculture and export sectors (mostly tea, coffee and mining) through improving water management, controlling soil erosion, intensifying the use of fertilizer, integrating livestock development into crop farming, and enhancing extension services. Over the long term, measures to facilitate trade and reduce transaction costs as well as investments in infrastructure and human capital are expected to boost growth in the services and manufacturing sectors.

Per capita GDP growth is projected to remain at about 3.5 percent from 2008-2027. This assumes a reduction in the rate of population growth over time (from the current level of 2.7 percent to 2.1 percent) as government policies to promote family planning, increase the distribution of contraceptives and raise the education level begin to take effect

Exports of goods and services are assumed to grow at a nominal rate of about 12 percent until 2013 in U.S. dollar terms as the export promotion strategy takes effect and stabilize thereafter at about 9 percent. Export growth reflects interventions aimed at increasing yield and value added in the coffee and tea industry through increased utilization of fertilizers, improved harvesting methods and better seed quality. Services exports are likely to remain buoyant on account of improved marketing efforts and increased hotel room capacity.

Imports of goods and services are projected to increase by 6 percent on average over the period 2007-27, mostly due to growing demand for capital good imports from the private sector, which is partly offset by substantially lower transportation costs because of better infrastructure links both internally and with neighboring countries. 
Text Table 2. Rwanda: Medium-Term Framework, (period average, 2007-2012, in percent of GDP)

\begin{tabular}{lrrr}
\hline & $\begin{array}{r}\text { Current DSA } \\
\text { New GDP }\end{array}$ & $\begin{array}{r}\text { Current DSA } \\
\text { Old GDP }\end{array}$ & $\begin{array}{r}\text { Sixth PRGF } \\
\text { Review }\end{array}$ \\
\hline Economic growth and inflation & & & \\
Real GDP (percentage change) & 5.7 & 5.4 & 4.9 \\
Real GDP (per capita) & 3.6 & 3.3 & 2.2 \\
Average inflation (in percent) & 6.1 & 6.1 & 5.0 \\
Fiscal sector & & & \\
Government revenue & & & \\
$\quad$ Excluding grants & 13.8 & 16.0 & 14.8 \\
Government expenditure and net lending & 27.1 & 31.2 & 27.1 \\
$\quad$ Current expenditure & 16.7 & 19.2 & 17.5 \\
$\quad$ Capital expenditure & 10.2 & 11.7 & 9.0 \\
Primary budget balance & -4.4 & -5.1 & -2.0 \\
Balance of payments & & & \\
Exports of goods and services & 9.8 & 11.3 & 12.6 \\
Imports of goods and services & 30.1 & 34.9 & 29.2 \\
External current account balance & & & \\
$\quad$ Excluding official transfers & & -21.2 & -16.7 \\
Including official transfers & -18.0 & -11.2 & -7.9 \\
NPV of debt to export ratio & -9.9 & 85.7 & 116.1 \\
Gross official reserves (in months of imports) & 85.7 & 5.1 & 4.6 \\
\hline
\end{tabular}

Sources: Rwandan authorities; and staff estimates and projections.

${ }^{1}$ GDP series was rebased using new data derived from the 2005 household survey. The rebased series is more comprehensive in coverage with improved methodology broadly in line with international standards.

\section{External Debt Sustainability Analysis}

\section{A. Baseline}

\section{One critical debt burden indicator would exceed its policy-dependent threshold}

in the baseline (Figure 1). Rwanda's NPV of debt-to-exports ratio is projected to rise above 150 percent by 2018 and decline thereafter to be slightly below the threshold by 2027 . The NPV of external debt-to-GDP ratio and the NPV of debt-to-revenue ratios remain well below their thresholds throughout the forecast period, while debt service payments continue to be manageable at below 10 percent of exports. Despite about one third of financing stemming from highly concessional loans from 2012 onwards, the NPV of external debt-to-exports 
ratio would breach the policy-dependent threshold of 150 percent by 2018 , peaking at about 154 percent in 2020 , and declining to 143 percent in $2027 .^{10}$

Text Table 3: Policy-Based External Debt Burden Indicators

\begin{tabular}{lrrr}
\hline & Thresholds 1/ & \multicolumn{2}{c}{ Rwanda's ratios } \\
\cline { 3 - 4 } & & 2007 & $2008-272 /$ \\
\hline NPV of debt in percent of: & 150 & 62 & 132 \\
$\quad$ Exports & 40 & 63 & 15 \\
$\quad$ GDP & 250 & 1 & 47 \\
$\quad$ Revenue & 20 & 1 & 3 \\
Debt service in percent of & 30 & \\
$\quad$ Exports & & \\
$\quad$ Revenue & & \\
1/ Policy indicative thresholds as used in the joint IMF-World Bank LIC DSA \\
framework for medium policy performance. The quality of policies and institutions are \\
measured by the World Bank's CPIA index. \\
2/ Simple average.
\end{tabular}

7. Including additional borrowing to finance the planned energy and agriculture projects contracted at less than 50 percent concessionality does not significantly alter the baseline estimates. ${ }^{11}$ The NPV of debt to export threshold would be breached in 2013 and peak at 177 percent in 2018 .

\section{B. Alternative Scenarios and Stress Tests}

\section{Rwanda's debt dynamics would deteriorate sharply if external financing were} delivered on less favorable terms. A 2 percentage point increase in interest rates on all new borrowing (reflecting borrowing at less concessional terms) starting in 2007 would substantially increase Rwanda's NPV of debt-to-exports ratio, which would breach the threshold by 2012 and remain above 225 percent from 2017 onward. ${ }^{12}$ This indicates that Rwanda should rely to a large extent on grants to finance its development efforts.

\footnotetext{
${ }^{10}$ The World Bank’s CPIA classifies Rwanda as a medium policy performer.

${ }^{11}$ Concessionality of these loans is assumed at about 40 percent (20 year maturity, 5 year grace period and interest rate of 1.75 percent).

12 The 2 percent increase in interest rates would be equivalent to lowering the grant element to under 35 percent from 2009 onward (which is below the grant element of 50 percent required under the Rwanda's PRGF).
} 
9. Shocks to the small export base would substantially worsen Rwanda's NPV of debt-to-exports ratio. ${ }^{13}$ If exports were to grow at the historical average less one standard deviation in 2008 (equivalent to a 11.6 percent reduction in exports in 2008 relative to the baseline). Rwanda's NPV of debt-to-exports ratio would exceed 150 percent from 2012 onward, peaking at over 202 percent in 2019. ${ }^{14}$ This scenario highlights the importance of effective export promotion to set Rwanda on a sustainable debt path.

10. Stress tests based on historical averages also indicate that Rwanda could experience an increased risk of debt distress. For instance, if key macroeconomic variables remained at historical values, the NPV of external debt-to-exports ratio would follow a persistent upward path reaching 166 percent in 2027.

11. Rwanda's risk of debt distress could be lower if the authorities are able to substantially raise the level of grant financing. Even with the inclusion of borrowing of about US\$180m to finance infrastructure projects (authorities' scenario, Text Figure 2) ${ }^{15}$, higher grant funding, in line with the authorities medium-term expectations, would improve Rwanda's debt dynamics. The authorities project lower debt financing than under the baseline scenario over the medium term, 2009-2012. In particular, they assume that (i) World Bank budget support funding will be in the form of grants, and (ii) 67 percent of the residual financing gap (after taking into account grants already committed) is funded through grants and the remainder with concessional loans with a grant element of 56 percent. Under this scenario the proportion of grants in total external financing would stand at about 90 percent from 2009-2012, highlighting the strong reliance on grant financing for budget support and development purposes and maintaining debt sustainability. From 2013 the proportion of grants in total financing is in line with the baseline (at 67 percent). As a result, the NPV of debt to export ratio, the only threshold breached in the baseline scenario, would remain below 150 percent throughout the forecast period, peaking at 124 percent in 2024 and declining thereafter.

\footnotetext{
14 The "historical" scenario is calculated on the basis of performance during 1997 to 2006.

${ }^{15}$ The marginal growth impact of these projects is unknown and is assumed to be zero.
} 


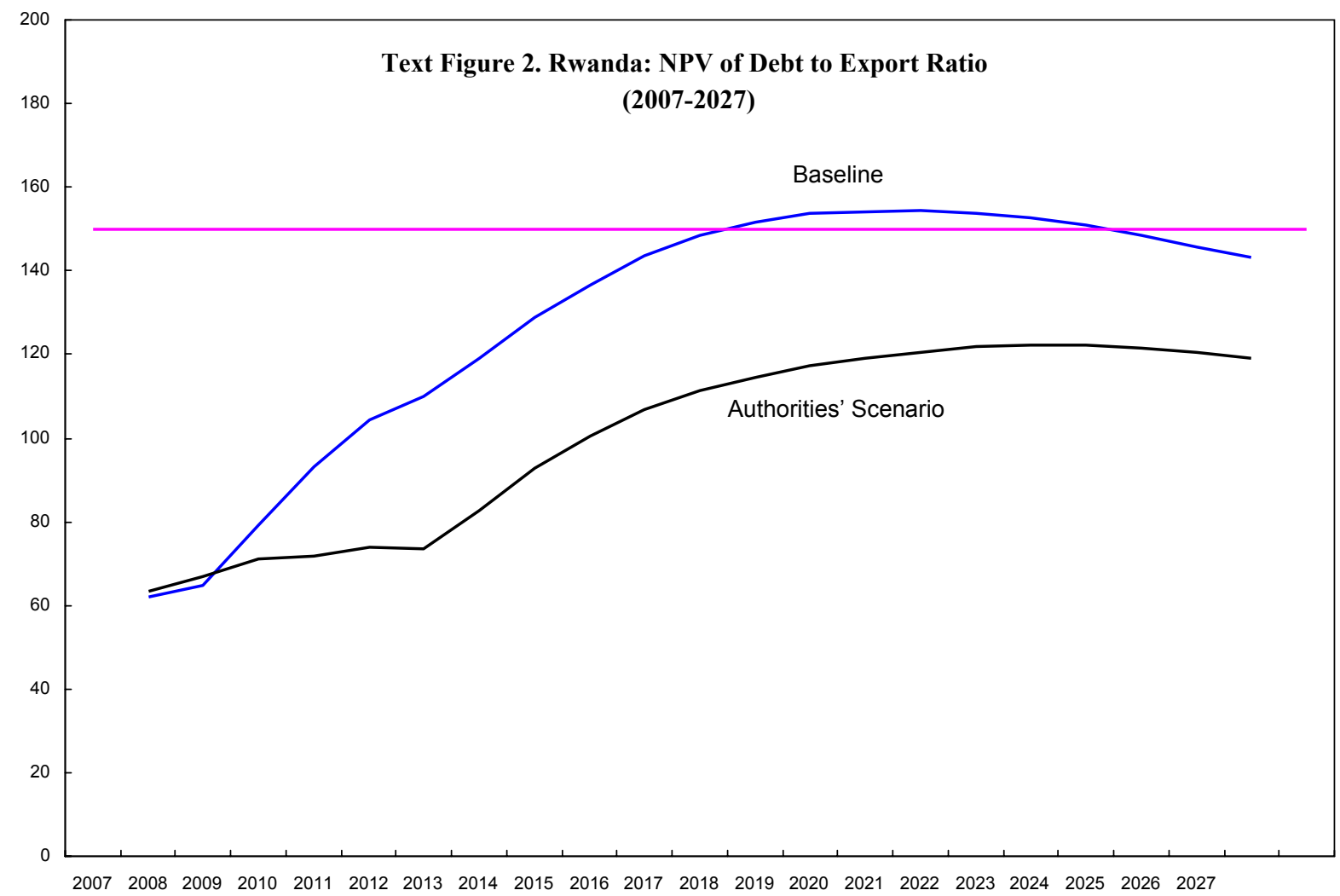

III. Public Debt Sustainability Analysis

\section{A. Baseline}

\section{Rwanda's public debt burden (including domestic debt) is expected to stabilize} over the projection period. ${ }^{16}$ With moderate domestic financing over the long term, the NPV of domestic debt is expected to decline with the repayment of the pre genocide debt, stabilizing at about 5.8 percent of GDP from 2012 onward. This trend is partly offsetting the increase in external debt, so that the NPV of total public debt-to-GDP ratio would increase from 15 percent in 2007 and stabilize at about 20 percent in the long term. The debt serviceto-revenue ratio would remain below 5 percent (Table 3).

\footnotetext{
${ }^{16}$ The DSA excludes (1) contingent liabilities of the pension fund; and (2) possible take off government guarantees for the public power utility Electrogaz, which are not yet quantifiable because projects in the sector are still at an early stage.
} 


\section{B. Alternative Scenarios and Stress Tests}

\section{Lower GDP growth would result in much less favorable debt dynamics. Both} growth-related stress tests (assuming growth at the historical average less one standard deviation in 2008-09 and permanently lower growth during 2009-27) imply a substantial worsening in all debt indicators (though all indicators stay below debt burden thresholds). This underscores the importance of selecting and investing only in infrastructure projects with a high rate of return and undertaking structural reforms to set the stage for robust private sector growth.

14. Debt indicators would worsen under the no-reform scenario, where the revenue GDP ratio is unchanged from 2007 onward. The NPV of debt-to-GDP ratio would climb to 80 percent by 2027 . The NPV of debt to revenue ratio would follow an explosive path reaching 312 percent in 2027. This scenario highlights the importance of improving the revenue effort in order to reduce long-term aid dependence and attain debt sustainability.

\section{CONCLUSION}

15. Rwanda is at high risk of debt distress. Despite reduced risk of near-term debt distress, owing to recent debt relief and favorable debt developments in the last year, exogenous shocks to exports or imprudent borrowing on nonconcessional terms could cause a rapid deterioration in the medium-term outlook. The alternative scenarios and stress test indicate that debt indicators are highly sensitive to less concessional financing and lower growth, particularly in exports.

\section{The DSA suggests that investment and structural reforms should focus on} enhancing private-sector led growth and protecting Rwanda against shocks. Reducing the cost of doing business, financial sector reform and infrastructure investments will be key. With support from both the EU and the World Bank, investments in road construction should help reduce the costs of transport as should regional projects through the Nile Basin Initiative, and a regional Bank project on transport. Rwanda is also consulting with donors on an energy sector strategy to systematically address its energy constraints in a sustainable manner. In addition, government is elaborating a strategy to develop vocational education and training, and ensure that the education system is producing the types of graduates that are most needed for employment and growth. These efforts, together with measures to promote exports, should not only raise overall growth, but also help improve the business and investment climate, and facilitate a strengthening and diversification of the export base. At the same time, the authorities are committed to reforms to improve expenditure and debt management and raise the revenue-to-GDP ratio for an eventual exit from donor flows. 
Figure 1. Rwanda: Indicators of Public and Publicly Guaranteed External Debt Under Alternative Scenarios, 2007-2027
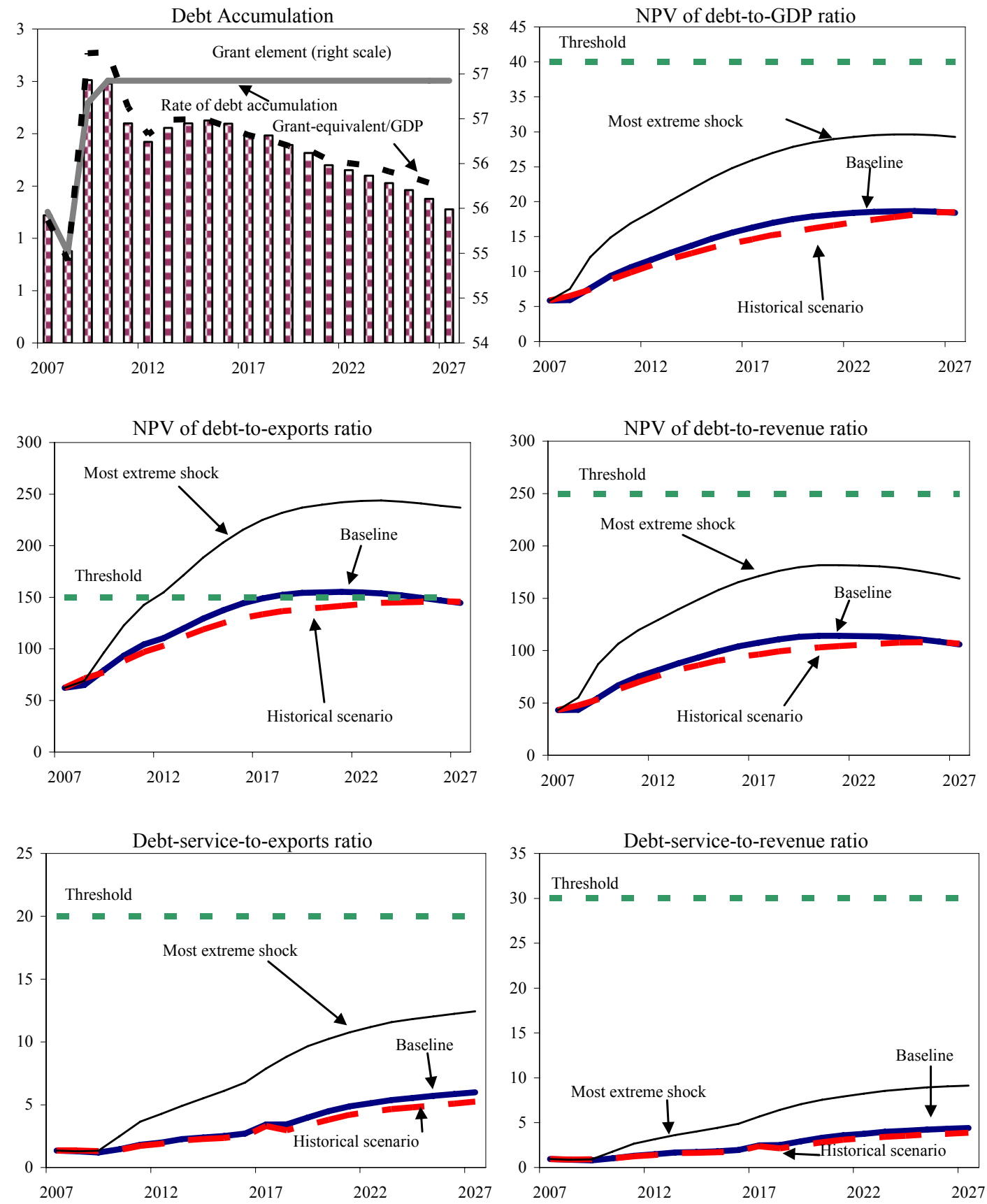

Source: Staff projections and simulations. 
Table 1. Rwanda: External Debt Sustainability Framework, Baseline Scenario, 2007-2027 1/

(In percent of GDP, unless otherwise indicated)

\begin{tabular}{|c|c|c|c|c|c|c|c|c|c|c|c|c|c|c|c|c|}
\hline & \multicolumn{2}{|c|}{ Actual } & \multirow{2}{*}{$\begin{array}{l}\text { Historical } \\
\text { Average 6/ }\end{array}$} & \multirow{2}{*}{$\begin{array}{c}\text { Standard } \\
\text { Deviation 6/ }\end{array}$} & \multicolumn{4}{|c|}{ Projections } & & \multirow[b]{2}{*}{2014} & \multirow[b]{2}{*}{2015} & \multirow[b]{2}{*}{2020} & \multirow[b]{2}{*}{2025} & \multirow[b]{2}{*}{2026} & \multirow[b]{2}{*}{2027} \\
\hline & 2005 & 2006 & & & 2007 & 2008 & 2009 & 2010 & $\begin{array}{l}2007-12 \\
\text { Average }\end{array}$ & 2013 & & & & & & \\
\hline External debt (nominal) 1/ & 70.7 & 16.7 & & & 16.4 & 15.8 & 19.0 & 22.5 & & 28.1 & 29.7 & 31.2 & 35.2 & 34.9 & 34.5 & 34.0 \\
\hline Change in external debt & -14.3 & -54.0 & & & -0.2 & -0.6 & 3.3 & 3.5 & & 1.7 & 1.6 & 1.5 & 0.4 & -0.3 & -0.4 & -0.5 \\
\hline Identified net debt-creating flows & -14.6 & -14.0 & & & -2.8 & 1.0 & 3.7 & 2.2 & & 1.3 & 1.6 & 1.4 & 0.6 & 0.0 & -0.2 & 0.2 \\
\hline Non-interest current account deficit & 4.2 & 6.6 & 6.6 & 2.0 & 4.8 & 9.4 & 12.6 & 11.7 & & 8.6 & 8.8 & 8.7 & 7.3 & 4.8 & 4.2 & 4.0 \\
\hline Deficit in balance of goods and services & 18.4 & 17.2 & & & 18.3 & 22.4 & 21.9 & 20.3 & & 17.6 & 17.5 & 17.1 & 14.4 & 10.9 & 10.3 & 10.1 \\
\hline Imports & 27.9 & 27.4 & & & 27.7 & 31.5 & 31.4 & 30.3 & & 28.2 & 28.2 & 27.8 & 25.9 & 23.4 & 22.9 & 22.8 \\
\hline Net current transfers (negative $=$ inflow) & -15.1 & -10.1 & -11.1 & 2.2 & -13.9 & -13.1 & -9.5 & -8.8 & & -9.0 & -8.7 & -8.4 & -7.0 & -6.0 & -6.0 & -5.9 \\
\hline $\mathrm{o} / \mathrm{w}$ official & -13.1 & -8.6 & & & -11.1 & -10.5 & -7.0 & -6.3 & & -6.5 & -6.2 & -6.0 & -4.5 & -3.3 & -3.3 & -3.2 \\
\hline Other current account flows (negative $=$ net inflow) & 1.0 & -0.6 & & & 0.4 & 0.1 & 0.3 & 0.2 & & 0.0 & 0.0 & 0.0 & -0.1 & -0.1 & -0.1 & -0.2 \\
\hline Net FDI $($ negative $=$ inflow) & -4.6 & -8.8 & -4.3 & 2.0 & -6.8 & -7.7 & -8.2 & -8.7 & & -6.1 & -5.9 & -5.9 & -5.0 & -3.2 & -2.8 & -2.2 \\
\hline Endogenous debt dynamics $2 /$ & -14.3 & -11.8 & & & -0.8 & -0.8 & -0.7 & -0.9 & & -1.2 & -1.3 & -1.4 & -1.6 & -1.6 & -1.6 & -1.6 \\
\hline Contribution from nominal interest rate & 0.2 & 0.1 & & & 0.1 & 0.1 & 0.1 & 0.1 & & 0.2 & 0.2 & 0.2 & 0.2 & 0.2 & 0.2 & 0.2 \\
\hline Contribution from real GDP growth & -5.0 & -3.2 & & & -0.9 & -0.9 & -0.8 & -1.0 & & -1.4 & -1.5 & -1.6 & -1.8 & -1.9 & -1.9 & -1.8 \\
\hline Contribution from price and exchange rate changes & -9.5 & -8.6 & & & $\ldots$ & $\ldots$ & $\ldots$ & $\ldots$ & & $\ldots$ & $\ldots$ & $\ldots$ & $\ldots$ & $\ldots$ & $\ldots$ & $\ldots$ \\
\hline Residual (3-4) 3/ & 0.3 & -40.0 & & & 2.5 & -1.6 & -0.5 & 1.3 & & 0.4 & 0.0 & 0.1 & -0.2 & -0.3 & -0.2 & -0.7 \\
\hline NPV of external debt $4 /$ & $\ldots$ & 5.6 & & & 5.9 & 5.9 & 7.6 & 9.3 & & 12.7 & 13.7 & 14.7 & 17.9 & 18.5 & 18.4 & 18.3 \\
\hline In percent of exports & $\ldots$ & 54.8 & & & 62.1 & 65.0 & 79.3 & 93.3 & & 119.2 & 128.8 & 136.8 & 154.2 & 148.4 & 145.8 & 143.4 \\
\hline NPV of PPG external debt & ... & 5.6 & & & 5.9 & 5.9 & 7.6 & 9.3 & & 12.7 & 13.7 & 14.7 & 17.9 & 18.5 & 18.4 & 18.3 \\
\hline In percent of exports & $\ldots$ & 54.8 & & & 62.1 & 65.0 & 79.3 & 93.3 & & 119.2 & 128.8 & 136.8 & 154.2 & 148.4 & 145.8 & 143.4 \\
\hline In percent of government revenues & ... & 42.2 & & & 43.3 & 43.3 & 55.4 & 67.5 & & 88.4 & 94.4 & 100.2 & 113.7 & 110.0 & 107.8 & 105.2 \\
\hline Debt service-to-exports ratio (in percent) & 6.3 & 2.1 & & & 1.3 & 1.3 & 1.2 & 1.5 & & 2.3 & 2.4 & 2.5 & 4.5 & 5.7 & 5.8 & 6.0 \\
\hline PPG debt service-to-exports ratio (in percent) & 6.3 & 2.1 & & & 1.3 & 1.3 & 1.2 & 1.5 & & 2.3 & 2.4 & 2.5 & 4.5 & 5.7 & 5.8 & 6.0 \\
\hline PPG debt service-to-revenue ratio (in percent) & 4.5 & 1.6 & & & 0.9 & 0.9 & 0.8 & 1.1 & & 1.7 & 1.7 & 1.8 & 3.3 & 4.2 & 4.3 & 4.4 \\
\hline Total gross financing need (billions of U.S. dollars) & 5.6 & -58.0 & & & -61.6 & 70.8 & 191.0 & 144.7 & & 156.3 & 191.4 & 201.5 & 263.5 & 326.0 & 321.4 & 415.4 \\
\hline Non-interest current account deficit that stabilizes debt ratio & 18.5 & 60.6 & & & 5.0 & 10.0 & 9.4 & 8.3 & & 6.9 & 7.2 & 7.2 & 6.8 & 5.1 & 4.5 & 4.5 \\
\hline \multicolumn{17}{|l|}{ Key macroeconomic assumptions } \\
\hline Real GDP growth (in percent) & 7.1 & 5.5 & 10.1 & 7.0 & 6.0 & 6.0 & 5.6 & 5.5 & 5.7 & 5.7 & 5.7 & 5.7 & 5.7 & 5.7 & 5.7 & 5.7 \\
\hline GDP deflator in US dollar terms (change in percent) & 12.6 & 13.9 & -1.1 & 14.7 & 9.2 & 7.3 & 5.1 & 2.1 & 4.6 & 2.0 & 2.0 & 2.0 & 2.0 & 2.0 & 2.0 & 2.0 \\
\hline Effective interest rate (percent) $5 /$ & 0.3 & 0.1 & 0.6 & 0.4 & 0.5 & 0.5 & 0.5 & 0.6 & 0.5 & 0.7 & 0.7 & 0.7 & 0.7 & 0.7 & 0.8 & 0.8 \\
\hline Growth of exports of G\&S (US dollar terms, in percent) & 20.2 & 27.7 & 16.2 & 27.8 & 7.5 & 9.9 & 16.7 & 12.7 & 11.3 & 8.6 & 7.8 & 8.8 & 10.0 & 9.5 & 9.3 & 8.6 \\
\hline Growth of imports of G\&S (US dollar terms, in percent) & 27.1 & 17.9 & 8.7 & 13.0 & 17.2 & 29.3 & 10.7 & 3.9 & 11.6 & 7.6 & 7.5 & 6.5 & 4.5 & 5.8 & 5.6 & 7.2 \\
\hline Grant element of new public sector borrowing (in percent) & $\ldots$ & $\ldots$ & $\ldots$ & $\ldots$ & 55.5 & 55.0 & 56.7 & 56.9 & 56.3 & 56.9 & 56.9 & 56.9 & 56.9 & 56.9 & 56.9 & 56.9 \\
\hline Aid flows (in billions of US dollars) $7 /$ & $\ldots$ & 0.5 & & & 0.5 & 0.6 & 0.7 & 0.6 & & 0.7 & 0.8 & 0.8 & 1.0 & 1.2 & 1.2 & 1.2 \\
\hline Grant-equivalent financing (in percent of GDP) 8/ & $\ldots$ & $\ldots$ & & & 1.2 & 0.8 & 2.8 & 2.8 & & 2.1 & 2.1 & 2.1 & 1.8 & 1.6 & 1.5 & 1.4 \\
\hline Grant-equivalent financing (in percent of external financing) 8 / & $\ldots$ & $\ldots$ & & & 55.7 & 55.4 & 56.8 & 57.0 & & 57.0 & 57.0 & 57.0 & 57.0 & 57.0 & 57.0 & 57.0 \\
\hline \multicolumn{17}{|l|}{ Memorandum items: } \\
\hline Nominal GDP (billions of US dollars) & 2387.2 & 2867.3 & & & 3320.0 & 3776.4 & 4188.5 & 4508.9 & & 5647.1 & 6087.2 & 6561.7 & 9551.2 & 13906.1 & 14991.6 & 16162.0 \\
\hline (NPVt-NPVt-1)/GDPt-1 (in percent) & & & & & 1.2 & 0.9 & 2.5 & 2.5 & 1.8 & 2.0 & 2.1 & 2.1 & 1.8 & 1.4 & 1.4 & 1.3 \\
\hline
\end{tabular}

$1 /$ Includes both public and private sector external debt.

2/ Derived as $[r-g-\rho(1+g)] /(1+g+\rho+g \rho)$ times previous period debt ratio, with $r=$ nominal interest rate; $g=$ real GDP growth rate, and $\rho=$ growth rate of GDP deflator in U.S. dollar terms.

3/ Includes exceptional financing (i.e., changes in arrears and debt relief); changes in gross foreign assets; and valuation adjustments. For projections also includes contribution from price and exchange rate changes.

4/ Assumes that NPV of private sector debt is equivalent to its face value.

5/ Current-year interest payments divided by previous period debt stock.

6/ Historical averages and standard deviations are generally derived over the past 10 years, subject to data availability.

7/ Defined as grants, concessional loans, and debt relief.

8/ Grant-equivalent financing includes grants provided directly to the government and through new borrowing (difference between the face value and the NPV of new debt). 
Table 2. Rwanda: Sensitivity Analyses for Key Indicators of Public and Publicly Guaranteed External Debt, 2007-27

$$
\text { (In percent) }
$$

\begin{tabular}{|c|c|c|c|c|c|c|c|c|c|c|c|c|c|}
\hline & \multicolumn{13}{|c|}{ Projections } \\
\hline & 2007 & 2008 & 2009 & 2010 & 2011 & 2016 & 2017 & 2018 & 2022 & 2023 & 2024 & 2026 & 2027 \\
\hline \multicolumn{14}{|c|}{ NPV of debt-to-GDP ratio } \\
\hline Baseline & 6 & 6 & 8 & 9 & 11 & 16 & 16 & 17 & 18 & 18 & 19 & 18 & 18 \\
\hline \multicolumn{14}{|l|}{ A. Alternative Scenarios } \\
\hline A1. Key variables at their historical averages in 2008-27 1/ & 6 & 6 & 7 & 9 & 10 & 14 & 15 & 15 & 17 & 17 & 18 & 18 & 18 \\
\hline A2. New public sector loans on less favorable terms in 2008-27 2/ & 6 & 6 & 9 & 12 & 14 & 23 & 25 & 26 & 29 & 29 & 30 & 30 & 30 \\
\hline \multicolumn{14}{|l|}{ B. Bound Tests } \\
\hline B1. Real GDP growth at historical average minus one standard deviation in 2008-09 & 6 & 6 & 8 & 10 & 11 & 16 & 17 & 18 & 19 & 19 & 19 & 19 & 19 \\
\hline B2. Export value growth at historical average minus one standard deviation in 2008-09 3/ & 6 & 7 & 9 & 11 & 12 & 17 & 17 & 18 & 19 & 19 & 19 & 19 & 19 \\
\hline B3. US dollar GDP deflator at historical average minus one standard deviation in 2008-09 & 6 & 8 & 12 & 15 & 17 & 25 & 26 & 27 & 29 & 29 & 29 & 29 & 29 \\
\hline B4. Net non-debt creating flows at historical average minus one standard deviation in 2008-09 4/ & 6 & 10 & 14 & 16 & 17 & 21 & 21 & 22 & 22 & 21 & 21 & 21 & 20 \\
\hline B5. Combination of B1-B4 using one-half standard deviation shocks & 6 & 10 & 15 & 17 & 19 & 25 & 25 & 26 & 27 & 27 & 26 & 26 & 26 \\
\hline B6. One-time 30 percent nominal depreciation relative to the baseline in $20085 /$ & 6 & 8 & 11 & 13 & 15 & 22 & 23 & 23 & 25 & 26 & 26 & 26 & 25 \\
\hline \multicolumn{14}{|c|}{ NPV of debt-to-exports ratio } \\
\hline Baseline & 62 & 65 & 79 & 93 & 104 & 143 & 148 & 152 & 154 & 153 & 151 & 146 & 143 \\
\hline \multicolumn{14}{|l|}{ A. Alternative Scenarios } \\
\hline Al. Key variables at their historical averages in $2007-26 \mathrm{l} /$ & 62 & 71 & 77 & 88 & 97 & 130 & 133 & 136 & 143 & 144 & 144 & 145 & 144 \\
\hline A2. New public sector loans on less favorable terms in 2007-26 2/ & 62 & 69 & 97 & 122 & 142 & 214 & 224 & 231 & 242 & 242 & 241 & 237 & 235 \\
\hline \multicolumn{14}{|l|}{ B. Bound Tests } \\
\hline B1. Real GDP growth at historical average minus one standard deviation in 2008-09 & 62 & 65 & 79 & 93 & 104 & 143 & 148 & 152 & 154 & 153 & 151 & 146 & 143 \\
\hline B2. Export value growth at historical average minus one standard deviation in 2008-09 3/ & 62 & 92 & 119 & 135 & 148 & 193 & 198 & 201 & 199 & 197 & 194 & 186 & 183 \\
\hline B3. US dollar GDP deflator at historical average minus one standard deviation in 2008-09 & 62 & 65 & 79 & 93 & 104 & 143 & 148 & 152 & 154 & 153 & 151 & 146 & 143 \\
\hline B4. Net non-debt creating flows at historical average minus one standard deviation in 2008-09 4/ & 62 & 112 & 151 & 160 & 167 & 194 & 195 & 194 & 181 & 177 & 173 & 163 & 159 \\
\hline B5. Combination of B1-B4 using one-half standard deviation shocks & 62 & 97 & 146 & 159 & 170 & 210 & 213 & 214 & 207 & 204 & 200 & 190 & 186 \\
\hline B6. One-time 30 percent nominal depreciation relative to the baseline in 20085 / & 62 & 65 & 79 & 93 & 104 & 143 & 148 & 152 & 154 & 153 & 151 & 146 & \\
\hline
\end{tabular}

Debt service-to-exports ratio

\section{Baseline}

A. Alternative Scenarios

Al. Key variables at their historical averages in 2008-27 $1 /$ A2. New public sector loans on less favorable terms in 2008-27 $2 /$

\section{B. Bound Tests}

B1. Real GDP growth at historical average minus one standard deviation in 2008-09 B2. Export value growth at historical average minus one standard deviation in 2008-09 3/ B3. US dollar GDP deflator at historical average minus one standard deviation in 2008-09 B4. Net non-debt creating flows at historical average minus one standard deviation in 2008-09 4 B5. Combination of B1-B4 using one-half standard deviation shocks

B6. One-time 30 percent nominal depreciation relative to the baseline in $20085 /$ 
Table 3. Rwanda: Public Sector Debt Sustainability Framework, Baseline Scenario, 2005-2027 (In percent of GDP, unless otherwise indicated)

\begin{tabular}{|c|c|c|c|c|c|c|c|c|c|c|c|c|c|c|}
\hline & \multicolumn{2}{|c|}{ Actual } & \multirow[b]{2}{*}{$\begin{array}{l}\text { Historical } \\
\text { Average } 5 /\end{array}$} & \multirow[b]{2}{*}{$\begin{array}{l}\text { Standard } \\
\text { Deviation } 5 /\end{array}$} & \multicolumn{5}{|l|}{ Estimate } & \multicolumn{5}{|c|}{ Projections } \\
\hline & 2005 & 2006 & & & 2007 & $2008 \quad 2$ & $2009 \quad 2$ & 2010 & 2011 & 2012 & $\begin{array}{l}2007-12 \\
\text { Average }\end{array}$ & 2017 & 2027 & $\begin{array}{l}2013-27 \\
\text { Average }\end{array}$ \\
\hline $\begin{array}{l}\text { Public sector debt } 1 / \\
\text { o/w foreign-currency denominated }\end{array}$ & $\begin{array}{l}84.0 \\
70.4\end{array}$ & $\begin{array}{l}28.5 \\
16.6\end{array}$ & & & $\begin{array}{l}26.3 \\
16.5\end{array}$ & $\begin{array}{l}25.2 \\
15.5\end{array}$ & $\begin{array}{l}27.5 \\
19.3\end{array}$ & $\begin{array}{l}30.0 \\
22.8\end{array}$ & $\begin{array}{l}31.5 \\
25.1\end{array}$ & $\begin{array}{l}32.7 \\
26.7\end{array}$ & & $\begin{array}{l}39.6 \\
33.9\end{array}$ & $\begin{array}{l}40.4 \\
34.5\end{array}$ & \\
\hline Change in public sector debt & 0.2 & -55.5 & & & -2.3 & -1.1 & 2.3 & 2.5 & 1.5 & 1.1 & & 1.0 & -0.5 & \\
\hline Identified debt-creating flows & -15.5 & .56 .2 & & & -3.6 & -2.3 & 1.8 & 2.1 & 1.4 & 1.0 & & 0.8 & -0.8 & \\
\hline Primary deficit & -1.4 & -0.5 & 0.5 & 1.6 & -0.1 & 0.7 & 3.5 & 4.0 & 3.4 & 3.2 & 2.4 & 3.3 & 1.7 & 2.8 \\
\hline Revenue and grants & 26.3 & 23.8 & & & 24.8 & 27.0 & 23.8 & 22.8 & 23.6 & 23.1 & & 22.1 & 22.3 & \\
\hline of which: grants & 12.7 & 10.6 & & & 11.3 & 13.3 & 9.9 & 8.9 & 9.4 & 8.8 & & 7.0 & 5.0 & \\
\hline Primary (noninterest) expenditure & 24.9 & 23.2 & & & 24.7 & 27.6 & 27.3 & 26.8 & 27.0 & 26.3 & & 25.4 & 24.0 & \\
\hline Automatic debt dynamics & -13.2 & -13.2 & & & -3.2 & -2.8 & -1.6 & -1.7 & -2.0 & -2.1 & & -2.5 & -2.5 & \\
\hline Contribution from interest ratelegrowth differential & -6.9 & -5.6 & & & -2.2 & -1.6 & -1.5 & -1.7 & -2.0 & -2.1 & & -2.5 & -2.5 & \\
\hline of which: contribution from average real interest rate & -1.3 & -1.3 & & & -0.6 & -0.2 & -0.2 & -0.3 & -0.4 & -0.4 & & -0.4 & -0.3 & \\
\hline of which : contribution from real GDP growth & -5.5 & -4.3 & & & -1.6 & -1.5 & -1.3 & -1.4 & -1.6 & -1.7 & & -2.1 & -2.2 & \\
\hline Contribution from real exchange rate depreciation & -6.3 & -7.6 & & & -1.0 & -1.1 & 0.0 & 0.0 & 0.0 & 0.0 & & $\ldots$ & $\ldots$ & \\
\hline Other identified deb-creating flows & -0.9 & -42.5 & & & -0.2 & -0.2 & -0.1 & -0.1 & -0.1 & -0.1 & & 0.0 & 0.0 & \\
\hline Privatization receipts (negative) & 0.0 & 0.0 & & & 0.0 & 0.0 & 0.0 & 0.0 & 0.0 & 0.0 & & 0.0 & 0.0 & \\
\hline Recognition of implicit or contingent liabilities & 0.0 & 0.0 & & & 0.0 & 0.0 & 0.0 & 0.0 & 0.0 & 0.0 & & 0.0 & 0.0 & \\
\hline Debt relief (HIPC and other) & -0.9 & -42.5 & & & -0.2 & -0.2 & -0.1 & -0.1 & -0.1 & -0.1 & & 0.0 & 0.0 & \\
\hline Other (specify, e.g. bank recapitalization) & 0.0 & 0.0 & & & 0.0 & 0.0 & 0.0 & 0.0 & 0.0 & 0.0 & & 0.0 & 0.0 & \\
\hline Residual, including asset changes & 15.7 & 0.7 & & & 1.3 & 1.3 & 0.5 & 0.3 & 0.2 & 0.1 & & 0.2 & 0.3 & \\
\hline NPV of public sector debt & 13.6 & 16.6 & & & 14.9 & 16.1 & 16.2 & 16.4 & 16.8 & 17.4 & & 21.1 & 20.2 & \\
\hline o/w foreign-currency denominated & 0.0 & 4.6 & & & 5.1 & 6.4 & 8.0 & 9.3 & 10.4 & 11.4 & & 15.3 & 14.4 & \\
\hline o/w external & $\ldots$ & 4.6 & & & 5.1 & 6.4 & 8.0 & 9.3 & 10.4 & 11.4 & & 15.3 & 14.4 & \\
\hline NPV of contingent liabilities (not included in public sector debt) & $\ldots$ & $\ldots$ & & & $\ldots$ & $\ldots$ & $\ldots$ & $\ldots$ & $\ldots$ & $\ldots$ & & $\ldots$ & $\ldots$ & \\
\hline Gross financing need $2 /$ & 1.5 & 1.6 & & & 3.3 & 4.6 & 6.7 & 6.4 & 5.5 & 5.2 & & 6.4 & 7.0 & \\
\hline NPV of public sector debt-to-revernule and grants ratio (in percent) & 51.9 & 70.0 & & & 60.1 & 59.8 & 68.1 & 72.0 & 71.4 & 75.1 & & 95.2 & 90.5 & \\
\hline NPV of public sector debt-to-revenulu ratio (in percent) & 100.5 & 126.4 & & & 110.4 & 118.2 & 117.1 & 117.6 & 119.1 & 121.4 & & 139.0 & 116.5 & \\
\hline o/w external 3/ & & 35.3 & & & 37.8 & 47.3 & 57.7 & 66.3 & 73.6 & 80.0 & & 100.8 & 82.7 & \\
\hline Dets service-to-reverue and grants ratio (in percent) $4 /$ & 9.1 & 7.1 & & & 4.8 & 4.4 & 4.6 & 4.0 & 3.5 & 3.5 & & 3.2 & 4.7 & \\
\hline Debt service-to-reverue ratio (in percent) 44 & 17.5 & 12.8 & & & 8.9 & 8.8 & 7.8 & 6.6 & 5.8 & 5.6 & & 4.6 & 6.0 & \\
\hline Primary deficit that stabilizes the deb-to-GDP ratio & -1.6 & 55.0 & & & 2.1 & 1.7 & 1.2 & 1.5 & 1.9 & 2.0 & & 2.3 & 2.1 & \\
\hline \multicolumn{15}{|l|}{ Key macroeconomic and fiscal assumptions } \\
\hline Nominal GDP (local currency) & 1327 & 1583 & & & 1826 & 2052 & 2275 & 2523 & 2801 & 3110 & & 5247 & 14446 & \\
\hline Real GDP growth (in percent) & 7.1 & 5.5 & 10.1 & 7.0 & 6.0 & 6.0 & 5.6 & 5.5 & 5.7 & 5.7 & 5.8 & 5.7 & 5.7 & 5.7 \\
\hline Average nominal interest rate on forex dett (in percent) & 0.6 & 0.7 & 0.8 & 0.1 & 0.7 & 0.6 & 0.8 & 0.8 & 0.8 & 0.8 & 0.7 & 0.8 & 0.8 & 0.8 \\
\hline Average real interest rate on domestic currency debt (in percent) & $\ldots$ & -7.4 & -7.4 & & -4.2 & -0.7 & -0.7 & -1.1 & -1.2 & -1.2 & -1.5 & -0.3 & 1.6 & 0.3 \\
\hline Real exchange rate depreciation (in percent, + indicates depreciation) & .8 .2 & -11.4 & 5.5 & 19.0 & -6.3 & $\ldots$ & $\ldots$ & $\ldots$ & $\ldots$ & $\ldots$ & $\ldots$ & $\ldots$ & $\ldots$ & $\ldots$ \\
\hline Inflation rate (GDP deflator, in percent) & 8.9 & 13.1 & 4.5 & 12.3 & 8.8 & 6.0 & 5.0 & 5.1 & 5.0 & 5.0 & 5.8 & 5.0 & 5.0 & 5.0 \\
\hline Growth of real primary spending (deflated by GDP deflator, in percent) & 15.4 & -1.6 & 11.5 & 10.2 & 12.7 & 18.7 & 4.3 & 3.5 & 6.4 & 3.1 & 8.1 & 4.6 & 4.7 & 5.1 \\
\hline Grant telement of new external borrowing (in percent) & 0.6 & 0.6 & 0.6 & 0.0 & 0.6 & 0.6 & 0.6 & 0.6 & 0.6 & 0.6 & 0.6 & 0.6 & 0.6 & $\ldots$ \\
\hline \multicolumn{15}{|c|}{$\begin{array}{l}\text { Sources: Country authorities; and Fund staffe stimates and projections. } \\
1 / \text { [ndicate coverage of public sector, e.g., geneneral government or nonfinancial public sector. Also whether net or gross debt is used.] }\end{array}$} \\
\hline \multicolumn{15}{|c|}{ 2/ Gross financing need is defined as the primary deficit plus debt service plus the stock of short-erm debt a the end of the last priod. } \\
\hline \multicolumn{15}{|c|}{$3 /$ Revenues excluding grants. } \\
\hline 4/ Det service is defined as the sum of interest and amortization of medi & rm debt. & & & & & & & & & & & & & \\
\hline 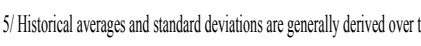 & & & & & & & & & & & & & & \\
\hline
\end{tabular}


Table 4. Rwanda: Sensitivity Analysis for Key Indicators of Public Debt 2007-2027

Baseline
A. Alternative scenarios
A1. Real GDP growth and primary balance are at historical averages
A2. Revenue is unchanged from 2007
A3. Permanently lower GDP growth $1 /$

Projections

\begin{tabular}{llllllll}
2007 & 2008 & 2009 & 2010 & 2011 & 2012 & 2017 & 2027 \\
\hline
\end{tabular}

NPV of Debt-to-GDP Ratio

\section{B. Bound tests}

B1. Real GDP growth is at historical average minus one standard deviations in 2008-2009

B2. Primary balance is at historical average minus one standard deviations in 2008-2009

B3. Combination of B1-B2 using one half standard deviation shocks

B4. One-time 30 percent real depreciation in 2008

B5. 10 percent of GDP increase in other debt-creating flows in 2008

NPV of Debt-to-Revenue Ratio 2/

Baseline

$\begin{array}{llllllll}15 & 16 & 16 & 16 & 17 & 17 & 21 & 20\end{array}$

A. Alternative scenarios

A1. Real GDP growth and primary balance are at historical averages

A2. Revenue is unchanged from 2007

A3. Permanently lower GDP growth 1 /

\section{B. Bound tests}

B1. Real GDP growth is at historical average minus one standard deviations in 2008-2009

B2. Primary balance is at historical average minus one standard deviations in 2008-2009

B3. Combination of B1-B2 using one half standard deviation shocks

B4. One-time 30 percent real depreciation in 2008

B5. 10 percent of GDP increase in other debt-creating flows in 2008

Debt Service-to-Revenue Ratio 2/

Baseline

A. Alternative scenarios

A1. Real GDP growth and primary balance are at historical averages

A2. Revenue is unchanged from 2007

A3. Permanently lower GDP growth 1

$\begin{array}{rrrrrrrr}15 & 15 & 12 & 8 & 6 & 4 & -6 & -17 \\ 15 & 16 & 17 & 17 & 18 & 19 & 30 & 63 \\ 15 & 17 & 17 & 18 & 20 & 22 & 38 & 98\end{array}$

\section{B. Bound tests}

B1. Real GDP growth is at historical average minus one standard deviations in 2008-2009

B2. Primary balance is at historical average minus one standard deviations in 2008-2009

B3. Combination of B1-B2 using one half standard deviation shocks

B4. One-time 30 percent real depreciation in 2008

B5. 10 percent of GDP increase in other debt-creating flows in 2008

$\begin{array}{llllllll}15 & 17 & 18 & 19 & 20 & 21 & 30 & 41 \\ 15 & 17 & 16 & 16 & 16 & 17 & 20 & 19 \\ 15 & 17 & 14 & 14 & 15 & 16 & 20 & 20 \\ 15 & 18 & 17 & 16 & 16 & 16 & 18 & 17 \\ 15 & 26 & 26 & 27 & 27 & 28 & 33 & 36\end{array}$

Sources: Country authorities; and Fund staff estimates and projections.

1/ Assumes that real GDP growth is at baseline minus one standard deviation divided by the square root of 20 (i.e., the length of the projection period).

$2 /$ Revenues are defined inclusive of grants. 
Figure 2. Rwanda: Indicators of Public Debt Under Alternative Scenarios, 2007-2027 1/

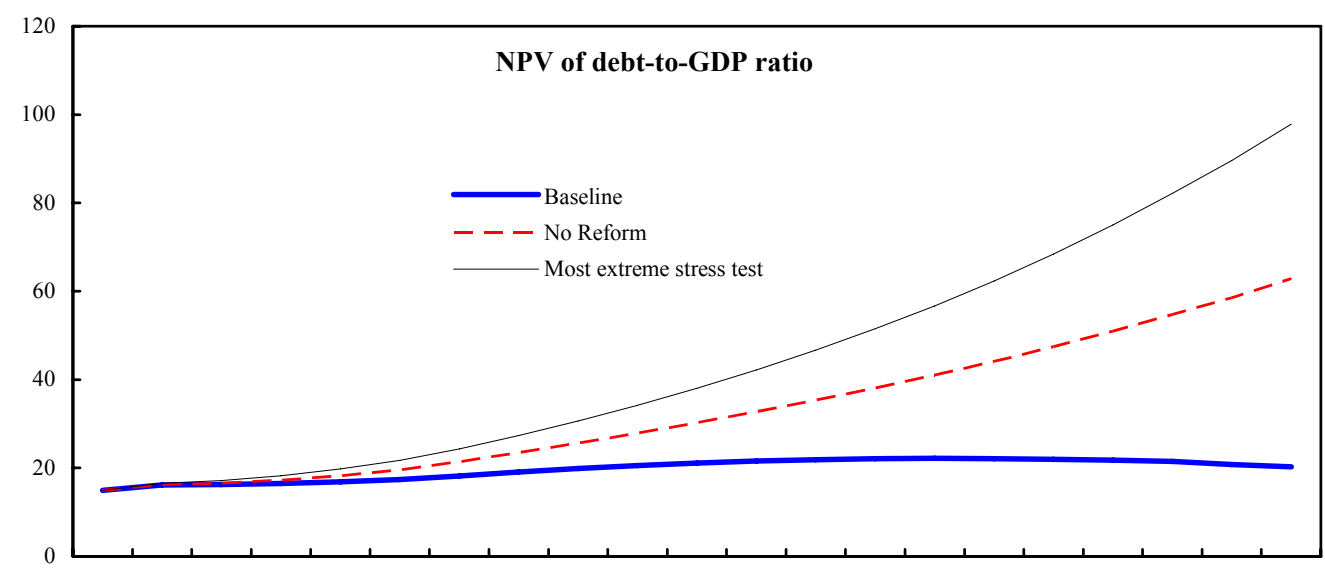

200720082009201020112012201320142015201620172018201920202021202220232024202520262027

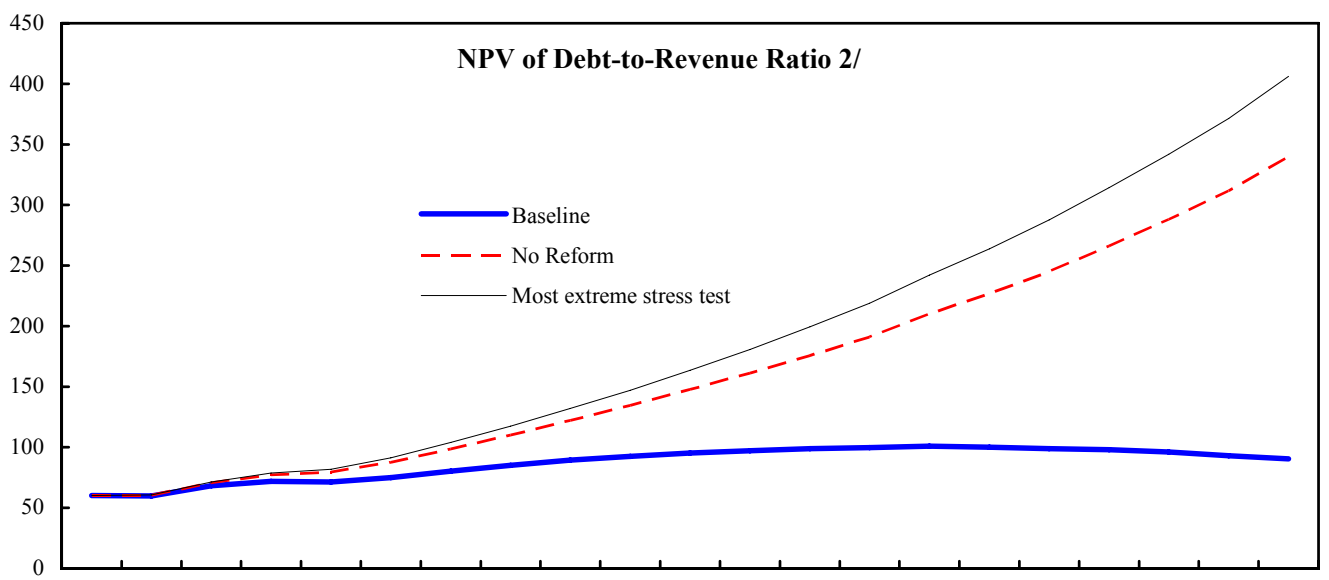

200720082009201020112012201320142015201620172018201920202021202220232024202520262027

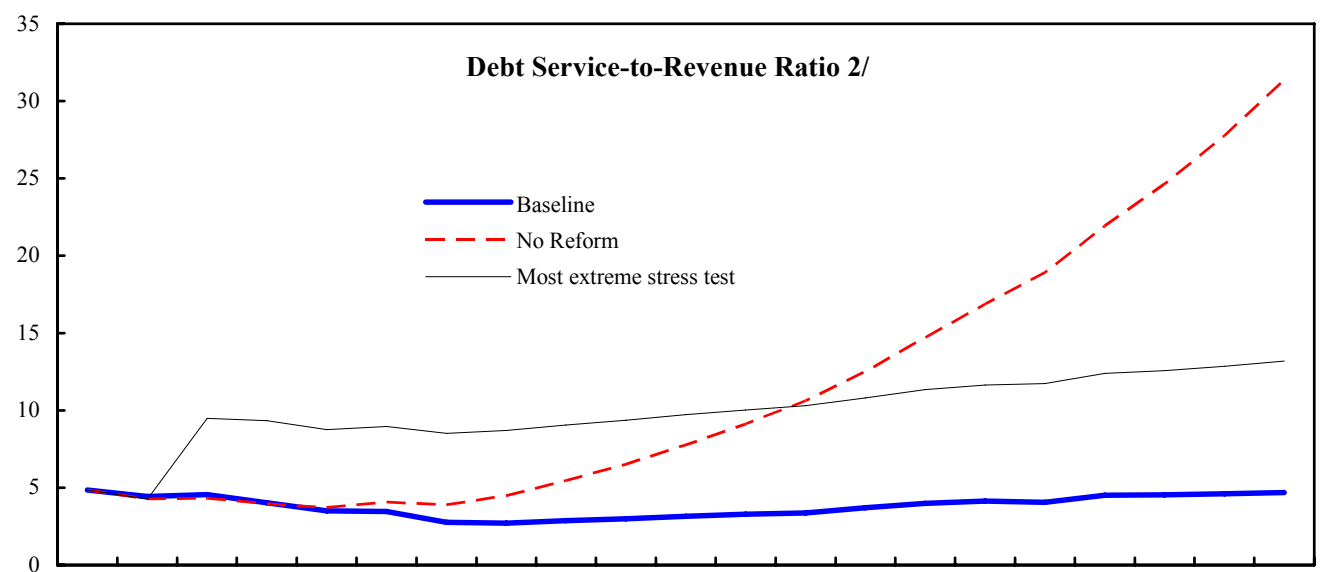

200720082009201020112012201320142015201620172018201920202021202220232024202520262027

Source: Staff projections and simulations.

1/ Most extreme stress test is test that yields highest ratio in 2017.

2/ Revenue including grants. 


\section{INTERNATIONAL MONETARY FUND}

RWANDA

\section{Third Review Under the Three-Year Arrangement Under the Poverty Reduction and Growth Facility and Request for Waiver of Nonobservance of Performance Criterion-Informational Annex}

Prepared by the African Department (In collaboration with other departments)

Approved by Hugh Bredenkamp and Mark Plant

February 14, 2008

- $\quad$ Relations with the Fund. Describes financial and technical assistance by the IMF and provides information on the safeguards assessment and exchange system. Outstanding Fund credit was SDR5.13 million (6.41 percent of quota) at end-December 2007. Completion of the third review would allow the disbursement of SDR1.14 million.

- $\quad$ Relations with the World Bank Group. Describes World Bank Group program and portfolio and provides statement of IFC investments.

- $\quad$ Statistical Issues. Assesses the quality of statistical data. Although economic data are generally adequate for surveillance, weaknesses hamper economic analysis. 


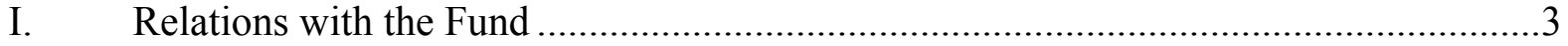

II. Relations with the World Bank Group.................................................................

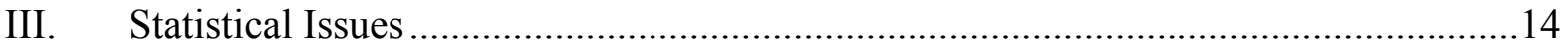




\section{Rwanda: Relations with the Fund}

(As of December 31, 2007)

I. Membership Status: Joined: September 30, 1963

Article VIII

II. General Resources Account:

$\underline{\text { SDR million }}$

80.10

Quota

80.11

Fund holdings of currency

0.00

percent Quota

Reserve position in Fund

100.00

100.02

0.00

III. SDR Department:

$\underline{\text { SDR million }}$

percent Allocation

Net cumulative allocation

13.70

100.00

Holdings

15.23

111.16

IV. Outstanding Purchases and Loans:

PRGF arrangements

$\underline{\text { SDR million }}$

percent Quota

5.13

6.41

V. Latest Financial Arrangements:

$\begin{array}{lcccc}\text { Type } & \begin{array}{c}\text { Approval } \\ \text { date }\end{array} & \begin{array}{c}\text { Expiration } \\ \text { date }\end{array} & \begin{array}{c}\text { Amount } \\ \text { approved } \\ \text { (SDR million) }\end{array} & \begin{array}{c}\text { Amount drawn } \\ \text { (SDR million) }\end{array} \\ \text { PRGF } & \text { Jun 12, 2006 } & \text { Jun 11, 2009 } & \frac{8.01}{3.42} & 4.00 \\ \text { PRGF } & \text { Aug 12, 2002 } & \text { Jun 11, 2006 } & 4.00 & 61.88 \\ \text { PRGF } & \text { Jun 24, 1998 } & \text { Apr 30, 2002 } & 71.40 & \end{array}$

VI. Projected Payments to the Fund (SDR million; based on existing use of resources and present holdings of SDRs):

Principal

$\underline{2008}$

Charges/Interest

0.03

Total

0.03

$\underline{2009}$

Forthcoming

VII. Implementation of HIPC Initiative:

Enhanced

framework

I Commitment of HIPC assistance

Decision point date

Dec 2000 
Assistance committed by all creditors

(US\$ million) ${ }^{36}$

695.50

Of which: IMF assistance (US\$ million)

63.40

(SDR equivalent in millions)

46.79

Completion point date

Apr 2005

II Delivery of IMF assistance (SDR million)

Amount disbursed

Interim assistance

Completion point

Additional disbursement of interest income ${ }^{37}$

Total disbursements

\section{Implementation of MDRI Assistance}

I Total Debt Relief (SDR Million) ${ }^{38}$

Of which: MDRI

HIPIC

32.55

II Debt Relief by Facility (SDR million)

Delivery Date

GRA

PRGF Total

January 2006

NA

$52.74 \quad 52.74$

Decision point - point at which the IMF and the World Bank determine whether a country qualifies for assistance under the HIPC Initiative and decide on the amount of assistance to be committed.

\footnotetext{
${ }^{36}$ Assistance committed under the original framework is expressed in net present value (NPV) terms at the completion point, and assistance committed under the enhanced framework is expressed in NPV terms at the decision point. Hence these two amounts can not be added.

${ }^{37}$ Under the enhanced framework, an additional disbursement is made at the completion point corresponding to interest income earned on the amount committed at the decision point but not disbursed during the interim period.

${ }^{38}$ The Multilateral Debt Relief Initiative (MDRI) provides 100 percent debt relief to eligible member countries that are qualified for the assistance. The debt relief covers the full stock of debt owed to the Fund as of end2004 which remains outstanding at the time the member qualifies for such debt relief. The MDRI is financed by bilateral contributions and the Fund's own resources, as well as the resources already disbursed to the member under the HIPC Initiative (see Section VII above).
} 
Interim assistance - amount disbursed to a country during the period between decision and completion points, up to 20 percent annually and 60 percent in total of the assistance committed at the decision point (or 25 percent and 75 percent, respectively, in exceptional circumstances).

Completion point - point at which a country receives the remaining balance of its assistance committed at the decision point, together with an additional disbursement of interest income as defined in footnote 3 above. The timing of the completion point is linked to the implementation of pre-agreed key structural reforms (i.e., floating completion point).

\section{Safeguards Assessments:}

Under the Fund's safeguards assessment policy, the National Bank of Rwanda (NBR) was subject to a safeguards assessment with respect of the PRGF arrangement approved on June 12, 2006. The update assessment proposed recommendations to address continuing vulnerabilities in the external audit and financial reporting areas. The implementation of these measures is being monitored by IMF staff.

\section{Exchange System:}

The Rwanda franc was pegged to the SDR until March 6, 1995, when Rwanda adopted a market-determined exchange rate system. However, the exchange rate regime was reclassified to a conventional fixed peg in the IMF's September 2006 Quarterly Report on Exchange Arrangements. On December 1998, Rwanda accepted the obligations under Article VIII, Sections 2, 3 and 4 of the IMF, and maintains a system free of restrictions on the making of payments and transfers for current international transactions. In 2001, a foreign exchange auction system was put in place with technical assistance from MFD. Since February 7, 2001, auctions have been taking place on a weekly basis and the foreign exchange auctions impose a limit of $+/$ - RF 5 to the margin by which the exchange rate can vary from the previous day. The rate used is the rate for the last sale of foreign exchange to banks. A new system under which the BNR will sell foreign exchange to banks on demand at the average accounting rate for that day was introduced on June 25, 2007.

\section{Article IV Consultation:}

Rwanda is on the revised 24-month consultation cycle. The Executive Board discussed the staff report for the 2006 Article IV consultation (IMF Country Report No. 07/80) on January $29,2007$. 


\section{FSAP Participation, ROSCs, and OFC Assessments:}

A Report on Observance of Standards and Codes on Fiscal Transparency (ROSC) was issued in July 2003. A Financial Sector Assessment Program (FSAP) has taken place in February 2005. Rwanda has not had an Offshore Financial Center (OFC) assessment. 


\section{Technical Assistance:}

1999 FAD long-term experts, on tax policy, on budget preparation, and on treasury management.

1999 MFD long-term general advisor to governor of NBR.

1999 MFD experts on banking supervision and foreign exchange market operations.

2000 FAD experts on budget execution and on tax policy.

2000 MFD experts on foreign exchange market operations, and banking supervision.

2000 STA mission on money and banking statistics.

2000 STA mission on balance of payments statistics.

2001 FAD experts on expenditure management and on tax policy.

2001 FAD mission on tax policy.

2001 MFD mission on foreign exchange policy, monetary policy, and banking supervision.

2001 MFD expert on monetary policy implementation.

2001 FAD mission on assessment of tracking of poverty reducing expenditure, and the fiscal ROSC.

2001 MFD expert on banking supervision.

2001 FAD experts on expenditure management, and on tax policy (until mid-year).

2002 MFD expert on banking supervision (until November).

2002 MFD expert on monetary and foreign exchange rate policy.

2002 AFRITAC East work plan mission.

2003 AFRITAC East mission on statistical issues.

2003 AFRITAC East expert on Organic Budget Law.

2003 FAD mission on fiscal ROSC and budget management system.

2003 AFRITAC East mission on developing the market for government treasury bills.

2003 FAD mission on reform of investment incentives and tax reform.

2003 MFD expert on monetary and foreign exchange rate policy.

2003 MFD expert on banking supervision and regulation.

2003 MFD missions on banking supervision.

2003 MFD mission on foreign reserves management.

2003 STA multi-sector statistics mission.

2003 FAD mission on Decentralization.

2003 FAD mission on revenue administration.

2004 AFRITAC East expert on financial regulations.

2004 AFRITAC East mission on treasury reforms.

2004 AFRITAC East expert on implementing cash flow planning and banking arrangements.

2004 FAD tax administration expert on strengthening of revenue administration.

2004 FAD mission on revenue administration.

2004 MFD/LEG mission on Anti-Money Laundering and Combating the Financing of Terrorism. 
2004 MFD expert on banking supervision and regulation.

2004 MFD expert on monetary policy, monetary operations, and money markets.

2004 MFD missions on on-site banking supervision.

2005 AFRITAC East expert follow up on cash management.

2005 MFD/LEG mission on Anti-Money Laundering and Combating the Financing of Terrorism.

2005 MFD mission on financial statements of specific bank.

2005 MFD-WB joint FSAP mission.

2005 LEG mission on customs legislation.

2005 STA mission on Balance of Payments statistics.

2005 LEG mission on tax legislation.

2005 FAD mission on public accounting: decentralized accounting for central government.

2005 FAD expert on tax administration.

2005 MFD resident expert on monetary operations, monetary policy, money markets.

2005 MFD expert on banking supervision.

2005 LEG mission on drafting an amendment to the banking law.

2005 MFD mission on banking supervision and bank restructuring.

2006 AFRITAC East experts on establishing intergovernmental fiscal unit in the MOF.

2006 FAD advisor trade facilitation.

2006 MFD FSAP-follow up advisory mission on monetary and foreign exchange operations and NBR internal audit.

2006 LEG mission to strengthen legal and regulatory framework for bank supervision.

2006 AFRITAC East advisors on finalization of OBL and financial regulations

2007 AFRITAC East advisors on workshops for implementation of OBL and financial regulations

2007 MCM expert on bank restructuring.

2007 MCM expert on foreign exchange operations.

\section{Resident Representative:}

Mr. Lars Holger Engström assumed his duties as Resident Representative in February 2005.

\section{Management Visit:}

The Deputy Managing Director, Mr. Portugal, visited Rwanda during May 3-5, 2007. 


\section{Rwanda: Relations with the World Bank Group}

(As of January 2008)

\section{Partnership for Rwanda's development strategy}

Donor agencies have been key players in Rwanda since the genocide. With the support from the international community, Rwanda has made notable progress along an ambitious path of reconstruction, national reconciliation, and economic reform. Over the past six years, the Government has made commendable efforts, based on its first Poverty Reduction Strategy Paper (PRSP-1), to reduce poverty and improve living conditions of the poor. PRSP-1 was completed in June 2002 and covered the period 2002-06. It was supported and discussed by the Boards of the IDA and the IMF on August 12, 2002. PRSP-1 aimed to reduce poverty by half by 2015 , through a private and rural sector-led strategy; the first PRSP also stressed the need to address the issues of HIV/AIDS, shelter for the homeless, the demobilization of excombatants and the resettlement and reintegration of all refugees. The strategy focused mainly on six priority areas: (1) rural development and agricultural transformation; (2) human development; (3) economic infrastructure; (4) good governance; (5) private sector development; and (6) institutional capacity building - as the focus for public actions on poverty reduction. Civil society, government agencies and ministries, and donors were all actively involved in the PRSP-1 process and monitoring. Three annual progress reports were prepared during the implementation of PRSP-1, the last of which was completed in July 2005. The corresponding Bank-Fund Joint Staff Advisory Note (JSAN) was produced in March 2006.

A second poverty reduction strategy, the Economic Development and Poverty Reduction Strategy (EDPRS), was completed in September 2007. The EDPRS refocuses Rwanda's priority on growth and human development, with an emphasis on decentralization, and a greater role for the private sector. The EDPRS provides a road map for the next five years (2008-2012) to government, development partners, the private sector and civil society indicating where Rwanda wants to go, what it needs to do to get there, what the journey is going to cost and how it will be financed. The strategy provides a medium-term framework for achieving the Millennium Development Goals, in the context of the country's long term development aspirations embodied in Rwanda's Vision 2020.

The JSAN of the EDPRS will be presented to the Boards of the IDA and the IMF in February 2008.

\section{World Bank Group Program and Portfolio}

The last Country Assistance Strategy (CAS) for Rwanda, covering FY 2002-06, was discussed by the World Bank Board in December 2002. An Interim Strategy Note (ISN), approved by the Bank Board in September 2006, extended the CAS through FY08 to ensure that the next CAS will be aligned with Rwanda's second PRSP, called the Economic Development and Poverty Reduction Strategy (EDPRS). Both the first CAS and ISN set out an assistance program consistent with the country's PRSP-1, and emphasized the need to 
move progressively from project-based approaches to budget support. In line with that approach, a series of three programmatic operations - i.e. Poverty Reduction Support Credits/Grants (PRSGs) - was presented to the Bank Board in October 2004, October 2005, and in December 2006. This first series of PRSGs supported Rwanda's PRSP-1 in three priority areas: private sector development; improvement in the access and quality of socioeconomic services, mainly in education, health, water, and energy; and in the improvement in economic governance. The PRSG was also the instrument for the Bank to support the process of donor harmonization.

The Bank has prepared a fourth PRSG which will be presented to the Board in February 2008. PRSG-4 will be the first in a series of grants designed to support Rwanda's EDPRS. This new series of grants will support the GoR's efforts to accelerate growth in the medium term, and sustain improvements in social indicators.

International Development Agency (IDA) Program: Rwanda joined the World Bank in 1963. Since then, the country has been approved for 69 IDA credits and grants totaling approximately US\$1.4 billion. As of January 2008, there were twelve ongoing operations with a commitment value of about US\$300 million and an undisbursed balance of roughly US\$113 million.

Overall, IDA has financed projects in (i) infrastructure, particularly road construction and maintenance, electricity and water supply, and sanitation infrastructure; (ii) agriculture, rural development, and forestry; (iii) social infrastructure, including health and population, and education and training; (iv) private sector development, public enterprise reform, financial development, and technical assistance; and (v) four policy-based quick-disbursing operations (IRC and PRSG1-3). During the immediate post-genocide period, IDA financed two emergency budget support operations and a social fund-type project, and restructured its prewar portfolio of investment projects to meet the high-priority needs associated with the emergency and the transition from conflict to development.

International Finance Corporation (IFC) Program: The following outlines the IFC program in Rwanda:

- Infrastructure: IFC is working with the World Bank and GoR to explore financing opportunities for the Lake Kivu Methane Gas Project (KPI). IFC has committed US\$7.5 million to M/s Intraspeed SA Rwanda Ltd (ISARL), a major freight and forwarding company in the Great Lakes Region, to help upgrade and expand the company's freight hauling capabilities.

- Financial sector: In November 2007, IFC signed a US\$2.0 million trade finance agreement with Banque Commerciale du Rwanda (BCR). It is also currently considering long term credit lines to a few banks. IFC is also developing a private school program through local financial institutions. IFC also intends to develop a housing finance program in Rwanda in the next 12 months. 
- Tourism: IFC also committed US\$8.0 million for the modernization/expansion of the Kigali Serena hotel and the Kivu Sun in Kibuye, recently acquired by Tourism Promotion Services of the Aga Khan Fund for Economic development (AKFED). IFC also committed US\$2.5 million to Milkor Hotels for the rehabilitation and refurbishment of the Hotel Mille Collines.

- Privatization: IFC is advising the Government of Rwanda on the privatization of Rwanda Air.

- PEP-Africa: Technical assistance programs in Financial and SME sectors: Rwanda Leasing Program and Rwanda Entrepreneurship Program were launched on March 15, 2007. IFC is also developing a Gender Entrepreneurship Markets (GEM) Program in Rwanda.

Multilateral Investment Guarantee Agency (MIGA) Program: Rwanda signed and ratified the MIGA Convention on October 27, 1989. On September 27, 2002, it became a full member of MIGA with the completion of its membership requirements, including payment of the usable currency and the local currency portions of its initial subscription, and deposit of the promissory note. The membership was followed by Rwanda's election to MIGA's Board of Directors during the World Bank/IMF annual meetings held in Washington.

Rwanda is one of the 16 post-conflict countries in the region on which MIGA is focusing as part of its post-conflict strategy. To date, there have been no requests for guarantees coverage of projects in the country, and thus the Agency's efforts have focused on complementing the Bank Group's strategy of accelerating private sector-led growth in the country. In consultation with the Bank, MIGA's technical assistance team undertook an assessment to assist Rwanda in creating a national investment and trade promotion capability and made recommendations on the proposed Rwanda Investment Authority, as well as on the medium to long-term prospects for the country to attract foreign investment. Previously, MIGA collaborated with the World Bank to advise on the establishment of the Rwanda Investment and Export Promotion Agency (RIEPA) and provided considerable information on investment prospects in the country. FIAS has carried out an assessment of the strengths and weaknesses of RIEPA, meeting with RIEPA staff, board, and stakeholders, and surveying some of its private sector clients. The assessment was presented to RIEPA and the GoR in October 2007 and was well received. The assessment includes a FIAS technical assistance plan for RIEPA, including schedules and a budget. RIEPA selected two priority areas to focus on immediately: support in elaboration of the new corporate plan, and improving performance and a client tracking system.

In addition, MIGA's on-line investment promotion services (www.fdixchange.com and www.ipanet.net) feature approximately 90 documents on investment opportunities and the related business, legal and regulatory environment in Rwanda. 


\section{World Bank staff}

Questions may be referred to Colin Bruce, Country Director (Tel. 5368+6441 / 254-20-3226441) and Kene Ezemenari, Senior Economist (Tel.202-458-5559). 


\section{Table 1: Summary of Bank-Fund Collaboration}

\begin{tabular}{|c|c|c|c|}
\hline Thematic area & Areas of collaboration & Bank & Fund \\
\hline \multirow[t]{2}{*}{$\begin{array}{l}\text { Macroeconomic stability and } \\
\text { development }\end{array}$} & $\begin{array}{l}\text { Development agenda in poverty } \\
\text { reduction goals. }\end{array}$ & $\begin{array}{l}\text { Complement IMF's macroeconomic } \\
\text { policy with various broad structural } \\
\text { and sectoral work through lending and } \\
\text { capacity building especially in areas } \\
\text { such as budget management, energy, } \\
\text { infrastructure, banking, } \\
\text { telecommunications sectors. }\end{array}$ & $\begin{array}{l}\text { IMF leads the policy dialogue and } \\
\text { macroeconomic policies including } \\
\text { fiscal and monetary policies. IMF } \\
\text { has been supporting Rwanda } \\
\text { through several arrangements under } \\
\text { ESAF/PRGF. }\end{array}$ \\
\hline & $\begin{array}{l}\text { Collaboration in the areas of } \\
\text { growth oriented reforms of the } \\
\text { government. }\end{array}$ & $\begin{array}{l}\text { Technical assistance in macro } \\
\text { framework and related issues. }\end{array}$ & $\begin{array}{l}\text { Technical assistance for improving } \\
\text { tax administration }\end{array}$ \\
\hline \multirow[t]{2}{*}{$\begin{array}{l}\text { Public finance management } \\
\text { and governance }\end{array}$} & $\begin{array}{l}\text { A joint Bank and Fund } \\
\text { assessment of the government's } \\
\text { capacity to track poverty } \\
\text { expenditures in July 2004, } \\
\text { which highlighted the key areas } \\
\text { for improvement. }\end{array}$ & $\begin{array}{l}\text { The Bank has been providing } \\
\text { assistance to the government to } \\
\text { improve the capacity and quality of the } \\
\text { budget process through a series of } \\
\text { public expenditure reviews. Recently } \\
\text { the Bank completed Financial } \\
\text { Accountability Review and Action } \\
\text { Plan (FARAP) and expected to support } \\
\text { further through a Country Financial } \\
\text { Accountability Assessment (CFAA). }\end{array}$ & \multirow[t]{2}{*}{$\begin{array}{l}\text { IMF TA missions have been fielded } \\
\text { in the areas of financial } \\
\text { management, fiscal decentralization, } \\
\text { and revenue management. Technical } \\
\text { assistance provided in revenue } \\
\text { management and modernization. }\end{array}$} \\
\hline & $\begin{array}{l}\text { Strengthening capacities in the } \\
\text { areas of financial accountability } \\
\text { and budget monitoring. }\end{array}$ & $\begin{array}{l}\text { Financing and provision of technical } \\
\text { assistance in expenditure tracking } \\
\text { surveys and procurement reform. } \\
\text { The Bank supports reform through the } \\
\text { public sector capacity building project. }\end{array}$ & \\
\hline $\begin{array}{l}\text { Structural and policy reforms } \\
\text { and financial sector }\end{array}$ & $\begin{array}{l}\text { Collaboration in key } \\
\text { institutional and structural } \\
\text { reforms including an MTEF } \\
\text { approach to budget planning, } \\
\text { legal and judicial reform in } \\
\text { establishing commercial courts } \\
\text { and other regulatory reforms. } \\
\end{array}$ & $\begin{array}{l}\text { The Bank has provided support in the } \\
\text { restructuring of the banking sector, and } \\
\text { addressing the problem of non- } \\
\text { performing loans. The Bank is also } \\
\text { providing assistance to develop the } \\
\text { micro-finance sector and the control of } \\
\text { money laundering. }\end{array}$ & $\begin{array}{l}\text { The Fund has been providing TA in } \\
\text { banking supervision and prudential } \\
\text { regulation. IMF is also providing } \\
\text { assistance to the Central Bank in } \\
\text { monetary policy analysis, banking } \\
\text { supervision, and internal audit. }\end{array}$ \\
\hline $\begin{array}{l}\text { Infrastructure and private } \\
\text { sector development }\end{array}$ & $\begin{array}{l}\text { Collaboration in business } \\
\text { friendly policies especially in } \\
\text { the areas of taxation, budget, } \\
\text { and legal and institutional } \\
\text { development. } \\
\text { Collaboration in reforming the } \\
\text { financial sector. }\end{array}$ & $\begin{array}{l}\text { The Bank has been supporting this } \\
\text { area through many infrastructure } \\
\text { projects in transport, water/sanitation, } \\
\text { and energy. The competitiveness and } \\
\text { enterprise development project } \\
\text { (CEDP) is supporting reforms in } \\
\text { telecommunications, privatization of } \\
\text { the current telephone monopoly and } \\
\text { tea factories. Banking sector reforms } \\
\text { and the privatization process have been } \\
\text { supported by the CEDP and the } \\
\text { Institutional Reform Credit (IRC). }\end{array}$ & $\begin{array}{l}\text { The Fund has been complementing } \\
\text { the Bank work through policy } \\
\text { dialogue and TA on fiscal and } \\
\text { monetary policies. }\end{array}$ \\
\hline $\begin{array}{l}\text { Agriculture and rural } \\
\text { development }\end{array}$ & $\begin{array}{l}\text { Collaboration in recent } \\
\text { budgetary policies, which } \\
\text { support productivity enhancing } \\
\text { measures in agriculture such as } \\
\text { fertilizer and seed policies and } \\
\text { fully washed coffee promotion } \\
\text { of the government. }\end{array}$ & $\begin{array}{l}\text { World Bank is supporting this sector } \\
\text { through Rural Sector Support Project } \\
\text { (RSSP), which aims to raise } \\
\text { productivity and incomes among rural } \\
\text { population. }\end{array}$ & \\
\hline $\begin{array}{l}\text { Social sector and community } \\
\text { development. }\end{array}$ & $\begin{array}{l}\text { Development agenda in poverty } \\
\text { reduction and social sectors. }\end{array}$ & $\begin{array}{l}\text { The Bank has supported Rwanda to } \\
\text { improve its social infrastructure after } \\
\text { the genocide especially in the areas of } \\
\text { health, education and HIV/AIDS. } \\
\text { Current poverty reduction support } \\
\text { grants (PRSGs) have been supporting } \\
\text { the social sector. The decentralization } \\
\text { and community development project is } \\
\text { supporting service delivery and } \\
\text { ownership at the local level. }\end{array}$ & \\
\hline
\end{tabular}


Table 2: Status of Active Operations

\begin{tabular}{|c|c|c|c|c|c|c|}
\hline \multirow[t]{2}{*}{ Project } & \multirow[t]{2}{*}{ US\$ mil. } & \multirow[t]{2}{*}{ Objective } & \multirow{2}{*}{$\begin{array}{c}\text { Approval// } \\
\text { Effectiveness }\end{array}$} & \multirow{2}{*}{$\begin{array}{c}\text { Disbursed } \\
\text { as of } \\
\text { Jan '08 }\end{array}$} & \multicolumn{2}{|c|}{ Ratings } \\
\hline & & & & & DO & IP \\
\hline $\begin{array}{l}\text { Rural Water Supply and } \\
\text { Sanitation }\end{array}$ & 21.67 & $\begin{array}{l}\text { To increasing the availability and } \\
\text { sustainability of water supply and sanitation } \\
\text { (WSS) services in rural areas; strengthening } \\
\text { the capacity of communities and agencies, and } \\
\text { mobilize community support. }\end{array}$ & $\begin{array}{c}\text { June 2000/ } \\
\text { January } 2001\end{array}$ & 16.63 & $\mathrm{~S}$ & $\mathrm{~S}$ \\
\hline $\begin{array}{l}\text { Human Resources } \\
\text { Development }\end{array}$ & 37.14 & $\begin{array}{l}\text { To build up Rwanda's human resources and } \\
\text { institutional capacity to deliver education } \\
\text { services. }\end{array}$ & $\begin{array}{c}\text { June 2000/ } \\
\text { January } 2001\end{array}$ & 29.10 & $\mathrm{~S}$ & $\mathrm{~S}$ \\
\hline Rural Sector Support & 55.87 & $\begin{array}{l}\text { To build capacity in the management of } \\
\text { farmed marshland and hillside areas; access to } \\
\text { credit and competitiveness in agricultural } \\
\text { export; and small-scale rural infrastructure. }\end{array}$ & $\begin{array}{l}\text { March 2001/ } \\
\text { October 2001 }\end{array}$ & 46.02 & $\mathrm{~S}$ & $\mathrm{~S}$ \\
\hline $\begin{array}{l}\text { Regional Trade } \\
\text { Facilitation }\end{array}$ & 7.93 & $\begin{array}{l}\text { To improve access to financing for productive } \\
\text { transactions and cross-border trade. }\end{array}$ & $\begin{array}{l}\text { April 2001/ } \\
\text { August 2001 }\end{array}$ & 5.64 & $\mathrm{~S}$ & $\mathrm{~S}$ \\
\hline $\begin{array}{l}\text { Competitiveness and } \\
\text { Enterprise Development } \\
\text { Project }\end{array}$ & 46.15 & $\begin{array}{l}\text { To establish an enabling environment for } \\
\text { private sector-led economic growth and } \\
\text { poverty reduction in Rwanda. }\end{array}$ & $\begin{array}{c}\text { April 2001/ } \\
\text { December 2001 }\end{array}$ & 40.01 & $\mathrm{~S}$ & $\mathrm{~S}$ \\
\hline $\begin{array}{l}\text { Rwanda Demobilization } \\
\text { and Reintegration Project }\end{array}$ & 43.13 & $\begin{array}{l}\text { To help consolidate peace in the Great Lakes } \\
\text { region and foster reconciliation within } \\
\text { Rwanda. }\end{array}$ & $\begin{array}{c}\text { April 2002/ } \\
\text { September } 2002\end{array}$ & 26.58 & $\mathrm{~S}$ & $\mathrm{~S}$ \\
\hline Multi-Sectoral HIV/AIDS & 32.46 & $\begin{array}{l}\text { To strengthen prevention measures in order to } \\
\text { slow down the spread of HIV/AIDS; and } \\
\text { expand support and care for those infected or } \\
\text { affected by HIV/AIDS. }\end{array}$ & $\begin{array}{l}\text { March 2003/ } \\
\text { August } 2003\end{array}$ & 38.09 & $\mathrm{~S}$ & MS \\
\hline $\begin{array}{l}\text { Decentralization and } \\
\text { Community Development }\end{array}$ & 20.53 & $\begin{array}{l}\text { To boost the emergence of a dynamic local } \\
\text { economy, through communities who are } \\
\text { empowered to lead their own development } \\
\text { process under an effective local government. }\end{array}$ & $\begin{array}{l}\text { June 2004/ December } \\
2004\end{array}$ & 11.44 & $\mathrm{~S}$ & $\mathrm{~S}$ \\
\hline $\begin{array}{l}\text { Public Sector Capacity } \\
\text { Building }\end{array}$ & 19.67 & $\begin{array}{l}\text { To ensure that public sector entities have the } \\
\text { capacity for more efficient, effective, } \\
\text { transparent and accountable performance in } \\
\text { their redefined roles and functions and for } \\
\text { achievement of their strategic objectives } \\
\text { contributing to the implementation of the } \\
\text { PRSP }\end{array}$ & July 2004/ & 5.27 & $\mathrm{~S}$ & MS \\
\hline $\begin{array}{l}\text { Urgent Electricity } \\
\text { Rehabilitation }\end{array}$ & 24.13 & $\begin{array}{l}\text { To alleviate power shortages, and enhance the } \\
\text { capabilities of energy sector institutions. }\end{array}$ & January 2005/ & 6.38 & $\mathrm{~S}$ & $\mathrm{~S}$ \\
\hline $\begin{array}{l}\text { Urban Infrastructure and } \\
\text { City Management }\end{array}$ & 21.61 & $\begin{array}{l}\text { To increase access to priority urban } \\
\text { infrastructure in Kigali and two secondary } \\
\text { cities (Ruhengeri and Butare) }\end{array}$ & $\begin{array}{l}\text { November 2005/ } \\
\text { March } 2006\end{array}$ & 8.52 & $\mathrm{~S}$ & $\mathrm{~S}$ \\
\hline $\begin{array}{l}\text { East Africa Trade and } \\
\text { Transport Facilitation }\end{array}$ & 199.53 & $\begin{array}{l}\text { To improve trade environment through the } \\
\text { effective elimination of tariff barriers in the } \\
\text { EAC Customs Union area; enhance logistics } \\
\text { services efficiency along key corridors by } \\
\text { reducing non tariff barriers and uncertainty of } \\
\text { transit time; and improve railway services in } \\
\text { Kenya and Uganda. }\end{array}$ & $\begin{array}{c}\text { January 2006/ } \\
\text { June } 2006\end{array}$ & 54.01 & $\mathrm{~S}$ & MS \\
\hline E-Rwanda & 10.00 & $\begin{array}{l}\text { To improve (i) efficiency and effectiveness of } \\
\text { some internal processes of the Government of } \\
\text { Rwanda, and } \\
\text { (ii) the delivery of services in selected key } \\
\text { sectors, including better access to information } \\
\text { through the use of technology. }\end{array}$ & September 2006/ & 1.5 & $\mathrm{~S}$ & $\mathrm{~S}$ \\
\hline
\end{tabular}




\section{RWANDA: STATISTICAL ISSUES}

Although economic data are generally adequate for surveillance, weaknesses hamper economic analysis. National accounts, prices, government finance, and balance of payments statistics continue to suffer from significant weaknesses. Monetary statistics and data relevant for banking supervision are adequate for program monitoring, but there is some scope for improvements in quality and timeliness. The country has participated in the General Data Dissemination System since October 2003.

In August 2005, the National Institute of Statistics (NIS) was established following the passage of the new Statistics Law.

\section{National Accounts and Price Statistics}

The national accounts are compiled and disseminated by the NIS, based on the 1968 System of National Accounts methodology. Data quality is weak, reflecting inadequate human and material resources. While considerable effort has been made to improve the reliability of GDP estimates using the production approach, significant weaknesses in data collection on expenditures and income hinder assessment of savings and investment. The reliability of national accounts estimates is also reduced by weak external sector statistics.

Since 2003, the East AFRITAC has advised the authorities on real sector statistics issues. This assistance is focused on capacity building to enable the construction of short-term indicators such as a monthly PPI for the manufacturing sector, which is a joint project with the central bank (NBR). The results have not yet been integrated in the national accounts. A DFID project is also supporting the NIS with a component on national accounts, aiming to establish a program of economic surveys and the development of leading indicators that can serve as source data for national accounts. The NIS is working on a new benchmarking of GDP estimates (2001). Work has also advanced in the implementation of the 1993 SNA.

The consumer price index (CPI, 2003=100) utilizes expenditure weights derived from a 2000-01 survey of 6,450 households (local goods account for about 70 percent of expenditure and imported goods about 30 percent; food and drink account for 37 percent of expenditures and housing and energy amount to 16 percent). Certain shortcomings remain, as the CPI aggregates infrequently purchased products in groups with equal weight.

Real sector data are reported regularly for publication in International Finance Statistics $(I F S)$, although with some lag, particularly for GDP estimates. Data on employment and wages are not collected, except for the central government and for daily informal work. 


\section{Government Finance Statistics}

Detailed monthly revenues and expenditures are reported to AFR with a lag of three to four weeks. These data are compiled by the flash-reporting unit of MINECOFIN. A functional classification of government expenditure has been available since the 2003 budget. Within the economic classification, expenditures on PRSP-designated "priority areas" are clearly identifiable. The fiscal data do not capture capital expenditure consistently because capital projects (almost entirely externally financed) are mainly carried out by line ministries outside the regular budget process. Compilation of data on external budgetary assistance as well as on external debt would benefit from strengthened coordination between the finance ministry and the central bank. Efforts are underway to integrate the development budget into the normal budgetary procedures. Fiscal data often exhibit discrepancies between deficit and financing estimates. To address these issues, the authorities have made adjustments for changes in the balance of non-core government accounts, changes in cash in vault at the revenue authority, accounting errors, and other factors.

Selected aggregates on annual central government operations through 2004 have been reported to STA for publication in the IFS, but there are large discrepancies in the data, largely due to the timing of recording of expenditures. No sub-annual data are reported to STA, and government finance statistics (GFS) have not been reported for publication in the GFS Yearbook since 1993.

\section{Monetary Statistics}

The balance sheet of the NBR and detailed data on money market transactions are transmitted to AFR on a weekly basis with a lag of one week, while the monetary survey and the consolidated balance sheet of commercial banks are transmitted on a monthly basis with a lag of about five weeks. Detailed data on interbank money market transactions are also provided upon request. Monetary data used to be reported separately to STA and published in the IFS. The reporting of monetary statistics to STA has been delayed during the migration to the Standardized Report Forms (SRFs) undertaken by the NBR. The interruption in reporting has been longer than initially planned as the progress of the SRF migration has been hampered by the scarcity of skilled staff.

An August 2007 STA mission found that (i) a new chart of accounts for commercial banks was enacted in 2005 and the call report forms sent to the NBR were improved accordingly, thus better reflecting the methodology proposed in the Monetary and Financial Statistics Manual; (ii) the data on the Union des banques populaires du Rwanda - a countrywide mutual bank network - were included in the broad money survey beginning January 2004; (iii) the data on credit and savings cooperatives and other microfinance institutions are still not included in monetary statistics. 


\section{External Sector Statistics}

The balance of payments is affected by weaknesses in the collection of source data (treatment of customs data and bank settlement reports, questionnaires) and insufficient staffing. The June 2003 multisector statistics mission recommended: (1) reorganizing data entry and production of external trade statistics, using ASYCUDA and Eurotrace software; (2) adapting survey forms sent to companies to the BPM5 methodology; and (3) collaborating with Central Public Investments and External Finance Bureau (CEPEX) to obtain data on international and bilateral aid. Subsequently, STA balance of payments statistics missions followed up in January 2004 and June 2005, and AFRITAC missions in October 2006 and June 2007.

Technical assistance also resulted in significant improvements. In particular, the collection of data through direct surveys seems to be well established, and the rate of response is satisfactory (except for embassies). Annual balance of payments and IIP data through 2006 have been reported to STA for publication in the IFS. Also, with the assistance of these missions, the NBR has started compiling BOP/IIP statistics in conformity with international standards.

Some weaknesses remain, particularly in the compilation of trade data. Data compilation was the main focus of the June 2006 AFRITAC mission, and many adjustments to customs data were introduced to improve coverage and valuation. The treatment of bank settlement reports is not effective, because of incomplete automation of the collection of declarations.

The coverage of external aid remains a cause of concern. Data produced by the CEPEX do not include aid from important UN agencies and from certain countries. Only the external aid registered in the Government budget is fully covered. Concerning the other sector, the data should result from the survey on NGOs, but its coverage is insufficient.

Databases on external public debt are maintained by both MINECOFIN and the NBR. A committee, composed of staffs from the ministries of finance and economic planning, foreign affairs, and the NBR, is responsible for collecting, harmonizing, and monitoring information on external public debt. 
Table 3. Rwanda: Table of Common Indicators Required for Surveillance

(As of January 24, 2008)

\begin{tabular}{|c|c|c|c|c|c|}
\hline & $\begin{array}{c}\text { Date of } \\
\text { Latest } \\
\text { Observation }\end{array}$ & $\begin{array}{c}\text { Date } \\
\text { Received }\end{array}$ & $\begin{array}{c}\text { Frequency } \\
\text { of } \\
\text { Data }^{6}\end{array}$ & $\begin{array}{l}\text { Frequency } \\
\text { of } \\
\text { Reporting }^{6}\end{array}$ & $\begin{array}{l}\text { Frequency } \\
\quad \text { of } \\
\text { Publication }^{6}\end{array}$ \\
\hline Exchange Rates & Current & Current & $\mathrm{D}$ & W & M \\
\hline $\begin{array}{l}\text { International Reserve Assets and Reserve } \\
\text { Liabilities of the Monetary Authorities }{ }^{1}\end{array}$ & Current & Current & W & W & M \\
\hline Reserve/Base Money & 05/11/07 & 09/18/07 & W & W & M \\
\hline Broad Money & $03 / 31 / 07$ & 09/08/07 & $M$ & $\mathrm{M}$ & $\mathrm{M}$ \\
\hline Central Bank Balance Sheet & 05/11/07 & 09/18/07 & W & W & M \\
\hline $\begin{array}{l}\text { Consolidated Balance Sheet of the Banking } \\
\text { System }\end{array}$ & 03/31/07 & 08/08/07 & M & M & M \\
\hline Interest Rates ${ }^{2}$ & Sep. 07 & $10 / 26 / 07$ & M & M & M \\
\hline Consumer Price Index & May 07 & $7 / 11 / 07$ & M & M & M \\
\hline $\begin{array}{l}\text { Revenue, Expenditure, Balance and Composition } \\
\text { of Financing }{ }^{3}-\text { General Government }{ }^{4}\end{array}$ & NA & NA & NA & NA & NA \\
\hline $\begin{array}{l}\text { Revenue, Expenditure, Balance and Composition } \\
\text { of Financing }{ }^{3}-\text { Central Government }\end{array}$ & $12 / 31 / 06$ & 07/14/07 & M & M & M \\
\hline $\begin{array}{l}\text { Stocks of Central Government and Central } \\
\text { Government-Guaranteed Debt }\end{array}$ & $12 / 31 / 06$ & 06/31/07 & $A$ & $A$ & $A$ \\
\hline External Current Account Balance & 2006 & $02 / 14 / 07$ & A & SA & A \\
\hline Exports and Imports of Goods and Services & 2006 & $02 / 14 / 07$ & A & A & A \\
\hline GDP/GNP & 2006 & $2 / 22 / 07$ & A & SA & A \\
\hline Gross External Debt & NA & NA & NA & NA & NA \\
\hline
\end{tabular}

${ }^{1}$ Includes reserve assets pledged or otherwise encumbered as well as net derivative positions.

${ }^{2}$ Both market-based and officially-determined, including discount rates, money market rates, rates on treasury bills, notes and bonds.

${ }^{3}$ Foreign, domestic bank, and domestic nonbank financing.

${ }^{4}$ The general government consists of the central government (budgetary funds, extra budgetary funds, and social security funds) and state and local governments.

${ }^{5}$ Including currency and maturity composition.

${ }^{6}$ Daily (D); Weekly (W); Monthly (M); Quarterly (Q); Annually (A); Semi-annually (SA); Irregular (I); Not Available (NA). 
Press Release No. 08/38

FOR IMMEDIATE RELEASE

February 29, 2008
International Monetary Fund

Washington, D.C. 20431 USA

\section{IMF Executive Board Completes Third Review Under PRGF Arrangement with Rwanda and Approves US\$1.8 Million Disbursement}

The Executive Board of the International Monetary Fund (IMF) today completed the third review of Rwanda's performance under a three-year Poverty Reduction and Growth Facility (PRGF) arrangement. The completion of the review allows for the disbursement of SDR 1.14 million (about US\$1.8 million), which would bring total disbursements under the arrangement to SDR 4.56 million (about US\$7.2 million).

In completing the review, the Board also granted a waiver for the nonobservance of a delayed structural performance criterion concerning the publication of the first consolidated report of local governments showing transfers and budget execution per district and per province for the period January-April 2007.

The three-year PRGF arrangement for Rwanda was approved by the Executive Board in June 2006 (see Press Release No. 06/121) in an amount equivalent to SDR 8.01 million (about US\$12.7 million).

The PRGF is the IMF's concessional facility for low-income countries. PRGF loans carry an annual interest rate of 0.5 percent and are repayable over 10 years with a $5 \frac{1}{2}$-year grace period on principal payments.

Following the Executive Board's discussion, Mr. Murilo Portugal, Deputy Managing Director and Acting Chair, said:

"Rwanda's economic performance in 2007 was satisfactory. Economic growth was robust and inflation was contained. Macroeconomic policy implementation was broadly on track, notwithstanding delays in disbursement of donor funds. Structural reforms advanced, albeit with some delays due in part to capacity constraints. 
“The authorities' continued steadfast commitment to reform will be critical, looking forward. The authorities' medium-term policy framework, defined in the new Economic Development and Poverty Reduction Strategy paper, aims to address impediments to growth and poverty reduction while preserving macroeconomic stability. This will require sustaining reform momentum in the social sectors, modernizing agriculture to improve food security, and increasing investment in infrastructure.

"For 2008, the main challenge lies in managing the impact of a grant-financed fiscal expansion without jeopardizing macroeconomic stability. To ensure that the widening of the deficit does not fuel inflation or crowd out credit to the private sector, it is important that the authorities stand ready to make adjustments to the fiscal program as necessary, including by more gradual domestic spending.

"To preserve external debt sustainability, borrowing for large high-priority infrastructure projects needs to be carefully evaluated, and in general, highly concessional borrowing continues to be appropriate. The authorities are encouraged to develop a debt management strategy to guide future borrowing and prevent a re-accumulation of unsustainable debt.

"The authorities' commitment to reforms in the macrocritical areas is welcome. A strong focus is needed on building capacity in the civil service to support public sector reforms. Plans to develop a public financial management action plan are encouraging. The planned reforms in tax administration are essential to mobilize domestic resources and reduce Rwanda's reliance on aid over the long term. Financial sector reform will ensure sound financial management and provide long-term financing for development needs," Mr. Portugal said. 


\section{Statement by Laurean W. Rutayisire \\ Executive Director for Rwanda \\ February 29, 2008}

\section{I - Introduction}

On behalf of my Rwandese authorities, I would like to express our appreciation to Executive Board, Fund management and Staff for their support and continuous policy advice. My Rwandese authorities are also grateful to the international community for its assistance in their efforts to implement needed reforms aiming to achieve strong and sustained growth and alleviate poverty. Under the current Fund-supported program, my authorities have made remarkable progress in maintaining macroeconomic stability and debt sustainability and achieving appreciable economic growth. However, Rwanda as a landlocked country, still dealing with the complex socio-economic aftermath of the 1994 genocide, faces enormous difficulties, owing to the rise in oil prices and very recently compounded by political conflict in Kenya which affects Rwanda's outlet for its exports and imports and an earthquake which struck the great lakes region with a big toll in human lives and infrastructure.

My authorities' implementation of the program supported by the current PRGF has been broadly on track. All quantitative and structural performance criteria for the completion of the third review were met, with the exception of the performance criterion (PC) on the issuance of the first consolidated report of local governments, showing transfers and budget execution per major line items per district and per province for the period from January to April, 2007. The delay was due to capacity constraints, which led to misinterpretation of the PC. As the nonobservance was temporary and given the commitment to meeting the program' s objectives as well as the record of accomplishment, my authorities request a waiver for the nonobservance of the structural PC on the issuance of the consolidated report of local governments.

Mindful of the need to step up their efforts to fight poverty and attain the MDGs, my authorities have successfully launched in November of 2007 their new Economic Development and Poverty Reduction Strategy (EDPRS) indicating the medium-term policy agenda. This agenda aims at reducing poverty, by preserving macroeconomic stability and removing obstacles to sustained economic growth.

\section{II - Recent Economic Developments.}

Economic activity, boosted by investments in construction and services sectors, has continued to be strong in 2007. Real GDP growth is estimated at 6 percent against 5.5 percent in 2006. Inflation has declined to 8.7 percent by November from 12 percent in the beginning of the year and is expected to remain in single digits. The reserve money targets 
were met, but broad money was higher than anticipated. The backloading of fiscal spending to the second half of the year, which injected extra liquidity into the economy during a short period, explained this situation. The exchange rate moderately appreciated against the US dollar. The National Bank of Rwanda has continued selling foreign exchanges in line with the program and has relied on sales of domestic assets in its liquidity withdrawal efforts. In June 2007, the NBR started selling foreign exchange directly to banks at a daily fixed rate, after the abolition of the foreign exchange auctions due to the lack of effective competition.

In the fiscal area, fiscal performance remained broadly on track. Buoyant revenues and expenditure restraint in non-priority areas enabled the authorities to meet all fiscal objectives for the first half of 2007. However, the indicative targets on net credit to the government, domestic fiscal balance, and net accumulation of domestic arrears for endSeptember were missed on account of delays in external disbursements from AfDB and the Fast Track Education initiative, which were received only in the last quarter. Domestic petroleum prices were adjusted periodically to reflect the world oil market developments and the authorities are committed to generating positive revenues from petroleum taxes. In addition, privatization proceeds exceeded expectations with the sale of Rwanda Telecommunications for a total of US\$ 100 million whose part will be used for future infrastructure investment.

As regards structural reforms, substantial progress has been made in several areas. In particular, a progress report on financial reporting by budgetary agencies was published in September and a comprehensive review of the wage structure of the public sector was finalized in October. The poverty profile for the provinces was also produced and it will be extended to districts and communities as soon as the external financing is available. The publication of the consolidated execution report of local governments was done in October instead of July. The legal and regulatory framework for microfinance institutions was submitted to the parliament in June. An insurance bill was also submitted to the Cabinet, while a unit to supervise non-bank financial institutions was established in the NBR. Amendments to the Banking Law were approved by the Parliament in October and the related regulations are under preparation. The AML/CFT bill was approved by the lower chamber of Parliament and has been submitted to the upper chamber for review. A number of measures to reduce the cost of doing business in Rwanda have been introduced. These measures have included the introduction of the Commercial and Registry Services and the Business and Land Registration program.

\section{III - 2008 Program and Medium-Term Agenda}

My Rwandese authorities are fully aware of the critical importance of preserving macroeconomic stability and removing obstacles to growth, in order to fight poverty and attain the MDGs. They are strongly committed to these objectives, which are clearly set out in the new Economic Development and Poverty Reduction Strategy (EDPRS). The main elements of this strategy include enhancing agricultural development and trade; removing obstacles to private sector development; addressing severe infrastructure bottlenecks; improving the delivery of public sector; relying on sustainable financing sources with an emphasis on raising the revenue to GDP ratio in the long-term and 
developing on a pilot basis the grassroots "Umurenge" scheme. In this context, my Rwandese authorities intend to implement in 2008 policies aiming at a real GDP growth of $5.5-6.5$ percent and possibly 7 percent. Inflation will be maintained within single digits, with a level of international reserves of about 4.5 months of imports. On the structural front, efforts will focus on further improving financial management, developing the financial sector in addition to growth-enhancing investments and reforms.

\section{Fiscal Policy}

The fiscal program in 2008 is to further boost productivity and help improve the living standards of Rwandese population. To this end, my authorities intend to pursue prudent management of aid flows consistent with the single-digit inflation objective. This management will also focus on preventing a crowding out of the private sector and building up costly domestic debt. On the revenue front, measures envisaged will aim to increase the revenue-to-GDP-ratio to 13.7 percent, by widening the tax base and improving the efficiency of tax administration on the basis of the recommendations made by the technical assistance benefited from the IMF's Fiscal Affairs Department. In addition, no further tax exemptions will be granted and the existing ones will be carefully managed. On the expenditure side, more resources will be dedicated to public infrastructure and to agriculture, education, health; electricity and water, with a view to meet the important needs in these areas and strengthen the private sector development. The authorities are also strongly committed to continue monitoring the costs associated with the African Union peace keeping in Darfur. The audit report of the spending in 2007 will be published by end-May 2008. A budgetary allocation of about 0.3 percent of GDP is scheduled for the parliamentary elections in 2008 and the military spending will remain at about 2 percent of GDP.

\section{Monetary Policy and Financial Sector Development}

The monetary objective is to contain inflation within a single digit. To this effect, the authorities stand ready to tighten the monetary policy stance and to closely monitor public expenditure and credit to private sector. Furthermore, reserve money growth for the year will be limited to 14 percent. The NBR will continue to sell foreign exchange with a view to mopping up the excess of liquidity. The authorities intend to revitalize the foreign exchange market. In this respect, the forthcoming MCM technical assistance will be helpful in enhancing institutional and human capacity. In order to further strengthen liquidity management, the authorities intend in 2008 to introduce four week instruments and establish repurchase agreement operations ranging from 1 to 90 days. The authorities are also committed to formalizing the existing Treasury Management Committee (TMC) as an analytical platform to coordinate and refine the implementation and forecast of fiscal and monetary policies. In addition, the conversion of the Union des Banques Populaires du Rwanda (UBPR) from a microfinance network to a commercial bank will be completed in the first quarter of 2008.

\section{Structural Reforms and Competitiveness}

The structural reform agenda will focus on pursuing efforts to improve the conditions for the private 
sector, enhance the productivity of the agricultural sector and expand the export base. In this context, momentum of reforms in the financial sector, tax administration and public financial management will be maintained. As for public finance management, the authorities intend to develop a new medium-term PFM action plan to update the framework needed to implement specific reform measures, guide the mobilization of resources and improve coordination and sustainability of the reforms. On the export side, Rwanda's Free Zone Company Ltd was established to fast track the implementation of the Export Processing Zone (EPZ).The authorities intend also to develop with the assistance of the World Bank a master plan for the development of the tourism sector which attracts substantial inflows of FDI.

Other structural reforms designed to create an environment conducive to private sector development include the modernization of the national payments system and the creation of capital market to develop long-tern finance. With regard to the payment system, the National Payment Council will be established by-June 2008. The authorities plan to inaugurate by the first quarter of 2008 a government bond market which will be followed by the establishment of a corporate bond market. They also plan to enact a Private pension and Mutual Fund law to further strengthen the legal and regulatory framework in order to support the development of a market for the contractual savings industry and long-term saving and investment instruments. To reduce the cost of doing business, the Rwanda Commercial and Registry Services will be made operational in providing a comprehensive registration system aimed at improving business registration, securization of assets and registration of intellectual property rights.

\section{Debt Sustainability}

The debt sustainability analysis concludes that Rwanda remains at a high risk of debt distress, owing to its small export base with or without borrowing for the large infrastructure project. My authorities are of the view that given the country's export potential if the infrastructure projects are implemented notably in the energy, agricultural and ICT sectors, there will be a substantial improvement in the debt indicators. However, to prevent the reaccumulation of unsustainable debt, my authorities will develop a debt management strategy to guide future borrowing. 


\section{Poverty reduction}

My Rwandese authorities are strongly determined to pursue the fight against poverty. In this regard, they have completed and published the second PRSP, which has been elaborated through a participatory process and endorsed by all stakeholders. This new PRSP will be a guiding tool for the elaboration of fiscal policy and provision of international support to Rwanda.

\section{IV - Conclusion}

My Rwandese authorities have implemented under the current PRGF-supported program sound policies and reforms, while achieving remarkable performance. However, there remain a number of challenges to overcome, in order to sustain higher economic growth and make substantial inroads in poverty alleviation. My authorities are committed to step up their efforts with the continued support of the international community. Given the authorites'achievements under the program and their commitment to achieve the program objectives, I would like on their behalf to request the Board approval for the waiver of the performance criteria as the nonobservance was temporary and the completion of the third review of the PRGF arrangement. 